\title{
Fluids and Ore Formation in the Earth's Crust
}

\section{Book Chapter}

Author(s):

Heinrich, Christoph A. (D); Candela, Philip A.

Publication date:

2014

Permanent link:

https://doi.org/10.3929/ethz-b-000095425

Rights / license:

Creative Commons Attribution-NonCommercial-NoDerivatives 4.0 International

Originally published in:

13, https://doi.org/10.1016/B978-0-08-095975-7.01101-3 
This is the Green Open Access version of: Heinrich C.A., and Candela P.A. (2014) Fluids and Ore Formation in the Earth's Crust. In: Holland H.D. \& Turekian K.K. (eds.) Treatise on

Geochemistry, 2nd Edition, vol. 13 (Geochemistry of Mineral Deposits, S. D. Scott, ed.), p. 1-28.

Original publication see http://dx.doi.org/10.1016/B978-0-08-095975-7.01101-3

\section{Fluids and Ore Formation in the Earth's Crust}

Christoph A. Heinrich ${ }^{1}$ and Philip A. Candela ${ }^{2}$

1 ETH Zurich, Department of Earth Sciences, and University of Zurich, Faculty of Mathematics and Natural Sciences, Clausiusstr. 25, 8092 Zurich, Switzerland

2 Laboratory for Mineral Deposits Research, Department of Geology, University of Maryland, College Park, MD,20742, USA

\section{Synopsis}

Ore deposits are rock volumes containing selected elements in sufficient concentration and quantity that they can be extracted economically. Except for Fe and $\mathrm{Al}$, all technically important metals and other elements are scarce, in total constituting less that $1 \%$ of the Earth's crust. Depending on the element and its mineralogy, a 10- to 10,000-fold enrichment is required for economic extraction today. Such extreme element concentration involves a combination of processes operating in concert, which explains why ore deposits have similar characteristics but are relatively rare.

Selective element enrichment generally includes steps of (1) dissolution of elements from common crustal or mantle rocks, (2) physical transport by a mobile phase such as a melt or an aqueous fluid, and (3) chemical precipitation in distinct minerals forming the ore deposit. Element transport by hydrothermal fluid, i.e., a water-rich agent that can flow through permeable and commonly fractured rocks, is particularly efficient and chemically selective. The processes contributing to the broad range of hydrothermal ore deposits are the main theme of this introduction, but magmatic and surface deposits are introduced to illustrate the common principles of ore formation.

Keywords Ore deposit, mineral deposit, hydrothermal, fluid, geochemistry

\section{Glossary}

A mineral deposit is any anomalous accumulation of minerals and chemical elements contained in them. The term ore deposit is reserved here for a mineral deposit in which grade (bulk concentration of valuable elements) and the quantity of ore (the tonnage of a deposit) allows extraction of one or several elements for profit, at current economic and technical conditions.

Fluid is used here for a low-viscosity mobile phase that has a density much smaller than that of silicate materials; such fluids are usually dominated by volatile components including $\mathrm{H}_{2} \mathrm{O}$ plus various species of $\mathrm{C}, \mathrm{S}$ and $\mathrm{Cl}$ salts. Hydrothermal specifies a fluid heated by Earth's interior energy to a temperature exceeding $50^{\circ} \mathrm{C}$.

Liquid and vapor (equivalent to liquid water and steam in the pure $\mathrm{H}_{2} \mathrm{O}$ system) are two types of hydrothermal fluids that can exist individually, or may stably coexist as distinct phases in contact with each other. Vapor (gas) will homogeneously fill any available volume and is generally of lower density and enriched in gas-like components including $\mathrm{CO}_{2}, \mathrm{CH}_{4}$ or $\mathrm{H}_{2} \mathrm{~S}$, whereas a liquid is denser and commonly enriched in chloride, sulfate or carbonate salts of $\mathrm{Na}, \mathrm{K}, \mathrm{Ca}, \mathrm{Fe}$ and other cations. More rigorous definitions are proposed in Liebscher and Heinrich (2007). 
Melts dominated by silicate, sulfide, carbonate, oxide and borate components are distinguished in this paper, using the respective qualifiers, even though they are also 'fluids' in the physical sense and are key to selective element enrichment in magmatic ore deposits (discussed in greater detail by Mungall, this volume).

\section{Ore Deposits and Crustal Geochemistry}

\section{Ores, Mineral Deposits and Crustal Composition}

Ten elements (O, Si, Al, Fe, Ca, Mg, Na, K, Ti and $\mathrm{H}$ ) make up approximately $99.6 \%$ of the Earth's continental crust by mass (Rudnick and Gao, 2003). All other industrially important elements can be considered as scare, making up a small fraction of the remaining $0.4 \%$ with concentrations of less than $1000 \mathrm{ppm}(\mu \mathrm{g} / \mathrm{g})$ each. They range from vital elements such as phosphorus and manganese at hundreds of ppm, to precious metals at parts per billion levels in average continental crust. Variations in the major element composition among crustal rocks are manifested in the proportions of rock-forming minerals and common accessory phases, and most of the scarce elements are normally accommodated in the crystal structure of these minerals. Economically viable and energy-efficient extraction of such elements for industrial use requires specialized rocks, in which one or several valuable elements are selectively enriched and usually occur as separate mineral phases. If such geochemical and mineralogical anomalies are large and rich enough to be mined for a profit, they are called ore deposits (Skinner, 1997). The geological processes leading to the formation of ore deposits are introduced in this chapter and represent the theme of this new volume of Treatise on Geochemistry.

The scarce elements form positive anomalies with varying efficiency. To a first order, the behavior of scarce elements is controlled by the extent to which their crystal-chemical behavior differs from that of the major elements in rock-forming minerals, i.e., to which extent they enter into solid solution in common silicates (feldspars, pyroxene, amphibole, micas, clay minerals, quartz), carbonates, oxides (e.g. magnetite) and sulfides (pyrite, pyrrhotite). Some scarce elements can be enriched to economic degrees in solid solutions of major rock-forming minerals (e.g., $\mathrm{Rb}$ and $\mathrm{Li}$ in micas or $\mathrm{V}$ in magnetite) and some are selectively incorporated in accessory minerals of common rocks (e.g. zirconium and minor hafnium in zircon; REE in monazite). However, many elements such as base metals $(\mathrm{Cu}, \mathrm{Pb}$, $\mathrm{Zn}$ ), semi-metals (As, $\mathrm{Sb}, \mathrm{Bi}$ ), precious metals ( $\mathrm{Au}, \mathrm{Ag}$, platinum-group elements) and many more (e.g., Mo, Re, In, Ge, Hg) do not have a strong affinity for minerals that constitute the bulk of the crust. They are excluded from all but the most limited solid solution in rockforming minerals. These elements tend to partition into less-ordered phases including fluids (aqueous solutions, salty brines, vapor) or melts (silicate melts, but also sulfide, carbonate or even borate melts). Such phases are also physically mobile and therefore allow selective element transport and local precipitation of scarce elements as separate mineral phases, such as sulfides containing $\mathrm{Cu}, \mathrm{Pb}$ or $\mathrm{Zn}$ as a major stoichimetric component.

Ore-forming processes operate at a minimum scale defined by the size of ore deposits and the degree of element enrichment needed for their economic utilization. Table 1 shows a selection of elements, ordered by decreasing average crustal abundance, in comparison with the typical concentration in large ore deposits mined today (ore grade). Besides the enrichment factor (the so-called Clarke value $=$ ore grade $/$ average crust), the table also shows the size (in tonnes of ore) of one of the largest ore deposits of each type. For example, the Muruntau gold deposit contains a total of $5300 \mathrm{t}$ of $\mathrm{Au}$, mineable at a grade of $\sim 2.4 \mathrm{ppm}$ from a rock volume with a network of numerous veins that precipitated from hydrothermal fluids (Wall et al., 2004; Goldfarb et al., 2005). Gold is enriched by a factor of $\sim 2000$, compared to average crustal abundance of $1.3 \mathrm{ppb} A u$. Multiplying the ore tonnage with the enrichment factor yields $4 \cdot 10^{12}$ tonnes of average crustal rocks, or approximately $1400 \mathrm{~km}^{3}$ 
of average crust, from which all its $1.3 \mathrm{ppb}$ Au would have to be extracted and accumulated in this deposit. No process of extraction and ore-deposition is $100 \%$ efficient, of course, indicating that the ore-forming process has probably operated within an even larger region of the crust and possibly the underlying mantle.

\begin{tabular}{|c|c|c|c|c|c|c|c|}
\hline \multirow[b]{2}{*}{ Element } & \multicolumn{6}{|c|}{$\begin{array}{l}\text { Table } 1 \text { - Typical mineable ore grades of selected elements in comparison with their average crustal abundance } \\
\text { Tonnage (total mass of mined and economically mineable ore) and average grade of some of the largest ore deposits of each type }\end{array}$} & \multirow[b]{2}{*}{ Grade } \\
\hline & Deposit type & $\begin{array}{l}\text { Typical ore grade } \\
(\mathrm{ppm}=\mathrm{g} / \mathrm{t})\end{array}$ & $\begin{array}{l}\text { Concentration } \\
\text { in crust }(\mathrm{ppm})\end{array}$ & $\begin{array}{l}\text { Enrichment } \\
\text { factor }\end{array}$ & Largest Deposits & Tonnage & \\
\hline $\mathrm{Fe}$ & Banded Iron Formation, upgraded & 640,000 & 52,200 & 12 & Mount Whaleback (Australia) & $>1800 \mathrm{Mt}$ & $65.0 \%$ \\
\hline Al & Lateritic bauxite & 240,000 & 84,200 & 3 & Weipa, (Austarlia) & $149 \mathrm{Mt}$ & $28 \%$ \\
\hline $\mathrm{Ti}$ & Mafic intrusions (ilmenite, Lac Tio) & 80,000 & 5700 & 14 & Lac Tio (Canada) & $>125 \mathrm{Mt}$ & $25 \%$ \\
\hline $\mathrm{P}$ & Marine sedimentary deposits & 100,000 & 570 & 180 & Meade Peak Member (USA) & $>10^{11} \mathrm{Mt}$ & $10 \%$ \\
\hline $\mathrm{v}$ & Layered mafic intrusions (magnetite) & 2,000 & 138 & 14 & Bushveld Complex (South Africa) & $50 \mathrm{Mt}$ & $0.8 \%$ \\
\hline $\mathrm{Cr}$ & Layered mafic intrusions (chromite) & 160,000 & 135 & 1,200 & Bushveld Complex (South Africa) & $2700 \mathrm{Mt}$ & $19 \%$ \\
\hline $\mathrm{Zn}$ & Stratiform $\mathrm{Pb}-\mathrm{Zn}-\mathrm{Ag}$ deposits & 87,000 & 72 & 1,200 & Broken Hill (Australia) & $284 \mathrm{Mt}$ & $11 \%$ \\
\hline $\mathrm{Ni}$ & Magmatic $\mathrm{Ni}$-Cu sulfide deposits & 13,000 & 59 & 220 & Jinchuan, Bajiazuizi (China) & $515 \mathrm{Mt}$ & $1.1 \%$ \\
\hline $\mathrm{Rb}$ & Pegmatites, from Rb-bearing Lepidolite & 5,000 & 49 & 100 & Tanco (Canada) & $0.5 \mathrm{Mt}$ & $1.0 \%$ \\
\hline $\mathrm{Cu}$ & Porphyry copper deposits & 5,000 & 27 & 180 & El Teniente (Chile) & $2850 \mathrm{Mt}$ & $1.3 \%$ \\
\hline $\mathrm{Cu}$ & Sediment-hosted copper deposits & 23,000 & 27 & 850 & Lubin (Poland) & $2600 \mathrm{Mt}$ & $2.0 \%$ \\
\hline $\mathrm{Pb}$ & Stratiform Pb-Zn-Ag deposits & 47,000 & 11 & 4,300 & Broken Hill (Australia) & $160 \mathrm{Mt}$ & $10.0 \%$ \\
\hline $\mathrm{Nb}$ & Carbonatites & 1,900 & 8 & 240 & Seis Lagos (Brazil) & $2898 \mathrm{t}$ & $2 \%$ \\
\hline Eu & Carbonatites & 1,300 & 1.1 & 1,200 & Bayan Obo (China) & $750 \mathrm{Mt}$ & $4.1 \% *$ \\
\hline w & Skarn, replacement and vein deposits & 3,300 & 1 & 3,300 & Shizhuayan (Skarn, China) & $270 \mathrm{Mt}$ & $0.22 \%$ \\
\hline Mo & Porphyry molybdenum deposits (Climax) & 2,000 & 0.8 & 2,500 & Climax (Colorado, USA) & $769 \mathrm{Mt}$ & $0.22 \%$ \\
\hline Ta & Pegmatite (Tanco, Canada) & 1,800 & 0.7 & 2,600 & Tanco (Canada) & $2.07 \mathrm{Mt}$ & $0.18 \%$ \\
\hline $\mathrm{Ag}$ & Polymetallic vein deposit (Cerro Rico) & 160 & 0.056 & 2,900 & Cerro Rico de Potosi (Bolivia) & $985 \mathrm{Mt}$ & $116 \mathrm{~g} / \mathrm{t}$ \\
\hline In & Volcanic-hosted massive sulfide deposits & 24 & 0.052 & 500 & Kidd Creek (Canada) & $134 \mathrm{Mt}$ & $50 \mathrm{~g} / \mathrm{t}$ \\
\hline $\mathrm{Hg}$ & Epithemal veins and breccias (Almaden) & 10,000 & 0.030 & 300,000 & Almaden (Spain) & $40 \mathrm{Mt}$ & $>1 \%$ \\
\hline $\mathrm{Pt}$ & Magmatic PGE - Ni - Cu sulfide deposits & 3 & 0.0015 & 2,000 & Bushveld Complex (South Africa) & $9815 \mathrm{Mt}$ & $2.3 \mathrm{~g} / \mathrm{t}$ \\
\hline $\mathrm{Au}$ & Hydrothermal vein deposits & 2 & 0.0013 & 1,200 & Muruntau (Uzbekistan) & $2200 \mathrm{Mt}$ & $2.4 \mathrm{~g} / \mathrm{t}$ \\
\hline $\mathrm{Au}$ & Modified Archaean Placer (Witwatersrand) & 5 & 0.0013 & 4,000 & Witwatersrand Basin (South Africa) & $>10^{4} \mathrm{Mt}$ & $5 \mathrm{~g} / \mathrm{t}$ \\
\hline \multicolumn{6}{|c|}{ All values in weight units. Average concentration in crust from Rudnick and Gao (2003, Tab. 11, total crust) } & \multicolumn{2}{|c|}{ *SUm REE oxides } \\
\hline \multirow{2}{*}{\multicolumn{8}{|c|}{$\begin{array}{l}\text { Estimates of average grades indicative only, mostly based on USGS and Canadian Geological Survey compilations but partly representing single big deposits } \\
\text { Grades and tonnages of some of the largest deposits mostly represent single mines, but in case of the Meade Peak phosphorite, the Bushveld Complex, }\end{array}$}} \\
\hline & & & & & & & \\
\hline & Witwatersrand Basin are estimates for on & & its that are $\mathrm{mi}$ & & esently economic ore grades for the $\mathrm{r}$ & & lements \\
\hline
\end{tabular}

Mass balance imposed by enrichment factors and deposit dimensions bears two important conclusions for the scale and process of ore formation (indeed, similar calculations can be made with similar results for most other scarce elements and ore types). First, the physical size of regions of the Earth's crust in which an ore-forming process operates must be large, many orders of magnitude larger than the size of the small and seemingly anomalous rock volumes constituting economic ore deposits. Understanding ore formation therefore requires understanding ore forming systems, i.e., regions in the crust typically extending over tens to hundreds of kilometers in lateral extent and perhaps down to mantle depths, in which scarce metals are selectively redistributed. Second, the scale of ore systems makes it physically impossible that the formation of an economic ore deposit occurs by element diffusion through any stagnant material, which at best extends over a characteristic distance of $<100$ meters on a time scale of $\sim 1 \mathrm{~m} . \mathrm{y}$. (for aqueous fluid at $\mathrm{T}<600^{\circ} \mathrm{C}$; solid diffusion would allow at most $\sim 10 \mathrm{~mm}$; Watson and Baxter, 2007).

All ore-forming systems therefore combine chemical reactions with physical transport: selective dissolution and precipitation of minerals are linked with large-scale advective transport of a mobile phase through rocks. The diversity of fluids and melts, the range of physical driving forces for transport, and the specific crystal-chemical controls on mineral dissolution and precipitation account for the wide range of ore-forming processes, leading to distinct but globally recurrent ore deposit types. This paper aims to introduce this diversity, while emphasizing the common principles.

\section{Economic Aspects: Deposit Assessment, Grade and Reserves}

Before introducing the range of major processes conspiring to generate ore deposits, we will illustrate some important economic terms. They touch on the global issue of future availability of raw materials, but they also show the geochemical significance of ore deposits in the crust. The economic assessment of an ore deposit always has a historical perspective, 
determined by the changing value of materials to society and the changing technology of extraction and further beneficiation of metals from natural ore. Therefore, definitions of economic terms including ore deposit types, ore grades, reserves and resources are subject to change over time, and predictions for future availability require in-depth geological understanding (Kesler, 1994; Singer, 2010).

Ore grade and tonnage. Element concentrations in the Earth's crust show a broadly lognormal distribution, extending from 'ordinary' rocks through element anomalies and subeconomic mineral deposits, to economic ore deposits (Shen and Zhao, 2002). Ore grade denotes the average element concentration contained in one or several orebodies making up a deposit. The mass of rock, calculated to be extractable at an economic profit, is called the tonnage of an ore deposit. Grade and tonnage were initially used by Lasky (1950) to show the inverse relationship between average grade and tonnage of porphyry copper deposits. Statistical analyses show that the few largest deposits of each metal contain the greatest proportion of potentially economic ore (Singer, 1995; Singer et al., 2005). Kesler and Wilkinson (2008) estimated that only about $0.08 \%$ of the total copper contained in the continental crust is concentrated in discovered and still undiscovered deposits of currently economic grade and size. This estimate is based on modeling the known frequency of porphyry copper deposits in terms of time-dependent tectonic diffusion, i.e., a random chance of tectonic burial, or uplift and recycling by erosion, after formation of each deposit at an average depth known from geological studies. Both calculations show that ore deposits are geochemical amomalies and do not contribute significantly to the bulk inventories of any element in the Earth's crust. Mining correspondingly occupies a vanishingly small proportion of the Earth's surface.

Reserves and resources are two distinct economic terms of great geochemical as well as economic interest (Kesler, 1994; Pohl, 2011). The term reserve applies, for an individual deposit or for the global reserves of a metal, to the total metal quantity that is known to be extractable in the present economic situation. By contrast, resources are subject to lower degrees of certainty or are sub-economic at the time. As new and innovative technologies of mining and metal extraction are developed, and as exploration improves the level of knowledge about metal distribution in the crust, subeconomic mineral deposits are turned into economic ore deposits. Thus, new metal reserves become available for use. The conversion of resources into reserves by geological exploration explains the apparent paradox that global reserves of copper and other essential metals have continually increased over the last decades, even though these effectively non-renewable commodities have been intensely extracted and reserves of individual mines have been depleted in the same period (Tilton and Lagos, 2007). Generally, element resources for future use are not so much limited by availability, but by increasing economic, environmental and energy costs of extracting them from lower-grade ores.

The economic importance of multiple elements that are enriched in certain ore deposit types has been subject to historic change, in light of changing metal utilization and technology. This is illustrated by uranium - vanadium deposits (Candela, 2003), as one of many examples. Vanadium and uranium are enriched together because the share the chemical property of being highly soluble in oxidized form ( $\mathrm{U}^{6+}$ and $\mathrm{V}^{5+}$ aqueous complexes), but precipitate as oxide and silicate minerals upon reduction $\left(\mathrm{V}^{3+}\right.$ in vanadiferous magnetite and silicates, $\mathrm{U}^{4+}$ in uraninite $\sim \mathrm{UO}_{2}$ ) when fluids contact carbonaceous material. From 1912 to 1922, the sandstone-hosted uranium deposits on the Colorado Plateau were the first major sources for radium for medical use, but then became vanadium mines from 1924 to 1945 (Fitch, 1997). Uranium and its daughter isotopes were discarded as part of the vanadium mine tailings, but from 1947 these tailings became a source for much of the uranium used for atomic weapons. The use of uranium for nuclear power plants further increased demand in the early 1950's, so that the former vanadium deposits became uranium deposits producing vanadium as a by-product. Many deposits contain about ten 
times more vanadium than uranium, so geochemically, uranium could be considered a byproduct of vanadium mining. When the demand for uranium dropped and rising worldwide steel production increased demand for vanadium in the late 1990's, many sandstone uranium deposits turned again into vanadium-(-uranium) mines. Similar changes affected sulfide deposits, in which lead or silver were the most valuable products from medieval times (roofing, coins) to the early industrial age (car batteries, leaded fuel), until environmental considerations and the advent of protective coating of steel turned many lead deposits into dominant zinc resources.

These examples show that we must be careful how to interpret economic information about ore deposits in terms of its geochemical significance. On the other hand, the examples also emphasize the practical importance of understanding metal enrichment more quantitatively. Such understanding is essential to predict, for example, the distribution and reserves of particularly valuable ore deposits containig a high proportion of $\mathrm{Zn} / \mathrm{Pb}$, despite the geochemical similarity of these two metals.

\section{Extreme Metal Enrichment: A Conjunction of Processes}

Ore deposits are rare because extreme element enrichment requires a conjunction, spatially and temporally, of physical transport processes and selective chemical reactions between minerals and fluids or melts. We think that the complexity in this field of geoscience, with numerous deposits being termed 'unique' in the specialist literature, can be broken down by understanding the interactions between otherwise common and quite predictable processes. These processes can be rationalized by three factors, (1) the type of medium allowing selective component transport, (2) global-scale tectonic drivers from the Earth's interior, and (3) interactions of endogenous processes with the atmosphere, which has been subject to changing climate and oxygen levels through Earth's history (Robb, 2004).
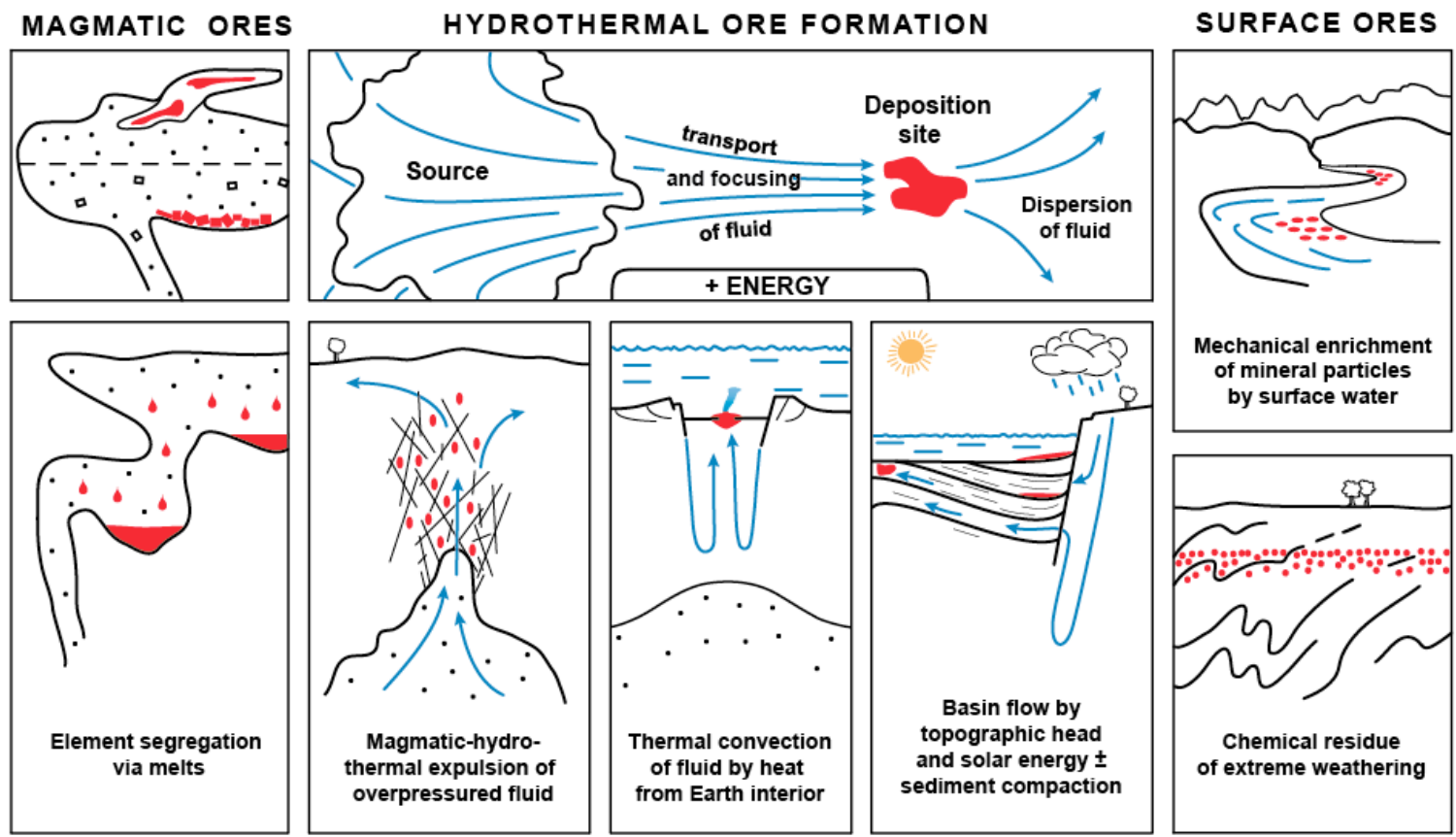

Fig. 1: Schematic illustration of three principal processes of selective element enrichment that can produce mineral deposits in the Earth's crust, grouped by the main agent of selective material transport, i.e., magmatic melts (left), hydrothermal fluids of variable origin and driven by different energy sources (center) and surface water acting as a chemical or mechanical transport agent (right). Modified from Kesler (1994).

The nature of the mobile phase for selective element transport yields a first subdivision of ore-forming processes (Fig. 1). Thus, we distinguish magmatic ore deposits in which 
element separation is primarily effected by silicate, sulfide or carbonatite melts. Hydrothermal ore deposits, in the widest sense of the term, are metal enrichments by selective dissolution of mineral components in a fluid allowing large-scale transport and physical focusing into a smaller volume of permeable rock, followed by selective precipitation of metal-rich minerals into primary or secondary pore space (Barnes, 1997). Surface water can generate important ore deposit types by the converse process of selective removal of rock material at the Earth surface (residual ores), either by chemical dissolution or mechanical winnowing, such that a valuable element becomes enriched in the solid residue (Fig. 1, right).

The subdivision into magmatic, hydrothermal and surface processes provides a framework for the genetic classification of major ore deposit types, as summarized in Table 2 and illustrated by characteristic ore-related textures in Figure 2. Table 2 illustrates that most elements are selectively enriched in only one or a few of these major ore types, ultimately reflecting the crystal-chemical properties of each element. Some deposit types are transitional in origin, e.g. sedimentary manganese and banded iron formations, which are precipitated from seawater after low-temperature interaction with rocks at the ocean floor or enrichment by metals from hydrothermal black smokers. Other deposits form by superposition of processes, for example the secondary enrichment of copper in supergene orebodies by weathering of primary hydrothermal copper deposits. Grains of gold or cassiterite $\left(\mathrm{SnO}_{2}\right)$ that were deposited originally by hydrothermal solutions, can be accumulated in alluvial gravels after erosion of the primary deposits, forming secondary placer deposits (Fig. 2A).

Global tectonics is the second major factor in the formation of distinct ore deposit types and a key to understanding their spatial and secular distribution (Groves et al., 2005; Holland, 2005; Fig. 3). Thus, chromium deposits form by physical accumulation of what is usually an accessory mineral (chromite, $\mathrm{FeCr}_{2} \mathrm{O}_{4}$ ) from large reservoirs of mafic magma (Fig. 2F). Such magma chambers either form as intraplate layered intrusions (possibly related to mantle plumes) or at spreading axes in the oceanic domain (Stowe, 1994). Porphyry copper deposits are generally related to subduction zones, because their formation depends on magmatic volatiles that had previously contributed to partial melting of hydrated mantle above a descending hydrous slab (Hedenquist and Lowenstern, 1994; Sillitoe, 2010). A temporal clustering of gold deposit formation during the Late Archean, Paleoproterozoic and the Phanerozoic is thought to be related to three periods of particularly rapid crustal growth (Goldfarb et al., 2005; Bierlein et al., 2006), although the age distribution is also affected by recycling of Archean gold and preferred preservation in younger orogens (Frimmel, 2008). The formation of sediment-hosted lead - zinc deposits requires large-scale flow of saline fluids through stable aquifers, which can be effected in shallow-marine intracontinental basins experiencing transient uplift of the basin margin as a result of continental collision (Bethke, 1986; Garven et al., 1993).

Figure 2: Textures of ore samples and related fluid processes, recording characteristic time relations between mineral precipitation and the interaction of fluids and melts, ranging from the near-surface environment $(A, B)$ through hydrothermal processes $(C, D)$ to magmatic settings $(E, F)$. All scale bars 1 $\mathrm{cm}$. A: Archean quartz - pyrite pebble conglomerate enriched in alluvial gold and uraninite by flowing surface water (prior to partial metamorphic recrystallization; Witwatersrand Basin, South Africa). B: Stratiform Pb-Zn sulfide ore showing evidence of sedimentary (crossbedding) to early-diagenetic (birdseye textures) precipitation of galena and spalerite (HYC deposit, McArthur River, Australia). C: Missisippi Valley-type Pb-Zn ore in brecciated dolomite cemented by successive crystal layers of markasite, spalerite, galena and final vug-filling calcite (Pillara deposit, Canning Basin, Australia). D: Orogenic gold - quartz vein cutting Archean dolerite, where sulfur-rich fluids converted ferromagnesian silicates to a bleached alteration halo of auriferous pyrite + albite + muscovite + ankerite (Mt. Charlotte mine, Golden Mile, Kalgoorlie, Australia). E: Miarolitic granite showing textural evidence of the separation of a magmatic fluid phase during crystallization of silicate magma, which may give rise to later hydraulic fracturing and magmatic-hydrothermal Sn, W or Cu ore deposition (Ruby Creek Granite, 
Stanthorpe, Australia). F: Magmatic chromite ore showing graded interbedding of olivine-rich (green) and chromite-rich (black) cumulate layers that settled out of a basaltic silicate melt (Troodos ophiolite, Cyprus).
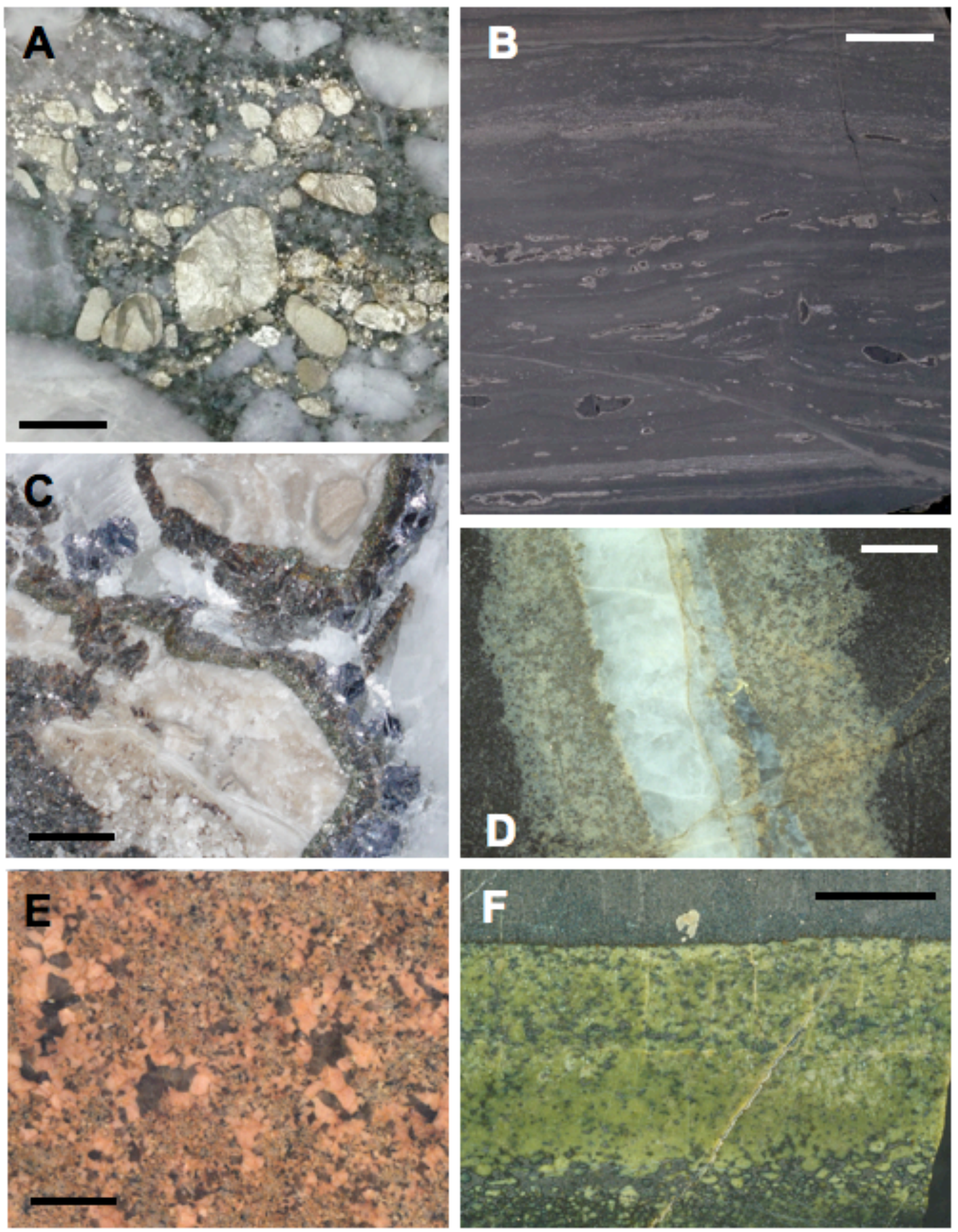
Table 2. Major ore deposit types of elemental (mostly metal) resources grouped according to three major modes of element transport (Fig. 1)

and further subdivided according to dominant fluid sources and characteristic geodynamic environments (Fig. 3)

\begin{tabular}{|c|c|c|c|}
\hline Crystallisation from magma & $\begin{array}{l}\text { Chromitites as (ultra-)mafic cumulates (Mungall) } \\
\text { V-magnetite, ilmenite in mafic intrusions (Mungall) }\end{array}$ & $\begin{array}{l}\mathbf{C r}(\mathrm{Pt}, \mathrm{Pd}) \\
\mathbf{V} ; \mathrm{Ti}\end{array}$ & $\begin{array}{l}\text { RSA, India, Khazakstan } \\
\text { Can, RSA, Russia }\end{array}$ \\
\hline $\begin{array}{l}\text { Sulphide melt segregates } \\
\text { from silicate melt }\end{array}$ & $\begin{array}{l}\text { Magmatic sulfides in mafic intrusions \& flows } \\
\text { Chalcophile precious-metal deposits (Mungall) }\end{array}$ & $\begin{array}{l}\text { Ni, } \mathrm{Cu}(\mathrm{Pt}, \mathrm{Pd}) \\
\mathbf{P t}, \mathbf{P d}, \mathbf{R h}, \mathbf{I r} . .(\mathrm{Au})\end{array}$ & $\begin{array}{l}\text { Canada, Russia, Aus } \\
\text { RSA, Russia }\end{array}$ \\
\hline $\begin{array}{l}\text { Low-degree patial melting } \\
\text { of mantle }\end{array}$ & $\begin{array}{l}\text { Carbonatites (Mungall; Linnen) } \\
\text { Kimberlite, Lamproite (Mungall) }\end{array}$ & $\begin{array}{l}\text { REE, Nb, Ta Zr, P } \\
\text { Diamond }\end{array}$ & $\begin{array}{l}\text { China, RSA, USA } \\
\text { RSA, Canada, Russia }\end{array}$ \\
\hline Extreme granite fractionation & Rare-element pegmatites (Linnen;Groat) & $\mathbf{L i}, \mathbf{B e}, \mathbf{N b}, \mathbf{T a}$, gems & Bras, Can, Russia \\
\hline
\end{tabular}

\section{B. Hydrothermal ore deposits: Enrichment by selective dissolution, transport and precipitation from aqueous fluids of different sources}

Fluid-saturation of

$\mathrm{H}_{2} \mathrm{O}$-bearing magmas:

Magmatic-hydrothermal

Continental geothermal systems ( \pm shallow magmatic fluids)

Continental evaporite brines heated by magmatism \pm magmatic fluids

Seawater \pm magmatic fluid convection through oceanic crust and submarine volcanoes

Metamorphic dehydration

\pm deep magmatic fluids

\pm basin fluid interaction

Connate or evaporite-derived basin brines flowing through sedimentary \pm underlying basement rocks

Deep infiltration of oxygenated surface waters
Porphyry deposits ('Cu-Mo-Au porphyries') (Cooke) Sn-W-veins and replacement deposits (Linnen) Skarn-deposits (calc-silicate replacement; Meinert)

Epithermal veins und hydrothermal breccias (Saunders; Kissin)

Iron Oxide Cu-Au (-U-REE) deposits (Barton) ('IOCG') deposits

Volcanogenic massive sulfide deposits (Hannington) 'black smoker' systems and older equivalents

Orogenic ('metamorphogenic') gold deposits in Archean greenstones \& young orogens (Spry, Saunders) Carlin-type gold deposits in sediments (Saunders)

Sediment-hosted $\mathrm{Cu} \pm$ Co deposits (Brown) Stratiform Pb-Zn-Ag-deposits (,sedex'; McGoldrick) ('sedex' = sedimentary-exhalative, early-diagenetic) Mississippi Valley-type (MVT) Pb-Zn epigenetic replacement in carbonates \pm sandstones (McGoldrick) Five-Element Silver Veins (Kissin)

Sandstone uranium deposts ('roll-front'; Kyser) Vein- and unconformity-related $\mathbf{U}$ deposits (Kyser)
$\mathrm{Cu} ; \mathrm{Mo} \mathrm{Au}$ $\mathrm{W}, \mathrm{Cu}, \mathrm{Au}$

Chile, USA

Russia, China, Bolivia

China (W - scheelite)

$\mathrm{Au}, \mathrm{Hg}(\mathrm{Ag}, \mathrm{Pb}, \mathrm{Zn}) \quad$ Circumpacific rim

$\mathrm{Cu}, \mathrm{Au}, \mathrm{U}, \mathrm{Fe}, \mathrm{REE} \quad$ Aus, Brazil, Chile

$\mathrm{Cu}, \mathrm{Zn}(\mathrm{Pb}, \mathrm{Au}, \mathrm{Sn}) \quad \mathrm{Can}$, Iberia, Aus

Cyprus

Kuroko; Kermadec

\section{Surface ore deposits, forming at the interface between solid Earth and hydrospere + atmosphere}

Chemical sedimentation on shelf or deep ocean-floor

Evaporation of marine or continental surface water

Continental surface weathering: removal of soluble elements...

..and local redistribution

Mechanical enrichment by flowing surface water \pm wind

Banded Iron Formations ('BIF'; Ramanaidou)
Sedimentary Mn-ores (Gutzmer)
Marine ferromanganese nodules \& crusts (Hein)
Marine phosphate deposits (Piper)
Marine and non-marine salt deposits) (Warren)
$\begin{aligned} & \text { Laterite deposits: bauxite (Freyssinet) } \\ & \text { ('residual deposits') nickel laterites }\end{aligned}$

Secondary enrichment of primary ores (none?) 'supergene; sulfide and oxide deposits

Alluvial placer deposits (Robb)

Beach placers: heavy mineral sands Witwatersrand-type Conglomerates (Robb)

\begin{tabular}{|c|c|}
\hline $\begin{array}{l}\mathbf{F e} \\
\mathbf{M n} \\
\mathrm{Mn}, \mathrm{Co}, \mathrm{Ni}, \mathrm{Cu}, \mathrm{Y}, \mathrm{Te} . . \\
\mathbf{P}\end{array}$ & $\begin{array}{l}\text { Aus, Brazil, Ukraine } \\
\text { China, RSA, Aus } \\
\text { Pacific, Indian Ocean } \\
\text { USA, China, Morocco }\end{array}$ \\
\hline $\begin{array}{l}\mathrm{NaCl}, \mathrm{KCl}, \mathrm{Mg} \\
\mathrm{i}, \mathrm{B} \text {, trona }\end{array}$ & $\begin{array}{l}\text { Europe, Argentina } \\
\text { Bolivia, USA }\end{array}$ \\
\hline $\begin{array}{l}\text { Al, Ga } \\
\mathrm{Ni}\end{array}$ & $\begin{array}{l}\text { Aus, Surinam, Brazil } \\
\text { New Caledonia }\end{array}$ \\
\hline $\begin{array}{l}\text { e deposits from BIF } \\
\text { orphyry } \mathbf{C u} \text {-deposits }\end{array}$ & $\begin{array}{l}\text { Brazil, Australia, } \\
\text { SW-USA, Chile }\end{array}$ \\
\hline $\begin{array}{l}\text { Ta, Au } \\
\mathbf{Z r}, \mathrm{REE} \\
\mathbf{u}, \mathrm{U}\end{array}$ & $\begin{array}{l}\text { Malaysia, SW Asia } \\
\text { Aus, India } \\
\text { RSA (Brazil, Canada }\end{array}$ \\
\hline
\end{tabular}

Element in bold denotes that this deposit type is ist most important global source. Elements in brackets are economically less important but typically associated. Important regions indicate major world production as well as some classic study areas. Abbreviations: Aus = Australia; Can = Canada; Iberia $=$ Portugal \& Spain; RSA = Republic of South Africa 
plumes) to the convective separation of buoyant melts from generally denser solid materials (Candela, 2003). Magmatic (orthomagmatic) ore deposits owe their economic metal enrichment to a combination of selective melting from a region of previously modified ('fertile') mantle or lower crust, followed by an igneous fractionation process involving one or several melt phases (Mungall, this volume). Generally, element partitioning between melts and a 'getter' phase of distinct chemical (e.g., crystal structure, solubility in sulfide melt) and physical properties (e.g., density, viscosity) attracts selected trace elements and then separates them to form magmatic ores.

Most orthomagmatic deposits can be attributed to one of four dominant enrichment processes (Tab. 2). Very low degree of partial melting of commonly pre-conditioned upper mantle is the essential step in the enrichment of REE in carbonatites (e.g. Bayan Obo; Mountain Pass) and of P in magmatic apatite deposits related to alkaline intrusions (Kola, Palabora), in both cases followed by further magmatic differentiation involving both cystal separation and silicate - carbonate melt immiscibility. Crystal fractionation of more normal, grossly basaltic magmas and gravitational settling of early-crystallized heavy oxide minerals (chromite, V-rich magnetite) is the main mechanism for producing the world's $\mathrm{Cr}$ and $\mathrm{V}$ deposits in continental layered intrusions or at oceanic spreading centres (Cawthorn et al., 2005). Irvine (1977) suggested that nearly monomineralic layers of chromite (Fig. 2F) could form by contamination of the magma by felsic material or by mixing of more primitive magma with more evolved magma. Melt segregation, notably saturation of an immiscible sulfide melt that may accumulate by gravitational settling, is the preeminent process generating magmatic $\mathrm{Ni} \pm \mathrm{Cu}$ and PGE deposits in large layered intrusions (Sudbury, Bushveld; Naldrett, 2010) or in flood basalt and komatiitic flows and sills (Lesher et al., 1981; Barnes and Lightfoot, 2005; Li et al., 2009a; Naldrett, 2010). In all these deposits, a process of contamination of mantle-derived magmas with crustal material, commonly serving as the source of external sulfur, is key to magmatic sulfide ore formation (Arndt et al., 2005). The fourth process is extreme crystal fractionation of felsic (acid and/or alkalirich) magmas, which leads to selective enrichment of incompatible elements including Li, $\mathrm{Rb}, \mathrm{Cs}, \mathrm{F}, \mathrm{B}, \mathrm{Be}$ and $\mathrm{B}$, eventually crystallizing as distinct minerals in magmatic pegmatites (Cerny et al., 2005; see also Linnen, this volume).

Magmatic ore deposits show a distinct secular evolution, dominated by deposits formed during the Archean and Paleoproterozoic. In this early period of Earth evolution, mantle temperatures were higher and conducive to komatiite volcanism and the formation of giant layered intrusions of unique character, each giving rise to superlative mineral endowments of global significance (Naldrett, 2010; Maier and Groves, 2011). The largest among these is the Bushveld complex which, like some of the giant komatiite flows (Arndt et al., 2005), have characteristics resembling giant magma lakes and contribute our preeminent $\mathrm{Cr}$ and PGE resources. The worlds premier nickel sulfide province consists of many individual deposits at the base of the largest impact-generated melt sheet in the geological record, the Sudbury Igneous Complex. As a result of impact melting of an Archean craton, it has a unique melt composition of mixed mafic and supracrustal granite-greenstone basement (Naldrett, 2010). Related to more modern plume activity, and tentatively associated with the greatest life extinction event at the Permian - Triassic boundary (Courtillot and Olson, 2007), the Siberian trap basalts also gave rise a globally significant Ni-Cu-PGE province centered on the Norilsk mining area (Li et al., 2009a).

Although orthomagmatic ore deposits generally do not involve a low-density fluid phase as an essential agent, many magmatic deposits show evidence of some fluid activity. This includes the precipitation of gem-quality beryl, tourmaline and topaz from residual hydrothermal fluids derived from pegmatites. The origin of the world's preeminent Pt and $\mathrm{Pd}$ deposits in the Bushveld and Stillwater intrusions probably includes interaction of silicate and sulfide melts with saline hydrothermal fluids. The ongoing debate about the origin of stratiform PGE deposits related to magmatic unconformities, including the 
Merensky Reef in the Bushveld Complex, is reviewed by Mungall (this volume). Carbonatites invariably are associated with late hydrothermal alteration (fenitization) which can lead to unusual ore accumulations (e.g., $\mathrm{Cu}$ at Palabora; Groves and Vielreicher, 2001). Even the formation of chromite deposits, especially those associated with ophiolites, may require a $\mathrm{CO}_{2}$ rich fluid phase as an agent for mechanical flotation of chromite grains attached to bubbles in vertically-extensive silicate magma channelways (Cawthorn et al., 2005). We therefore turn to the preeminent role of fluid processes in hydrothermal ore formation, as the central topic of this review.

\section{Ore-forming Hydrothermal Processes}

Element enrichment by hydrothermal processes follows the principle of source - transport - deposition as illustrated in the central panel of Figure 1. The large scale of ore-forming systems requires a physical driving force for advective material transport by flowing fluids, and chemical driving forces for reactions between minerals and the transporting phase, i.e., a solubility gradient along the flow path of the fluids. Driving forces for selective element enrichment include Earth's internal energy as well external energy from the Sun. The interaction of deep and surface-driven processes contribute to the great efficiency of hydrothermal ore formation in many distinct geological environments, by establishing steep gradients in physical and chemical conditions within large-scale fluid transport systems.

\section{Physical Aspects of Hydrothermal Metal Enrichment}

\section{Energy sources driving fluid flow}

Hydrothermal fluids can be driven by the Earth's interior heat engine or by our planets external energy source, the Sun. This summary focuses on hydrothermal ore formation (Cathles, 1981; Cathles, 1997; Cox, 2010; Ingebritsen and Appold, 2011) building on the wider literature of crustal fluid flow (Fyfe et al., 1978; Cathles, 1981; Ague, 2003; Ingebritsen et al., 2006; Ingebritsen and Manning, 2010) Even though some ore deposits show textural evidence for rapid and even turbulent fluid flow, Darcy's Law is useful to discuss the key aspects of hydrothermal fluid transport (Ingebritsen et al., 2006).

Darcy's Law describing non-turbulent fluid flow through permeable rock can be expressed as:

$$
\mathrm{q}=-\left(\nabla \mathrm{p}_{\mathrm{F}}-\rho_{\mathrm{F}} \mathrm{g} \nabla \underline{\mathrm{z}}\right) \cdot \mathrm{k}_{\mathrm{R}} / \mu_{\mathrm{F}}
$$

The volumetric flow rate q (in volume units per second flowing through a cross-sectional area, the so-called Darcy velocity in $\mathrm{m} \mathrm{s}^{-1}$ ) is proportional to the fluid pressure gradient $\nabla \mathrm{p}_{\mathrm{F}}$ minus the hydrostatic pressure differential caused by the weight of the fluid, $\rho_{\mathrm{F}} \mathrm{g}$, with increasing depth, $\underline{\mathrm{z}}$ in the gravity field (Ague, 2003). The flux rate is also proportional to rock permeability $k_{R}$, but inversely related to the dynamic viscosity $\mu_{F}$ of the fluid. Several sources of energy can build up fluid pressure gradients driving fluid flow through rocks. The different energy forms lead to characteristically different rates and patterns of subsurface fluid flow, and these impact significantly on the efficiency of generating ore deposits in different geological environments (Cathles, 1997).

Solar energy evaporates water from the ocean surface and drives air convection, permitting precipitation in areas of higher elevation. This mechanical work against the Earth's gravity field creates the dominant driving force not only for surface run-off, but also for topography-driven fluid flow through rocks (Cathles and Adams, 2005). Land topography, more precisely the lateral difference in water table elevation, leads to differential pressures of hundreds of bars, which drive fluid flow through fractured basement rocks or sedimentary basins and give rise to springs and artesian wells. In terms of time-integrated fluid flow, Australia's Great Artesian Basin, the world's largest system of continental sub- 
surface water flow (Mahara et al., 2009), exemplifies the characteristics of topographydriven fluid flow through rocks. Flow is large-scale and dominantly lateral, over thousands of kilometers. It has transferred huge quantities of water in grossly the same direction over tens of millions of years, offering the potential for massive transfer of dissolved trace elements. However, flow rates through the aquifers are slow enough that the fluid is always close to thermal equilibrium with the ambient heat flow from the Earth's interior. In general, topography-driven hydrothermal systems in tectonically stable continental areas do not create significant temperature differences between fluids and rocks, even if flow is stratigraphically confined (Bethke, 1986). Minerals whose solubility is primarily controlled by temperature are therefore likely to be deposited over long distances along the transport path, rather than being concentrated in high-grade ore deposits. Topography-driven fluid systems can form economic ore deposits of metals whose solubility primarily varies with temperature-independent chemical gradients - for example, the redox gradient controlling the precipitation of $\mathrm{U}$ and $\mathrm{V}$ in sandstone-hosted ore deposits. Topography-controlled fluid pressure gradients can also modify flow paths of fluids driven by Earth's internal energy sources. For example, thermally-convecting geothermal waters on land are typically deflected to outflow points of lowest topographic elevation. Topography-driven flow of meteoric water in a volcanic edifice will interact with overpressured magmatic fluids expelled from an underlying magma chamber (Ingebritsen et al., 2010), and this hydrologic interplay probably exerts a key control on porphyry-related and epithermal ore deposits (Driesner and Geiger, 2007).

Thermal convection driven by Earth's interior heat is the dominant driving force for fluid flow through the oceanic crust, because the overlying ocean surface imposes a level of constant potential in the gravity field. Convection is driven by lateral gradients of fluid density, which can be caused by fluid composition (e.g. salinity: thermohaline convection along a salt diapir; fingering of an overlying saline aquifer into an underlying freshwater aquifer). More commonly, lateral fluid density gradients are caused by temperature differences, leading to thermal convection. We distinguish forced thermal convection due to an imposed horizontal temperature gradient (e.g., along the steep wall of a hot intrusion into cooler water-saturated rocks; Cathles, 1981) from spontaneous thermal convection caused by a sufficiently large vertical temperature gradient, including seawater convection beneath mid-oceanic ridges (Fisher, 2005).

Thermal convection has two inherent 'advantages' for efficient hydrothermal ore formation. First, fluid flow can self-organize into relatively stable patterns with locally steep thermal gradients (notably at the base and at the top of convection cells). This leads to large integrated fluid fluxes favoring massive solute transfer, combined with a sustained chemical driving force for mineral dissolution and precipitation. Second, it provides a mechanism of self-focusing of fluids from large areas of extensive contact with rock (amenable to leaching of trace metals) to areas of high fluid flux (favoring concentrated mineral deposition, e.g., in black smoker fields) - even without any variations in rock permeability (e.g., Coumou et al., 2008). The main limitation for convective fluid transport is its restriction to regions of the crust that are sufficiently permeable to sustain hydrostatic fluid pressure gradients. Thus, large-scale convection is generally restricted to the permeable upper part of the crust where pore fluids effectively communicate with the water table near the land surface or with the open ocean.

Essentially hydrostatic conditions extend from the surface to a characteristic depth, depending on geological and tectonic environment. The transition from hydrostatic to overpressured conditions varies from a few kilometers in regions of rapid sedimentation of impermeable clays in the Gulf of Mexico (Reilly and Flemings, 2010) to at least $~ 10 \mathrm{~km}$ in most areas of stable crystalline crust (Huenges et al., 1997; Townend and Zoback, 2000). For average continental crust, Ingebritsen and Manning (2010) suggested from geothermal 
and metamorphic data on fluid fluxes that average rock permeability $\left(\mathrm{k}_{\mathrm{R}}, \mathrm{m}^{2}\right)$ decreases with depth $(\mathrm{z}, \mathrm{km})$ according to the relation:

$$
\log \mathrm{k}_{\mathrm{R}}=-14-3.2 \log \underline{\mathrm{z}}
$$

$\log \mathrm{k}_{\mathrm{R}} \sim 10^{-17} \mathrm{~m}^{2}$ at $10-15 \mathrm{~km}$ depth in the crust is an effective lower limit for the permeability sustaining fluid flow and hydraulic connectivity to the Earth's surface, and this depth range corresponds to the brittle - ductile transition zone of quartz + feldspar-rich rocks. However, transient periods following active fracturing (e.g., in the region of aftershocks following major earthquakes, or artificially induced by hydraulic fracturing of geothermal reservoirs) raise this baseline permeability of the continental crust by 2-3 orders of magnitude (Townend and Zoback, 2000; Evans et al., 2005; Rojstaczer et al., 2008) over periods of $\sim 1-10^{3} \mathrm{y}$ (Ingebritsen and Manning, 2010). This is likely to allow episodes of significant thermal convection throughout the seismogenic part of the continental crust and may be a key to basement fluid injection into basin-hosted ore systems (Deming, 1992; Koziy et al., 2009; Boiron et al., 2010).

Under the term of rock deformation we subsume a range of processes driving fluid flow at pressures that transiently exceed hydrostatic. These may be active from the upper crust down to mantle depths. In sedimentary basins, sediment compaction determines the transition from the region of hydrostatic conditions near the surface to over-pressured fluids deeper down. A steep gradient of increasing fluid pressure is typically located at an impermeable layer separating the two hydrologic regimes. Basin dewatering by rock compaction has been invoked as a possible driver for the formation of hydrothermal ore deposits along basin margins, e.g., the Mississippi Valley-type Pb-Zn deposits (Fig. 2C). However, these deposits show indications of rapid pulses of hot brine advection (e.g. (Rowan et al., 2002), and such thermal anomalies are difficult to reconcile with the slow process of basin dewatering, driven by gradual infill of overlying strata (Cathles and Adams, 2005). More active forms of rock deformation may be essential for driving effective flow of ore fluids through sedimentary basins and underlying basement rocks, such as orogenrelated tilting or fault-related uplift of basin margins, which can build up a transient topographic pressure head (Bethke, 1986; Leach et al., 2005b).

In the crystalline crust, seismic fracturing can lead to almost instantaneous breaching of seals between an overpressured regime at depth and a hydrostatic pressure regime above (Sibson, 1992). The resulting steep and transient gradients in pressure and temperature, and the possible confluence of fluids from different chemical environments, favor the formation of ore deposits. On the other hand, the quantity of available fluid is limited by the accessible pore volume in the overpressured rock reservoir prior to the fracturing event. Therefore, the formation of gold-bearing quartz veins from metamorphic fluids by this mechanism typically requires numerous cycles of fluid accumulation, cracking, flow and resealing of veins by precipitating minerals (Cox, 2005).

Magma ascent in the crust also occurs by active crack formation (diking), driven by lithostatic overpressure of lower-density magma under the weight of denser rocks overlying the melt generation zone. When a hydrous magma reaches the upper crust, it crystallizes to an igneous rock and thereby expells excess volatiles as hydrous fluid. The resulting net volume increase $\left(\mathrm{V}_{\text {Fluid }}+\mathrm{V}_{\text {IgneousRock }}>\mathrm{V}_{\text {HydrousMelt; }}\right.$ Burnham and Ohmoto, 1980) contributes an additional driving force $(\mathrm{p} \bullet \Delta \mathrm{V})$ for hydraulic fracturing and rapid fluid flow. Thus, a large crystallizing intrusion can rapidly drain its fluid through a cupola in its roof, thereby forming a porphyry-copper deposit (Burnham and Ohmoto, 1980; Dilles and Einaudi, 1992).

\section{Fluid focusing and 'structural control'}

Focused fluid flow may result from convective self-organization, even in a rock of homogeneous permeability. However nearly all ore-forming hydrothermal systems include 
evidence of additional focusing of fluids by geological structures of enhanced permeability, e.g., sedimentary aquifers or zones of fracturing. Known as 'structural control' by the exploration geologist, tectonic structures localizing increased fracture permeability are a key factor determining the location of most major ore deposits.

At the lithospheric to crustal scale, irregularities in a compressive subduction suture can lead to localized extension. Commonly, preexisting crustal structures act as a focus for magma ascent along a plate boundary and determine the sites of major magmatic centres (e.g., four giant magmatic-hydrothermal gold and/or copper deposits in Papua New Guinea and Irian Jaya: Ok Tedi, Frieda River, Porgera and Grasberg). Hill et al. (2002) proposed that, during orogenesis and crustal thickening in an overall compressive setting, strike-slip motion occurred along fracture zones roughly parallel to the convergence vector. Localized zones of dilation opened where these fracture zones intersected major orthogonal faults and other structural discontinuities, facilitating igneous intrusion and subsequent mineralization.

At the scale of individual deposits and ore bodies, faults and shear zones collect fluids from large source regions with dispersed fluid transport. In regional metamorphic terrains, orogenic gold vein deposits are localized by a continuum of lower-crustal ductile shear zones to upper-crustal brittle faults and large veins (Ridley, 1993; Ridley et al., 1996; Goldfarb et al., 2005). In sedimentary basins, stratabound (Fig. 2C) and even synsedimentary-exhalative deposits (Fig. 2B) are localized by faults acting as focusing channelways for hydrothermal fluids ascending from subjacent basin fill or from underlying basement (Leach et al., 2005b).

\section{Timescales of fluid flow and heat transfer}

Just as ore formation encompasses an interaction of processes at different spatial scales, it also involves a range of characteristic time scales. These are governed primarily by rates of advective and diffusive heat transfer. Geodynamic processes creating environments for ore formation have characteristic lifetimes of tens of millions of years, including basin formation, orogenic accretion and regional metamorphism, or the development of lowercrustal hydrous magma reservoirs in response to specific plate interactions (e.g., England and Thompson, 1984; Rohrlach and Loucks, 2005). Large upper-crustal magma chambers crystallize more rapidly, typically within less than a million years, even if cooling occurs by conductive heat loss alone (Cathles, 1981).

Fluid-flow processes leading to formation of mineral deposits are typically fast compared with basin evolution, orogenesis, and even the life time of a batholith-sized upper-crustal magma chamber (Cathles and Adams, 2005). Diagnostic evidence comes from observations that ore deposits are commonly transient thermal anomalies compared to the ambient geothermal gradient, even in areas without any magmatic heat input. For example, fluid inclusions in some sediment-hosted ore deposits record higher temperatures during pulses of hydrothermal $\mathrm{Pb}-\mathrm{Zn}$ deposition, compared with ambient rock temperatures recorded by the maturation level of organic matter (e.g., Henry et al., 1992; Rowan et al., 2002). Such observations imply that advection of heat by ore-forming fluid flow is fast relative to the conductive dissipation of heat to the surrounding rocks, which places rigorous constraints on the duration of ore formation in sedimentary basins (1000-10'000 years; Cathles and Adams, 2005). Temperature gradients based on fluid inclusion data and physical modeling of magmatic-hydrothermal ore systems indicate similar lifetimes (Hayba and Ingebritsen, 1997; Kostova et al., 2004; Driesner and Geiger, 2007), consistent with evidence from active geothermal systems (Simmons and Brown, 2007). At the scale of alteration zones around veins, chemical diffusion through the pore fluid may be even faster than heat diffusion. The width of such haloes has been used by Cathles and Shannon (2007) to argue that formation of veins, and possibly major magmatic-hydrothermal orebodies, may require as little as 10100 years (see also Ridley and Mengler, 2000, for veins shown in Figure 2D). 
Such physical considerations lead to the conclusion that the duration of ore-forming processes, i.e., the times when mineralization actively proceeds at the scale of an orebody, is generally small compared with the precision of radiometric age dating based on long-lived radioactive isotopes, for all but the youngest or currently active systems (cf. Stein et al., this volume). U-Th disequilibrium dating of submarine magmatic-hydrothermal mineralization confirms a timescale of years to hundreds of years (De Ronde et al., 2005), consistent with the transient dynamics of black smoker output recorded by direct fluid probing over a few years (Von Damm, 2005).

\section{Chemical Driving Forces for Hydrothermal Metal Enrichment}

Physical transport of heat and matter invariably leads to chemical separation by fractionation of elements between solid minerals and the transporting melt or fluid. Solubility gradients along the fluid transport path are the chemical driving force for metal enrichment. Metal solubility in hydrothermal systems is typically low, but highly variable and element-specific (Brimhall and Crerar, 1987; Giggenbach, 1997; Reed, 1997; Seward and Barnes, 1997; Seward and Williams-Jones, this volume). Solubility is controlled by pressure, temperature, and a few chemical master variables imposed by the major-element compositions of rocks and fluids, including ligand concentrations in the fluid, and mineral buffers in crustal rocks controlling $\mathrm{pH}$ and redox potential.

\section{Rock buffering and fluid-chemical master variables}

Any ore-forming hydrothermal transport system requires a large volume of rock (or magma) from which initially dispersed ore-forming components are released. This source region of the system requires dispersed fluid flow, enabling extensive contact and chemical reaction between the fluid and the source material. Such conditions represent the normal state of crustal fluids, in which the instantaneous ratio of fluid to rock is small, due to the generally small porosity of rocks. To a first approximation, we can consider the source region approaching a state in which fluid is chemically equilibrated with an infinite excess of the rock through which it flows. Equilibration is favored by the fact that dispersed fluid flow means slow local flow rates along grain boundaries and in many small fractures. In a state of rock-dominated equilibration, the mineralogy of the rock is "buffering" the chemical master variables, imposing them on the fluid. These master variables in turn determine the solubility of minor elements.

Solution $\mathrm{pH}$ and salinity are two related master variables affecting metal solubility. In fluids equilibrated with common crustal rocks, $\mathrm{pH}$ is buffered by carbonate equilibria, or by hydrolysis reactions among alkali feldspars and sheet silicates such as muscovite. The Alconservative reaction ( $\mathrm{Al}$ being the least soluble element):

$$
\begin{aligned}
& 1.5 \mathrm{KAlSi}_{3} \mathrm{O}_{8}+\mathrm{H}^{+}=0.5 \mathrm{KAl}_{3} \mathrm{Si}_{3} \mathrm{O}_{10}(\mathrm{OH})_{2}+3 \mathrm{SiO}_{2}+\mathrm{K}^{+} \\
& \text {ksp }+\mathrm{H}^{+}=\text {mus }+\mathrm{qtz}+\mathrm{K}^{+} \\
& \longrightarrow \log \mathrm{K}_{\mathrm{eq}}=\mathrm{pH}+\log \mathrm{a}_{\mathrm{K}^{+}}
\end{aligned}
$$

shows that, at given pressure and temperature, the $\mathrm{pH}$ of a fluid in equilibrium with a micabearing granite assemblage will be inversely related to the $\mathrm{K}^{+}$activity in the fluid. The potassium ion actvity, in turn, is approximately proportional to the $\mathrm{Na}^{+}$activity in the fluid, by equilibration with sodic (albite) and potassic feldspar (ksp) components in the rock:

$$
\begin{aligned}
\mathrm{NaAlSi}_{3} \mathrm{O}_{8}+\mathrm{K}^{+}= & \mathrm{KAlSi}_{3} \mathrm{O}_{8}+\mathrm{Na}^{+} \\
\mathrm{alb}+\mathrm{K}^{+}=\mathrm{ksp}+ & \mathrm{Na}^{+} \\
\longrightarrow & \log \mathrm{K}_{\mathrm{eq}}=\log \mathrm{a}_{\mathrm{Na}^{+}}-\log \mathrm{a}_{\mathrm{K}^{+}} \\
& =\log \left(\mathrm{a}_{\mathrm{Na}^{+}} / \mathrm{a}_{\mathrm{K}^{+}}\right)
\end{aligned}
$$


To satisfy charge balance, the total alkali concentration must be balanced by anions, dominantly $\mathrm{Cl}^{-}$in most hydrothermal fluids. This leads to the important conclusion that, the higher the chloride concentration of a granite- (or arkose) -buffered fluid, the higher will be its $\mathrm{K}^{+}$and therefore its $\mathrm{H}^{+}$activity (Montoya and Hemley, 1975; Yardley, 2005). In simple terms: salty fluids are acid fluids.

Analogous reactions buffer the acidity of fluids in clay-rich but feldspar free sediments, at distinctly lower $\mathrm{pH}$, by equilibria between muscovite (or illite) and kaolinite (kao):

$$
\begin{aligned}
& \mathrm{KAl}_{3} \mathrm{Si}_{3} \mathrm{O}_{10}(\mathrm{OH})_{2}+1.5 \mathrm{H}_{2} \mathrm{O}+\mathrm{H}^{+} \quad=1.5 \mathrm{Al}_{2} \mathrm{Si}_{2} \mathrm{O}_{5}(\mathrm{OH})_{4}+\mathrm{K}^{+} \\
& \text {mus } \quad+\mathrm{H}^{+} \quad=\quad \text { kao } \quad+\mathrm{K}^{+} \quad \log \mathrm{K}_{\mathrm{eq}} \sim \mathrm{pH}+\log \mathrm{aK}^{+}
\end{aligned}
$$

Equilibria (3) to (5) constrain the $\mathrm{pH}$ of common crustal fluids from near-neutral to slightly acid conditions (whereby neutral $\mathrm{pH}$ shifts from 7 at room temperature to 5.7 at $300^{\circ} \mathrm{C}$; Seward and Williams-Jones). With increasing temperature, the total acid concentration $\left(\mathrm{H}^{+}\right.$ $+\mathrm{HCl})$ as well as the potassium content of rock-buffered salty fluids increases, also as a result of increased ion association, and both are approximately proportional to total chlorinity (Montoya and Hemley, 1975).

Redox potential is the third master variable, and is partly related to sulfur chemistry of fluids in equilibrium with common crustal rocks. Redox potential in rock-dominated hydrothermal systems is imposed by equilibria among Fe(II) and Fe(III) oxides, sulfides and silicates (e.g. hematite, magnetite, pyrrhotite, pyrite, chlorite, epidote, etc.). The predominance of oxides and silicates in rocks is the reason why oxygen fugacity $\left(\log f_{02}\right)$ is commonly used as a thermodynamic measure of redox potential, even though free oxygen is absent in the reducing interior of the Earth. Hydrogen fugacity $\left(\log \mathrm{f}_{\mathrm{H} 2}\right)$ or activity $\left(\log \mathrm{a}_{\mathrm{H} 2, \mathrm{aq}}\right)$ are alternative redox scales for water + rock systems, coupled to $\mathrm{f}_{02}$ by the equilibrium $\mathrm{H}_{2} \mathrm{O}$ $=\mathrm{H}_{2}+0.5 \mathrm{O}_{2}$; hydrogen indeed occurs in measurable concentrations in deep crustal fluids (Giggenbach, 1992, 1997).

Redox potential spans a great range even in common rock-dominated fluids. In systems containing reduced carbon (usually of biogenic origin: kerogen, graphite, liquid hydrocarbon, methane), fluids are too reduced to contain appreciable sulfate under equilibrium conditions, and coexisting $\mathrm{Fe}$ minerals are essentially ferrous. Because the $\mathrm{Fe}^{2+} / \mathrm{Fe}^{3+}$ and $\mathrm{S}^{2-} / \mathrm{S}^{+6}$ pairs have comparable redox potentials, hydrothermal fluids in equilibrium with assemblages containing both Fe(III) (epidote, hematite, magnetite) and $\mathrm{Fe}(\mathrm{II})$ minerals (Fe-Mg silicates like chlorite or amphibole) typically contain dissolved sulfur in sulfide as well as sulfate form. This is reflected in Fig. 4 by the heavy green lines delimiting the hematite stability against the fields of pyrite and magnetite, straddling the predominance boundaries of $\mathrm{HSO}_{4}{ }^{-}$against $\mathrm{H}_{2} \mathrm{~S}$ and $\mathrm{HS}^{-}$. The vicinity of the $\mathrm{Fe}^{2+} / \mathrm{Fe}^{3+}$ buffer in rocks and the $\mathrm{S}^{2-} / \mathrm{S}^{+6}$ redox couple in hydrothermal fluids means that the concentration ratios among sulfide, sulfate and dissolved $\mathrm{Fe}^{2+}$ species commonly dominates the redox balance within crustal fluids (Giggenbach, 1997). They are expected to exert a dominant control on other redox-sensitive fluid equilibria involving trace-elements of lower concentration (Drummond and Ohmoto, 1985). Very oxidizing conditions high in the sulfate-only (fluid) and ferric minerals-only (rock) field originate from direct or indirect influence of the oxygen-rich atmosphere. For example, oxygenated water flowing into aquifers advects $\mathrm{U}$ and $\mathrm{V}$ towards zones of reduction in the subsurface, forming sandstonehosted ore deposits. 


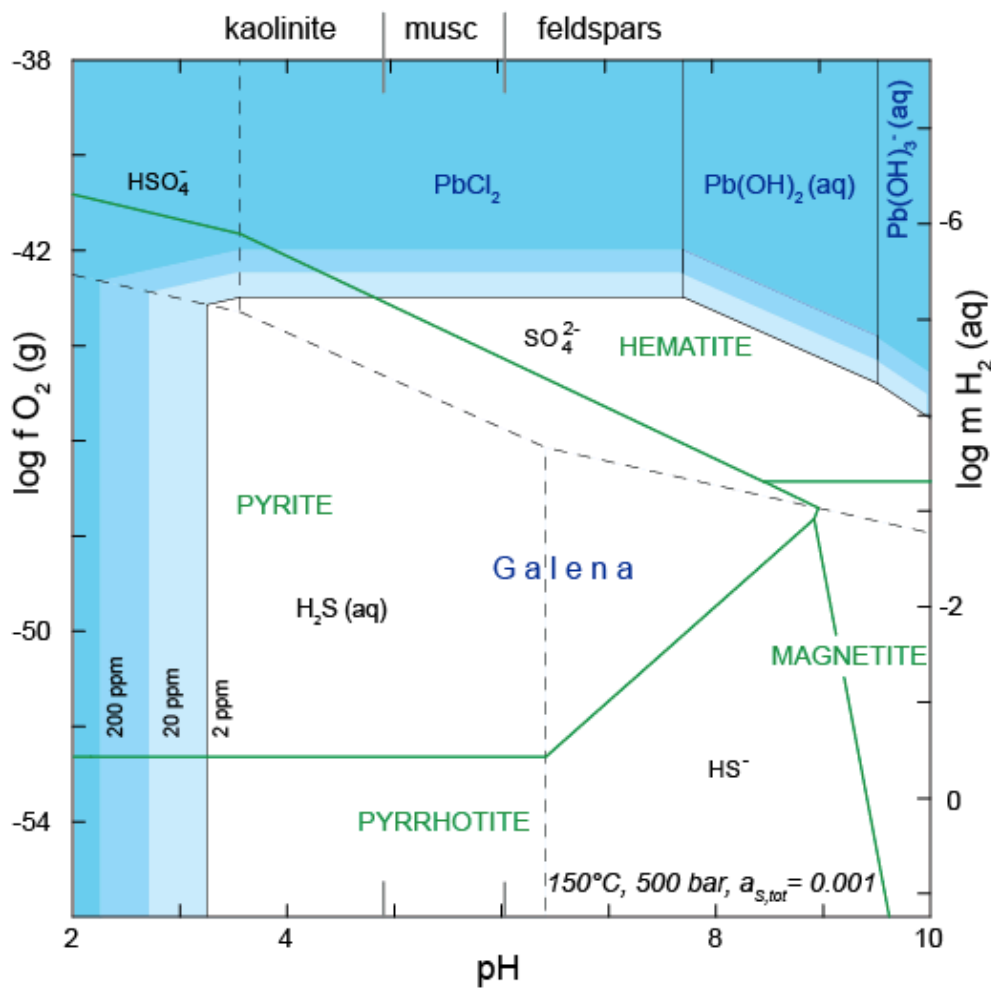

Fig. 4: $p H$-redox diagram of the $\mathrm{H}_{2} \mathrm{O}-\mathrm{Fe}-\mathrm{S}-\mathrm{O}-\mathrm{H}-\left(-\mathrm{Al}_{2} \mathrm{O}_{3}-\mathrm{SiO}_{2}-\mathrm{K}-\right.$ $\mathrm{Na}-\mathrm{Pb}-\mathrm{Cl}-\mathrm{C}$ ) system at $150^{\circ} \mathrm{C}$, showing the stability fields of common iron oxides and sulfides in crustal rocks (green lines), assuming equilibrium with an aqueous fluid containing a fixed total concentration of sulfur equivalent to an activity of $10^{-3}$ mol $/ \mathrm{kg}$ of variable $S$ species, $\mathrm{H}_{2} \mathrm{~S}, \mathrm{HS}^{-}, \mathrm{HSO}_{4}^{-}$or $\mathrm{SO}_{4}^{2-}$. The predominance of $S$ species varies as a function of $p H$ and $f_{02}$, as delimited by the dashed iso-composition lines. The main pH buffers in common crustal rocks among feldspars, muscovite and clay minerals (eq. 3, 4 and 5) are indicated by vertical grey lines along the top axis of the diagram.

The blue shadings show the solubility of galena

approximating 2, 20 and 200 ppm in a saline fluid with $a_{C T^{-}} \sim 1$, depending on $\mathrm{pH}$ or redox potential according to the changing sulfur species predominating in the fluid. Ignoring activity coefficients, 200 ppm $\mathrm{Pb}$ is approximately equivalent to the assumed molar sulfur concentration, as required to precipitate the solubility-limiting mineral, $\mathrm{PbS}$, whereas lower $\mathrm{Pb}$ concentrations imply sulfur excess in the solution. Calculated from thermodynamic data by Seward (1984) and compilations by Holland and Powell (1998), Sverjensky et al. (1997) and Dolejs and Wagner (2008).

\section{Sulfide solubility and base-metal content of crustal fluids}

Seward and Williams-Jones (this volume) review the thermodynamics of metal complexation and the solubility of ore minerals, based on extensive experimental research. Such data are the chemical foundation for the following section, which emphasizes the effect of the hydrothermal master variables (above) on base metal ( $\mathrm{Cu}, \mathrm{Pb}, \mathrm{Zn}$, also $\mathrm{Mn}$, Co and $\mathrm{Fe}$ ) solubility and the observed ranges of metal concentrations in upper-crustal fluid - rock systems.

pH and salinity have a mutually enhancing effect on solubility of many metals. Where sulfide, oxide or silicate minerals limit ore metal solubility, increasing $\mathrm{H}^{+}$activity will promote dissolution, e.g.:

$$
\begin{aligned}
& \mathrm{MnO}+2 \mathrm{H}+\longrightarrow \mathrm{Mn}^{2+}+\mathrm{H}_{2} \mathrm{O} \\
& \mathrm{PbS}+2 \mathrm{H}+\longrightarrow \mathrm{Pb}^{2+}+\mathrm{H}_{2} \mathrm{~S}
\end{aligned}
$$

Most cations form chloride complexes in aqueous solutions, which are increasingly stable with increasing temperature. Aqueous complex formation enhances metal solubility by orders of magnitude, as illustrated by the equilibria:

$$
\begin{aligned}
& \mathrm{PbS}+2 \mathrm{H}+\quad \rightarrow \mathrm{Pb}^{2+}+\mathrm{H}_{2} \mathrm{~S} \quad \log \mathrm{K}_{\mathrm{eq}}\left(150^{\circ} \mathrm{C}, 500 \text { bar }\right)=-4.48 \\
& \mathrm{PbS}+2 \mathrm{H}^{+}+2 \mathrm{Cl}^{-} \longrightarrow \mathrm{PbCl}_{2}^{-}+\mathrm{H}_{2} \mathrm{~S} \quad \log \mathrm{K}_{\mathrm{eq}}\left(150^{\circ} \mathrm{C}, 500 \text { bar }\right)=-1.43
\end{aligned}
$$

defining the vertical isopleths of galena solubility in the $\mathrm{H}_{2} \mathrm{~S}$ predominance field of Fig. 4. Comparing the two equilibrium constants indicates an approximately 1000 -fold increase in lead solubility in a galena-saturated fluid with a chloride activity of 1 (approximating seawater salinity) compared to pure water, at given sulfide concentration and $\mathrm{pH}$. The effect of complexing on solubility is compounded by the effect that rock-buffered salty fluids are 
more acid than low-salinity fluids, as increased $\mathrm{H}^{+}$activity additionally promotes sulfide (and oxide and silicate) dissolution (reactions 3 to 5).

Redox potential can affect metal solubility for two reasons. First, it controls the solubility of metals with a difference in valence state between their solid and dissolved forms, as exemplified by $\mathrm{U}$ and $\mathrm{V}$ in sandstone-hosted deposits, but also $\mathrm{Fe}, \mathrm{Cu}, \mathrm{As}, \mathrm{Mo}, \mathrm{Sn}, \mathrm{Au}, \mathrm{Pd}, \mathrm{Pt}$, $\mathrm{Au}$ and other ore metals. Second, redox potential controls the proportions of oxidized sulfate and reduced sulfide species in solution, which impacts on the solubility of all transition metals forming sparingly soluble metal sulfides including $\mathrm{Fe}, \mathrm{Co}, \mathrm{Ni}, \mathrm{Cu}, \mathrm{Zn}, \mathrm{Pb}$ and many others. Thus, the solubility of galena in the $\mathrm{HSO}_{4}{ }^{-}$and $\mathrm{SO}_{4}{ }^{2-}$ predominance fields of Fig. 4 are defined, respectively, by the oxidation reactions:

$\mathrm{PbS}+\mathrm{H}^{+}+3 \mathrm{Cl}^{-}+\mathrm{O}_{2} \longrightarrow \mathrm{PbCl}_{3}^{-}+\mathrm{HSO}_{4^{-}}$
$\mathrm{PbS}++3 \mathrm{Cl}^{-}+\mathrm{O}_{2} \longrightarrow \mathrm{PbCl}_{3}+\mathrm{SO}_{4}{ }^{2-}$

even though $\mathrm{Pb}$ does not change its nominally divalent oxidation state. As a result, base metals are highly soluble under oxidizing conditions, and can be co-transported with sulfur if it is present in sulfate form.

Aqueous sulfur chemistry is of particular importance to hydrothermal ore formation, not only as a solubility-limiting component for sulfide minerals, but also by acting as an acid/base buffer, as the dominant redox couple among species in many natural hydrothermal solutions, and as a complexing ligand for some metals - as illustrated for gold transport in the following section.

Sulfur isotopes most strongly fractionate between sulfate and sulfide species, both in solution and among solid minerals (Shanks and Ridley, this volume). Variations in sulfur isotopic composition therefore provide information about

Fig. 5: Lead concentration in selected crustal fluids and rockbuffered solubilities of galena (PbS) as a function of temperature, plotted on a $1 / T$ scale. Experimental curves from Hemley et al. (1992) for fluids with $1 \mathrm{~m}$ total $\mathrm{Cl}$, buffered by excess feldspars + muscovite + quartz + pyrite + pyrrhotite + magnetite + galena (red line; dashed extension by thermodynamic calculation from data cited in Fig. 4). Small black symbols show analysed $\mathrm{Pb}$ concentrations in natural magmatic-hydrothermal,

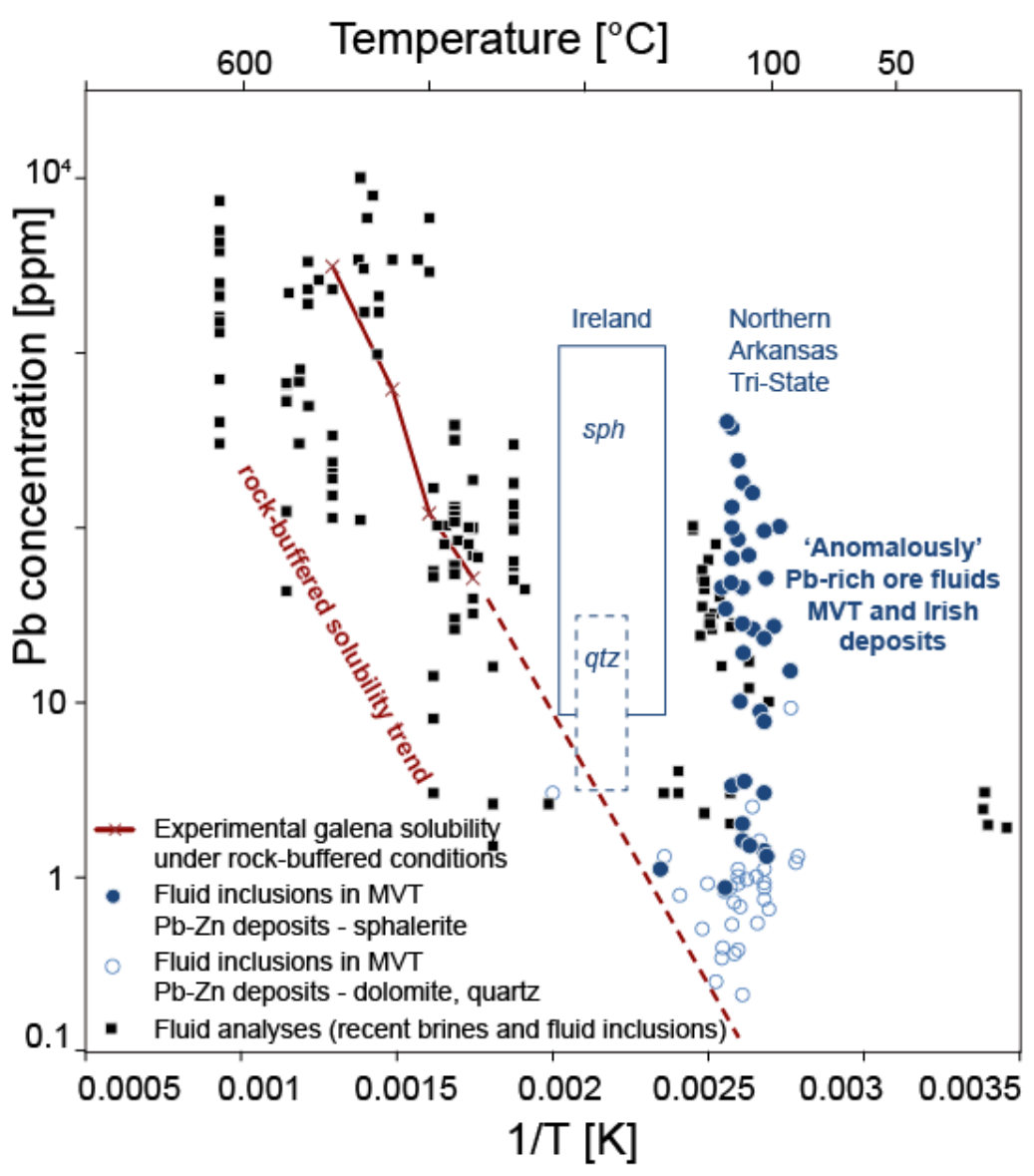
geothermal and basin brines with inferred tempertures of crustal rock equilibration, compiled by Yardley (2005). Blue symbols and boxes show fluid inclusion analyses from carbonate-hosted Pb-Zn ore deposits by Stoffell et al. (2008) and Wilkinson et al. (2009), differentiating ore-stage fluids in sphalerite (solid box, full cicles) and intervening stages of gangue mineral precipitation (quartz, carbonates; dashed box and open circles). 
redox reactions in hydrothermal systems, to the point that great variability of $\delta^{34} S$ among sulfides can be taken as first-order evidence for significant involvement of sulfate in an oreforming process (Ohmoto, 1986).

Temperature is the main physical variable controlling mineral solubility in aqueous fluids. While carbonate and sulfate mineral solubilities decrease with increasing temperature (Rimstidt, 1997), the solubilities of base metal sulfides and metal oxides rapidly increase with rising temperature. The solubility of galena, sphalerite and chalcopyrite, and also of cassiterite, Fe-oxides and Fe-sulfides in saline crustal fluids buffered by common rockforming minerals, show an approximately linear relationship with $1 / \mathrm{T}$, as determined experimentally (Hemley et al., 1992) and found empirically by compilation of natural fluid analyses. This is exemplified by Figure 5, showing that $\mathrm{Pb}$ solubility in crustal fluids varies over at least 5 orders of magnitude, with a generally steep increase with rising $T$, which becomes even tighter if metal concentrations are normalised to chloride content of the fluids (Yardley, 2005). Similar relations are found for $\mathrm{Cu}, \mathrm{Zn}, \mathrm{Mn}$ and $\mathrm{Fe}$, showing that temperature and salinity are the most decisive enhancers of metal solubility. To a first approximation, therefore, any hot and salty crustal fluid can become an effective ore fluid (Yardley, 2005). However, the scatter around the temperature trend (Fig. 5) also emphasizes that base metal concentrations vary up to 3 orders of magnitude at any given temperature. This variation may be decisive for hydrothermal ore formation, especially at low temperature. It is probably a result of variations in the other master variables, notably redox potential and sulfur concentration. Note that many low-temperature brines have $\mathrm{Pb}$ concentrations well above the rock-buffered solubility line (red). These include 'anomalously' $\mathrm{Pb}$-rich solutions in fluid inclusions hosted by sphalerite in Mississippi Valley-type (MVT) and Irish Pb-Zn deposits, which contrast with relatively metal-poor fluids in associated gangue minerals of the same deposits (Stoffell et al., 2008; Wilkinson et al., 2009). Similar to some recent basin brines (Kharaka et al., 1987), these ore-forming fluids must be sulfide-deficient, either due to sulfate predominance under unusually oxidizing conditions at their source (Fig. 4) or as a result of a distinct chemical evolution path experienced during cooling from higher temperatures. Initially hotter fluids cooling in equilibrium with pyrite and Fe-silicates may become sulfide deficient and support correspondingly higher concentrations of $\mathrm{Pb}$ and $\mathrm{Zn}$ down to low temperatures. Such sulfurdeficient brines are highly efficient metal carriers, but require an external sulfide source for ore deposition, e.g., preexisting sedimentary pyrite or $\mathrm{H}_{2} \mathrm{~S}$ from biogenic sulfate reduction (e.g., Plumlee et al., 1994; Fallick et al., 2001).

Pressure has a subordinate effect on equilibria involving relatively incompressible aqueous liquids at temperatures well below the critical point of water $\left(374^{\circ} \mathrm{C}\right)$. Hopwever, it becomes a controlling variable in hot vapor-like fluids dominating in magmatichydrothermal systems, as discussed in the section on magmatic-hydrothermal processes (below) and explained in the chapter of Seward and Williams-Jones (this volume).

\section{Hydrothermal re-distribution of gold}

Lead, zinc, copper, iron and many other metals form stable sulfide and oxide minerals that limit their solubility in crustal fluids, and complexation with $\mathrm{Cl}^{-}$and possibly $\mathrm{Br}^{-}$in saline fluids is essential to allow adequate transport concentrations for hydrothermal ore formation. Other scarce metals and metalloids are dominantly transported as mixed-ligand or hydroxy species (e.g., $\mathrm{H}_{3} \mathrm{AsO}_{3} ; \mathrm{H}_{3} \mathrm{SbO}_{3}, \mathrm{H}_{2} \mathrm{MoO}_{4}, \mathrm{H}_{2} \mathrm{WO}_{4}$ and their deprotonated anions) or in the form of stable complexes with sulfur ligands (e.g., $\mathrm{Au}(\mathrm{HS})_{2^{-}}, \mathrm{AuHS}^{0}$ and possibly more complex species such as $\mathrm{AuSO}_{3} \mathrm{HS}^{0}$ ). Oxidizing conditions enhance the solubility of these metals and metalloids, e.g., as aqueous $\mathrm{Au}(+\mathrm{I})$, Mo (+VI) or As(+III) species, relative to native $\mathrm{Au}(0)$ or sulfide minerals such as $\mathrm{Mo}(+\mathrm{IV}) \mathrm{S}_{2}$ and FeAsS. Gold, wolframite and Mo, As and $\mathrm{Sb}$ sulfide minerals are not known to be ubiquitous accessories in common rocks, so 
that the concentration of the respective elements in the fluid may not be constrained by simple saturation equilibria.

Gold serves as example of a metal that may commonly be leached from the source region of hydrothermal systems where its thermodynamic activity (i.e., saturation level) is less than one. Gold has a crustal abundance of 3ppb (Taylor and Mclennan, 1995). In common rocks it can be hosted either as metallic microparticles or as a trace component in sulfide solid solutions such as pyrite or bornite (Simon et al., 2000; Candela, 2003). In natural silicate melts, gold is dissolved at activity levels that are several orders below 1. Experimental measurements indicate that the solubility of gold in rhyolitic melts is between 0.3 and $1 \mathrm{ppm}$ at the temperature, pressure and chemical conditions that occur in fluidsaturated upper-crustal magmatic systems (Frank et al., 2002). This is 100-1000 times higher than its concentration in glassy melt inclusions of common magmatic rocks $(\sim 1 \mathrm{ppb}$; Connors et al., 1993). The comparison of experimental and microanalytical data implies that gold activity in natural magmas is on the order of $10^{-2}-10^{-3}$. The gold concentrations of magmatic and probably other high-temperature crustal fluids is therefore not limited by metal saturation, but rather by the degree of gold enrichment in silicate melt and its partition coefficient between fluid and the melt or a solid-solution phase. Also in metamorphic fluid systems, where prograde devolatilization of metasediments or hydrated mafic rocks is believed to generate ore fluids for metamorphogenic gold - quartz lode mineralization (Goldfarb et al., 2005), gold solubility in high-grade metamorphic source regions may be so high that the gold concentration in the fluid is limited by gold availability, rather than by saturation with native gold.

At near-magmatic temperatures, gold is transported by chloride complexes in brines (Gammons and Williams-Jones, 1997) or by polyatomic alkali-chloride - gold-sulfide species in lower-salinity vapor (e.g., H2S-Au-SH.NaCl; Zajacz et al., 2010). With falling temperature, chloride species become unimportant except at extremely acid and oxidising conditions, and give way to stable bisulfide complexes, $\mathrm{AuHS}^{0}$ and $\mathrm{Au}(\mathrm{HS})_{2}{ }^{-}$(Stefánsson and Seward, 2004). The latter species allows up to tens of ppm of gold solubility in sulfur-rich fluids at near-neutral and moderately oxidizing conditions (Fig. 6). In the $\mathrm{H}_{2} \mathrm{~S}$ predominance field of aqueous sulfur, gold solubility is defined by the equilibrium

$$
\mathrm{Au}+2 \mathrm{H}_{2} \mathrm{~S}+0.5 \mathrm{O}_{2}=\mathrm{Au}(\mathrm{HS})_{2^{-}}+\mathrm{H}^{+}+0.5 \mathrm{H}_{2} \mathrm{O}
$$

This reaction shows that the solubility of gold increases by oxidation of $\mathrm{Au}(0)$ to $\mathrm{Au}(+\mathrm{I})$, and is maximized by mildly alkaline $\mathrm{pH}$ conditions, opposite to the $\mathrm{pH}$ dependence of most oxide and sulfide solubility reactions (eq. 6 -8). For a given total sulfur concentration in the fluid, gold solubility peaks at conditions where $\mathrm{H}_{2} \mathrm{~S}, \mathrm{HS}^{-}$and $\mathrm{HSO}_{4}$ - have sub-equal concentrations (Fig. 6). Gold solubility rapidly decreases again at more oxidizing conditions, where sulfide gives way to sulfate species, which are poor complexing ligands for gold.

Gold deposition, like gold sequestering from source regions, can occur either by saturation with the pure metal $( \pm$ some dilution by $\mathrm{Ag}$ ) or by extraction under conditions where gold activity is significantly less than one. Three mechanisms can shift equilibrium (9) towards the left, and these characterize three different environ-ments of gold ore deposition. The first involves removal of $\mathrm{H}_{2} \mathrm{~S}$ and consequent de-complexation of gold. This can occur by reaction with Fe-rich wall rocks to form pyrite (a major mechanism in metamorphogenic gold quartz lodes; Phillips and Groves, 1983; Ridley and Mengler, 2000) or by low-pressure boiling whereby $\mathrm{H}_{2} \mathrm{~S}$ escapes into the gas phase, forming epithermal gold veins (Drummond and Ohmoto, 1985; Spycher and Reed, 1989). Second, the reduction of a mildly oxidized gold-rich (e.g., magmatic) fluid by reaction with organic carbon (or mixing with methane) can explain gold precipitation, commonly in association with other redox-sensitive elements such as Sb or As. This mechanism is typical for sediment-hosted gold deposits, from amphibolite-facies metasediments in the thermal aureoles of granitoid intrusions 


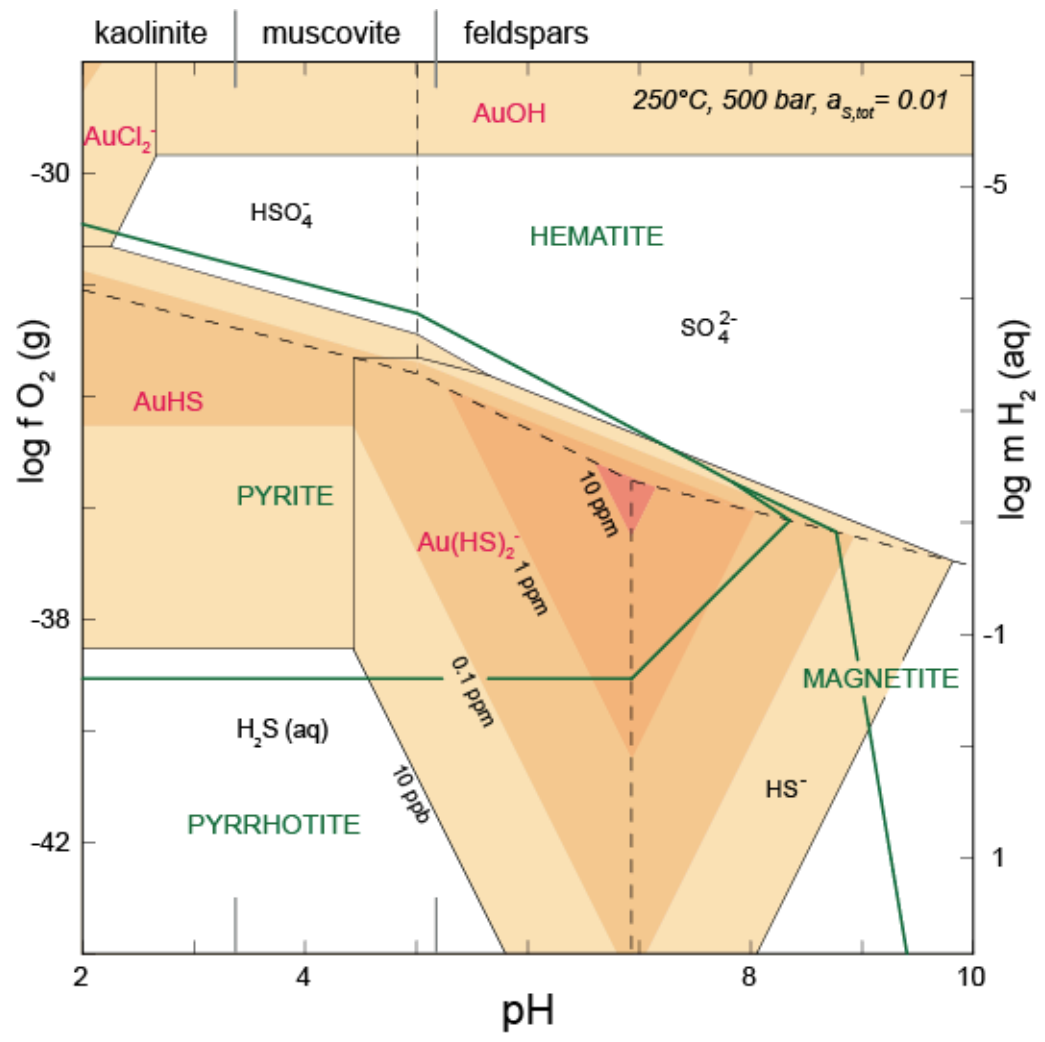

Fig. 6: Aqueous Au-solubility at $250^{\circ} \mathrm{C}$ and 500 bar (dashed contours in ppm, assuming $a_{A u}=1$ ) in aqueous fluids with a total sulfur activity of 0.01, overlain on predominance boundaries of aqueous sulfur species (dotted) and mineral stabilities in the $\mathrm{Fe}-\mathrm{S}-\mathrm{O}-\mathrm{H}$ system (solid lines). Calculated based on experimental data by Stefánsson and Seward (2004), Akinfiev and Zotov (2001, 2010) and thermodynamic data referenced in Figure 4.

(Wall et al., 2004) to epithermal deposits of Carlin-type (Cline et al., 2005; Muntean et al., 2011). In this environment, most of the gold can be captured in arsenious pyrite, whereby surface adsorption at conditions of native gold undersaturation may prevail (Simon et al., 1999). As a third possibility, complete oxidation of a sulfide-rich black-smoker fluid by mixing with oxygenated seawater can explain the deposition of gold in volcanogenic massive sulfide deposits (Large, 1992; Hannington et al., this volume).

\section{Metal Source Regions vs. Ore Deposition Sites}

Fluid - rock reaction in the rock-dominated source region of an ore-forming hydrothermal systems contrast with those at the site of ore deposition, requiring a focussed flux through a limited rock volume resulting in fluid-dominated conditions. This imposes mass-balance constraints limiting the final grade of an ore deposit, depending on the reactions driving ore mineral precipitation.

\section{Source region characteristics}

The concentrations of $\mathrm{Cu}, \mathrm{Pb}, \mathrm{Zn}$ and other scarce metals in common crustal rocks such as granite, shale or basalt vary within about one order of magnitude. This variation is small compared with the enrichment factors of 100 to 10,000 required to convert a rock into an economic ore deposit (Table 1). Metal solubilities vary over an even greater range, with experimental thermodynamic data and observations of natural brines indicating variations in metal concentration ranging over at least 5 orders of magnitude (Fig. 5), or even 8 orders if low-salinity meteoric groundwaters are included.

The characteristics of source rocks impose chemical conditions that can enhance or discourage leaching of metals from them, but their original metal content is probably not the limiting factor in most instances. Considering mass-balance alone, a small fraction of the crust affected by ore-forming hydrothemal systems commonly contains enough metal for even the largest ore deposits. For example, the basement beneath the Irish Midlands comprises some 100 '000 $\mathrm{km}^{3}$ of upper-crustal basement rocks that were permeated by 
saline brines during the late Paleozoic (Russell et al., 1981), yet a small fraction of a few 100 $\mathrm{km}^{3}$ of siliclastic metasediment are sufficient to source the $\mathrm{Pb}$ and $\mathrm{Zn}$ accumulated in all economic $\mathrm{Pb}-\mathrm{Zn}$ deposits in this province (Wilkinson et al., 2005). Similar order-ofmagnitude considerations can be applied to sediment-hosted, orogenic, magmatichydrothermal and even orthomagmatic ore systems (e.g., Arndt et al., 2005). Thus, any medium-sized pluton of normal granodiorite contains enough $\mathrm{Cu}$ to produce a large porphyry copper deposit (Dilles, 1987).

Metal abundance at source may become decisive, however, where physical and chemical conditions allow very high metal solubility in hydrothermal fluids and if metal activity is lowered in solid solutions or a metal-undersaturated melt phase. Notably in magmatic systems, where the activity of economic trace metals dissolved in melt is much lower than one, a pre-enrichment by fractional crystallization or admixture of a metal-rich melt phase would favor subsequent hydrothermal ore formation.

Quantitiative studies of metal-source regions of specific non-magmatic ore systems are rare compared to studies of ore deposits (e.g., Heinrich et al., 1995, for Mt. Isa copper; Wilkinson et al., 2005, for Irish Pb-Zn deposits). Even though we do not generally advocate the oncepopular concept of pre-enriched 'source beds' as a first-order ingredient for ore formation (Knight, 1957), there is a need for systematic investigations of source processes. Metal leaching is not determined by metal availability and bulk fluid - rock equilibria alone, but also by the mineralogical form of dispersed metals affecting their kinetic reactivity at the grain scale. For example, in the Canadian uranium ore systems, only the fraction of $U$ contained in decomposing monazite of basement rocks under the Athabasca basin is accessible to low-temperature leaching (Hecht and Cuney, 2000). Similarly in lowtemperature copper ore systems, the presence of reactive volcanic glass is probably more important than the slight enrichment of $\mathrm{Cu}$ in basaltic rocks compared to average crust (Brown, this volume). In

\section{Ore deposition and wall-rock alteration}

Sites of ore deposition are characterized by fluid - rock reactions in which integrated fluid flux is high compared with the quantity of reactive wall rock. Hydrothermal alteration along veins (zones of metasomatic reaction; e.g., Fig. 2D) is the characteristic evidence that fluid chemistry imposed its chemistry on host rocks that were initially out of thermodynamic equilibrium with the invading ore fluid (Reed, 1997). Ore-related alteration usually leads to complete conversion of host rocks to a small number of new minerals, i.e., a fluid-dominated assemblage of high thermodynamic variance. The chemical disequilibrium between advecting ore fluid and local wall rocks can drive metal deposition by reducing ore mineral solubility. For example, a solubility decrease may result from changing $\mathrm{pH}$ by alteration of feldspars to sheet silicates (reversing eq. 3 or 5 by fluid cooling in magmatic systems, leading to phyllic or 'greisen' alteration), or by dissolution of carbonate rocks to form skarn deposits (Baker et al., 2004; Meinert, this volume). Pyritization of Fe silicates in mafic wall rocks removes sulfur from metamorphic ore fluids, which can de-stabilize gold-bisulfide complexes and lead to economic gold precipitation (Phillips and Groves, 1983; Ridley et al., 1996).

The efficiency of ore metal deposition is limited by the mass balance between the reactive components in the advected fluid and the local rock. Final ore grade therefore depends not only on a thermodynamic driving force (a solubility gradient) but also on the quantities of essential reaction partners in the multicomponent fluid - rock systems. Even mineral precipitation by simple cooling is limited by the balance between steep temperature gradients (favoring localized ore deposition) and heat advection by the fluid itself (opposing its cooling in rocks of low thermal conductivity), as discussed in the classic paper by Barton and Toulmin (1961). There is ample evidence that large-scale hydrothermal metal transport 
is common in the Earth's crust, but only rarely leads to economic ore deposition. The following examples illustrate these points.

The Salton Sea geothermal system contains millions of tonnes of $\mathrm{Zn}$ dissolved in a slowly convecting brine plume, enough to form a world-class sediment-hosted zinc deposit, but neither thermal nor chemical gradients are adequate to cause localized deposition of sphalerite (Williams and Mckibben, 1989; Cathles and Adams, 2005). In magmatichydrothermal porphyry deposits, the concentrations of lead and zinc analyzed in ore fluid inclusions is of similar magnitude as that of copper, but lead and zinc usually pass through the vein network without precipitation, for lack of a driving force for solubility reduction (Heinrich, 2006). In the porphyry environment, galena and sphalerite precipitate only where fluids come in contact with carbonate rocks that neutralize the fluids. Their precipitation efficiency in carbonate-replacement deposits is additionally limited by sulfur availability in the ore fluid (Catchpole et al., 2011; 'Cordilleran type', Tab. 2). Even when acid neutralization by feldspar alteration alone drives ore-metal precipitation, as in disseminated tin deposits ('greisen-type' ores of cassiterite, $\mathrm{SnO}_{2}$ ), the maximum ore grade is limited to $\sim 1 \mathrm{wt} \% \mathrm{Sn}$, by the mass-balance between reactive feldspar in the rock and the total concentration of acidity advected by the fluid (Heinrich, 1990; Halter et al., 1996).

\section{Hydrothermal Ore Formation in Sedimentary Basins}

Mineral deposits in sedimentary basins, our main source of $\mathrm{Pb}$ and $\mathrm{Zn}$, occur as either Missisippi-Valley Type (replacing lithified carbonate-rich rocks) or stratiform clasticsediment hosted deposits (loosely called 'sedex', even though they are more commonly syndiagenetic hydrothermal rather than sedimentary-exhalative products; Leach et al., 2005a). Basins also contain a significant portion of the world's $\mathrm{Cu}$ resources, including the singlelargest deposits of this metal, which exceed even the largest porphyry-copper deposits in grade and tonnage. Silver and cobalt are important by-products in many sediment-hosted copper deposits. Sedimentary basins also host the main U resources of the world, as exemplified by the sandstone-hosted U-V-deposits discussed above and the giant unconformity-related uranium deposits of Proterozoic age (Kyser, this volume).

In this section we briefly speculate on the compositional separation of sediment-hosted $\mathrm{Cu}-$ (-Co-Ag...) and Pb-Zn-(-Cd-Ag-F-Ba...) deposits. These two deposit groups are discussed in detail by the respective chapters of McGoldrick and Wilkinson, and A. Brown, this volume. Despite consistent differences in mineralogy and geological appearance, it is still not clear why $\mathrm{Pb}-\mathrm{Zn}$ and $\mathrm{Cu} \pm \mathrm{Co}$ deposits are compositionally distinct with only limited overlap (Gustafson and Williams, 1981; Hitzman et al., 2005; Leach et al., 2005a).

All sediment-hosted $\mathrm{Cu}$ and $\mathrm{Pb}-\mathrm{Zn}$ deposits formed in marine basins with a record of evaporitic sedimentation, indicating hot arid conditions and providing a source of moderately to highly saline brines with high chloride for metal complexation. Cu deposits are mostly associated with intracontinental rifts filled with clastic sediments and volcanic rocks, whereas $\mathrm{Pb}-\mathrm{Zn}$ deposits mainly occur in marine platform carbonates of extensive intracontinental basins (MVT) or in shelf-regions of passive continental margins (stratiform deposits). Typical temperatures of ore deposition are between 50 and $120^{\circ} \mathrm{C}$ for sedimenthosted $\mathrm{Cu}$ deposits and replacive (MVT) $\mathrm{Pb}$-Zn-deposits, and may reach $200^{\circ} \mathrm{C}$ in stratiform $\mathrm{Pb}-\mathrm{Zn}$ deposits..

Potential metal-source volumes include immature clastic sediments, basin-filling volcanics as well as the fractured continental basement underlying the ore-bearing sedimentary basin (Boiron et al., 2010). Although continental redbeds and volcanic rocks are a typical component of the sediment package underlying $\mathrm{Cu}$ deposits, their hematitic mineralogy is a product of ore-related fluid flow and not necessarily a source-rock characteristic that differentiates them from the $\mathrm{Pb}-\mathrm{Zn}$ deposits. Even in high-salinity fluids, sulfide solubilities are so low that adequate metal concentrations are difficult to achieve if the fluids contain a 
significant amount of reduced sulfur (Fig. 4). A hydrological process driving fast fluid flow seems essential for $\mathrm{Pb}-\mathrm{Zn}$-deposits to become local or district-scale thermal anomalies (Cathles and Adams, 2005). Tectonic uplift of the basin margin, compaction dewatering, tectonic pumping or thermal convection through basin and basement have all been invoked, for both the $\mathrm{Pb}-\mathrm{Zn}$ and the $\mathrm{Cu}$ systems. A basic geochemical difference between $\mathrm{Cu}$ and $\mathrm{Pb}$ Zn deposits seems to be related to the host-rock alteration associated with the oredepositional environment. $\mathrm{Pb}-\mathrm{Zn}$ deposits hosted by carbonate-bearing sequences show evidence for extensive carbonate dissolution, indicating moderately acid but not necessarily highly oxidixing ore fluids transporting $\mathrm{Pb}$ and $\mathrm{Zn}$. By contrast, $\mathrm{Cu}$ deposits and their fluid pathways show evidence of active footwall oxidation ('red rock alteration') by the metalintroducing fluid, even in higher-temperature variants such as the native copper deposits of Michigan (Brown, this volume) or the hematite-carbonate fracture zones thought to feed the metasediment-hosted copper deposit at Mount Isa.

New insight has come from analyses of fluid inclusions in Mississippi Valley-type ore systems, indicating that sphalerite deposition was effected by pulses of anomalously metalrich brines (Pb up to 200 ppm, Zn to 1000 ppm; Stoffell et al., 2008; Wilkinson et al., 2009; Fig. 5). Some systems show geological and isotopic evidence that the fluids permeated deeply through basement rocks beneath the ore-hosting sedimentary basin (Russell et al., 1981; Wilkinson et al., 2005). Based on thermodynamic equilibrium calculations (Sverjensky, 1986; Tornos and Heinrich, 2008; Hennings et al., 2012), we speculate that sediment-hosted $\mathrm{Pb}$-Zn-deposits are formed from deeply circulating fluids buffered by pyrite - magnetite assemblages in basement rocks, which creates mildly reduced brines with variable excess of $\mathrm{Pb}$ and $\mathrm{Zn}$ compared to their overall low sulfur content. As a result, $\mathrm{Pb}-\mathrm{Zn}$ deposition in overlying sedimentary basins is dependent on a local sulfur source at the site of ore deposition, such as a $\mathrm{H}_{2} \mathrm{~S}$-rich gas trap (Jones and Kesler, 1992), or the biogenic or thermogenic reduction of sulfate (Wilkinson et al., 2005; Anderson, 2008; Thom and Anderson, 2008). By contrast, a decisive ingredient for $\mathrm{Cu}-(-\mathrm{Ag}-\mathrm{Co})$ ore formation may be a fluid that originates more directly from the oxygenated surface environment and maintains mildly oxidizing redox conditions, allowing effective $\mathrm{Cu}(+\mathrm{I})$ transport even at low temperatures (Brown, this volume, fig. 7). Ore deposition in this case depends on an effective reductant (such as solid carbonaceous matter in black shales or a mobile form of hydrocarbon; Hitzman et al., 2005), usually assisted by preexisting diagenetic pyrite which contributes to $\mathrm{Cu}$-sulfide precipitation based on textural and sulfur-isotopic evidence (Brown, this volume).

Iron-oxide hosted $\mathrm{Cu}-\mathrm{Au}-\mathrm{U}-\mathrm{REE}$ deposits and unconformity-related U-(Au-Pt-Pd) deposits (Table 2) share some ingredients with this interpretation of sediment-hosted copper ore formation. In the first case, a magmatic heat source may be the driver for an otherwise similar fluid-chemical process (Barton, this volume), although other authors consider a magmatic fluid input to the $\mathrm{Cu} \pm \mathrm{Au}$ budget as essential (Williams et al., 2005). Unconformity-related uranium deposits are enriched in other redox-sensitive elements including Mo, As, Se, Co, V, Au, Pt and/or Pd, elements that also occur in sediment-hosted copper deposits. They co-precipitate with $U$ by reduction to a lower valence state, at a sharp reduction front between an oxidized cover sequence (e.g., sandstone basins) and reduced basement rocks (e.g., carbonaceous phyllites), usually localized by post-depositional faults age (Wilde and Wall, 1987; Boiron et al., 2010; Cuney, 2010; Kyser, this volume).

\section{Hydrothermal Ore Systems in the Oceanic Realm}

Volcanogenic massive sulfide (VMS) deposits are high-grade metal accumulations associated with submarine magmatic rocks. These mineral deposits have profoundly influenced prehistoric metal extraction technology (e.g., Cyprus) and provided evidence for submarine hydrothermal activity well before black smokers and active seafloor hydrothermal systems were discovered (Stanton, 1955, and earlier Japanese workers; 
Solomon and Walshe, 1979; Scott, 1997; Franklin et al., 2005; Hannington et al., 2005). Today, ocean floor activity is recognised as Earth's most important hydrothermal transport process, in terms of heat and mass transfer between the Earth's interior and the hydrosphere (German and Von Damm, 2003). The process is dominated by seawater convection, driven by the heat of generally volatile-poor magmas emplaced at oceanic spreading centers. Compared to their global geochemical impact on the composition of ocean water and the composition of oceanic crust, however, the importance of mid-ocean ridge hydrothermal systems in generating economic ore deposits is rather small. Sulfides precipitated in black smokers is usually ephemeral, because the sulfides are rapidly redissolved by today's oxygenated seawater. The potential for preservation is further diminished by the low rate of sedimentation to cover and protect them, and the likelihood that they are subducted over geological timescales (Hannington et al., 2005).

Submarine hydrothermal systems related to arc volcanoes and back-arc basins are more important ore-forming environments, for several reasons. Some show clear evidence for the involvement of magmatic fluids, in addition to convecting seawater. Magmatic fluids added by subduction of hydrated oceanic crust are likely to increase the efficiency of ore formation. With the presence of thinned continental crust, they contribute to the polymetallic composition of arc-related sulfide orebodies $(\mathrm{Pb}, \mathrm{Au}, \mathrm{Cu}, \mathrm{Zn}$; Yang and Scott, 1996; De Ronde et al., 2005; Hannington et al., 2005). Higher-salinity fluids (e.g., of magmatic origin) also affect the hydrology of VMS ore deposition, and may be key to the formation of large sheet-like orebodies from negatively buoyant brines settling in local depressions on the ocean floor (Solomon and Quesada, 2003). Indeed, the majority of large massive sulfide deposits that are currently exposed on land were formed in association with submarine andesitic or bimodal volcanism, commonly close to acid volcanic centers. Arcrelated hydrothermal systems generally operate at shallower water depth compared to ocean ridge systems, which favors fluid phase separation and the generation of hypersaline brines. Moreover, proximity to continents improves the potential for preservation thanks to a protective sedimentary cover above newly formed deposits, and it increases the chance of later accretion, obduction and eventual exposure of deposits on land (Scott, 1997; Hannington et al., 2005). For these reasons, recent submarine sulfide deposits in back-arc settings are currently attracting greatest attention from exploration companies.

The polymetallic nature of volcanogenic massive sulfide deposits reflects the strong temperature dependence of sulfide solubility. Sharp temperature gradients at the seawater interface provide the dominant driving force for wholesale precipitation of pyrite and base metal sulfides to form high-grade deposits. At the deposit scale, metal zoning within deposits confirms that temperature is the key factor controlling ore metal deposition, with $\mathrm{Cu}$ enrichment in the hot feeder veins and near the center of mound-like orebodies and enrichment of more soluble $\mathrm{Pb}$ and $\mathrm{Zn}$ closer to the cold seawater interface. The deposition of massive sulfide is further enhanced by kinetically suppressed silica precipitation during rapid cooling and dilution of the ore fluids by ambient seawater (Hannington, this volume).

\section{Magmatic-Hydrothermal Ore Systems}

Magmatic-hydrothermal ore systems on land created our main resources of $\mathrm{Cu}, \mathrm{Mo}, \mathrm{Sn}, \mathrm{W}$, $\mathrm{In}, \mathrm{Re}$ and a significant source of $\mathrm{Au}, \mathrm{Ag}, \mathrm{Pb}, \mathrm{Zn}$ and other minor and rare metals. Deposit formation involves a succession of processes, which includes the partitioning of ore-forming components from a silicate melt into a saturating fluid phase as a key step (Hedenquist and Lowenstern, 1994; Richards, 2011a).

Porphyry-type and epithermal $\mathrm{Cu}$, Mo and Au deposits are the focus of this section (Sillitoe, 2010). This family of ore deposits is associated with hydrous magmas of intermediate silica content, in contrast to magmatic-hydrothermal systems in highly evolved granites giving rise to Sn-W deposits and pegmatite-related ores (discussed by Linnen et al., this volume). Figure 7 summarizes the geological context of porphyry-type and epithermal ore deposits 
(detailed in Cooke et al., Saunders et al., and Kissin and Mango chapters). A chain of processes in vertically extensive, crustal-scale magmatic-hydrothermal systems can explain the range of globally recurrent ore deposit types and their characteristic metal endowments (Fig. 7).

Fig. 7. Schematic illustration of the geological components, ore types and processes in crustal-scale magmatic-hydrothermal systems, combining aspects from Dilles (1987) Hedenquist and Lowenstern (1994) and Hill et al. (2002). Porphyry copper deposits form in a dense network of hydrofractures (red) around dikes and stocks above the roof of hydrous magma chambers, by precipitation of sulfides and gold from single-phase or more commonly two phase fluids of coexisting hypersaline liquid (brine) and vapor. Au-rich varieties predominate at shallow levels (1-3 km below surface) while porphyry deposits formed as deep as $8 \mathrm{~km}$ are generally $\mathrm{Cu} \pm$ Mo dominated and Au-poor.

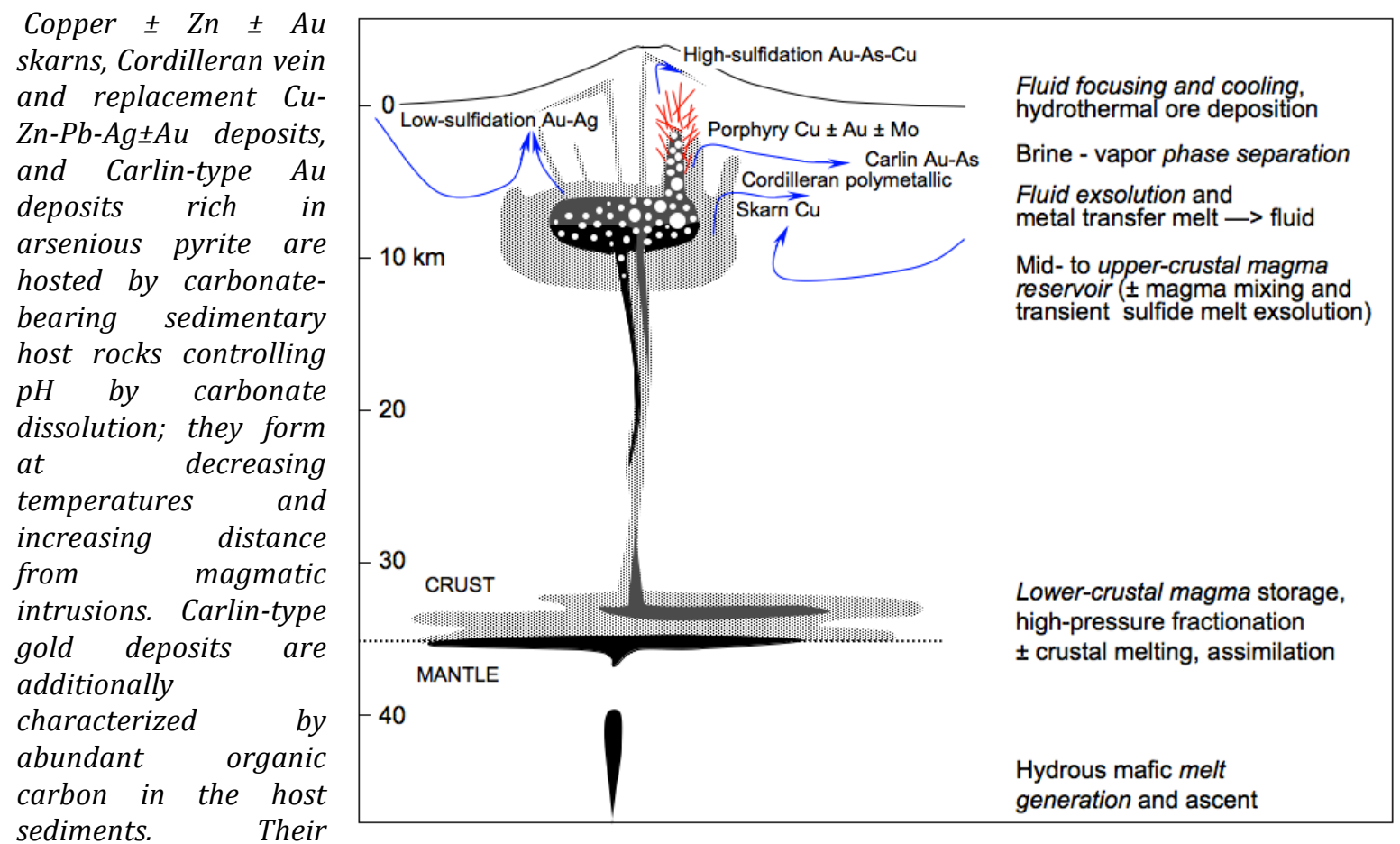
sediments. Their

formation temperature and the low salinity of ore fluids with liquid-like density overlap with fluid properties in other epithermal precious-metal deposits. High-sulfidation epithermal deposits are characterized by intense acid leaching, sulfate and clay alteration caused by hot low-density magmatic vapor, typically preceding the main stage of ore deposition by low-salinity aqueous liquid. Lowsulfidation epithermal deposits are generally more distal to intrusions and are characterized by nearneutral fluids causing feldspar - muscovite alteration, with a greater proportion of convecting meteoric water and a less obvious magmatic fluid input.

\section{Melt Generation, Magma Storage and Ascent}

Large magmatic-hydrothermal provinces typically comprise several deposits of one or several types but similar age (Wilkinson and Kesler, 2009; Sillitoe, 2010). These ore provinces reflect tectonomagmatic settings giving rise to hydrous (usually amphibolephyric) magmas that invariably have a subduction signature in their trace-element composition, including variable enrichment in mantle-fluid elements such as $\mathrm{Pb}, \mathrm{Ba}, \mathrm{Rb}, \mathrm{Sr}$ and depletion in high-field strength elements such as Ti, Zr and Y (Richards, 2003; Candela and Piccoli, 2005; Rohrlach and Loucks, 2005). Magmas producing major porphyry and epithermal ore provinces in the Circum-Pacific and Alpine-Himalayan belts are driven by concurrent subduction of oceanic lithosphere beneath an active continental margin (e.g. Chile - Peru, Philippines, Balkan - Iran). However, a growing number of world-class ore 
provinces are recognized to owe their subduction flavor to more ancient events, which chemically prepared the lithospheric mantle for later hydrous melting driven by extensional tectonics (Richards, 2011a). For example, Eocene magmas forming Bingham Canyon and the world's premier molybdenum-porphyry province in the SW-USA were interpreted to be fertilized by Proterozoic mantle metasomatism (Pettke et al., 2010). Incipient extension of this old and multiply accreted craton may also have contributed to the formation of roughly coeval gold deposits in the Great Basin, including Carlin (Emsbo et al., 2006). The world's premier tin province in Bolivia and southern Peru is characterized by repeated partial melting of reduced sediments, producing magmas from which $\mathrm{Sn}(+\mathrm{II})$ complexes are readily partitioned into fluids for later precipitation as hydrothermal $\mathrm{Sn}(+\mathrm{IV}) \mathrm{O}_{2}$ (cassiterite; Lehmann et al., 1990)

Even along arcs with long-lasting subduction magmatism, the formation of major deposits is typically confined to limited segments and short time periods of a few million years. Structural evidence and plate-scale tectonic reconstructions indicate that segments and periods of successful ore formation are characterized by a compressional state of the crust and lithosphere, favoring the formation of large fractionating magma chambers in the lower crust and preventing volcanic eruption and uncontrolled loss of volatiles in the upper crust (Rohrlach and Loucks, 2005; Sillitoe, 2010). Empirically, most productive porphyry ore provinces are driven by magma series exhibiting an 'adakite-like' trend of increasing $\mathrm{Sr} / \mathrm{Y}$ and depleted HREE (Richards, 2003). This geochemical signature is not caused by slab melting but reflects either assimilation of thickened garnet-bearing lower crust in areas of compressive flat-slab subduction (Kay and Mpodozis, 2002), or storage of mantle melts in large lower-crustal sills leading to high-pressure fractionation (amphibole-dominated but plagioclase-absent; Rohrlach and Loucks, 2005; Richards, 2011b). Both processes are favored by compressive horizontal stress in the lithosphere.

Whether source composition directly affects the later mineralization potential of magmas is unclear, although it is commonly implied. Large global metal provinces such as the Mo province in the SW-USA are suggestive of large-scale metal pre-enrichment in the lithospheric mantle or lower crust, but limited evidence from bulk compositions of magmatic rocks or melt inclusions has not clearly separated source effects from metal enrichment due to fractional crystallization of the magmas. In porphyry-copper mineralising magma suites, copper as well as sulfur concentrations are generally highest in the most mafic and mantle-dominated magmas and melt inclusions, and become depleted by fractional crystallization or mixing with more felsic magmas (Hattori and Keith, 2001; Halter et al., 2005). Copper and probably gold are largely incompatible with magmatic silicate and oxide phases and can become enriched in acid resudual melts (Mustard et al., 2006), but strongly fractionate into any solid or molten sulfide phase (Jugo et al., 1999; Halter et al., 2005), which probably explains the $\mathrm{Cu}-\mathrm{Au}$ depletion seen in most fractionating magma suites. Unusually oxidizing conditions in the melting region created by subduction fluids (Kelley and Cottrell, 2009), will increase the sulfate/sulfide ratio and total sulfur solubility (Carroll and Rutherford, 1985), which could be a decisive factor in generating Sand metal-enriched (especially Au-rich) but sulfide-undersaturated silicate melts favoring later $\mathrm{Cu}$ and $\mathrm{Au}$ accumulation (Hattori and Keith, 2001; Mungall, 2002; Richards, 2011a).

\section{Fluid Exsolution and Element Transfer from Melt to Fluid}

Magmatic-hydrothermal ore formation depends on the generation of a large and focused flux of metal- and sulfur-rich magmatic volatiles to the upper crust. For selected porphyrycopper deposits, the total metal resource, the concentration of ore metals in magmatic ore fluids, and plausible assumptions about the original content of metals in the magma, allow a mass-balance estimate of required quantities of source magma and fluid (Dilles, 1987; Ulrich et al., 1999; Cloos, 2001). Minimum required magma volumes typically range from a few tens to $100 \mathrm{~km}^{3}$. These estimates indicate that a rather small fraction of the total volume of a large mid- to upper-crustal batholith is adequate for forming a world-class ore 
deposit. In some cases, this conclusion can be confirmed by geological mapping of zoned batholiths (in areas exposed by later tilting; Dilles, 1987) or is indicated by large magnetic anomalies (Krahulec, 2010). Such evidence, and high concentrations of ore metals in magmatic fluid inclusions (Eastoe, 1982; Audétat et al., 2008) confirm that fluid saturation from an upper-crustal magma chamber is a key step in large-scale metal enrichment.

Separation of a minor amount of $\mathrm{CO}_{2}$-dominated fluid from ascending volatile rich magmas may start at lower- to mid-crustal depth (Carroll and Webster, 1994; Lowenstern, 2001; Zajacz and Halter, 2009). Copious fluid saturation sets in with weakly $\mathrm{CO}_{2}$ bearing and moderately saline aqueous fluid of intermediate ('supercritical') density, as indicated by experimental data and derived modeling (Candela and Holland, 1984; Cline and Bodnar, 1991; Candela and Piccoli, 2005) and limited fluid-inclusion observations from deeply exposed plutonic environments (Audétat et al., 2008; Hennings et al., 2012). These deep single-phase aqueous fluids also contain variable $\mathrm{H}_{2} \mathrm{~S}$ and $\mathrm{SO}_{2}$, depending on water pressure and redox potential of the source magma (Carroll and Webster, 1994; Giggenbach, 1997). Partition coefficients for metals forming stable chloride complexes increase with $\mathrm{Cl}$ availability (Candela and Piccoli, 2005), and relatively dense hydrous fluids separating from magma at pressures $>1 \mathrm{~kb}$ are most likely to contain high $\mathrm{Cl}$, S as well as high ore metal concentrations (cf. Cline and Bodnar, 1991). In sulfur-rich mafic magmas, the transfer of Au and possibly $\mathrm{Cu}$ to the fluid is enhanced by sulfide complexation, compounded by elevated alkali concentration in S-rich fluids (Zajacz et al., 2010). Initially oxidised sulfur in the melt may be reduced to $\mathrm{H}_{2} \mathrm{~S}$ during early magnetite saturation, thereby contributing to subsequent gold extraction into the magmatic fluid (Sun et al., 2004).

Fluid inclusions at the base of major porphyry copper deposits have intermediate density and low to moderate salinity, contain high $\mathrm{S} \pm \mathrm{CO}_{2}$ concentrations, up to weight percent levels of copper and ppm-levels of $\mathrm{Au}$ (Seo et al., 2009). However, the relative importance of $\mathrm{Cl}$ and $\mathrm{S}$ in generating the most effective ore fluids is still not established by quantitative experiments (Pokrovski et al., 2008). One of the causes for uncertainty stems from recent experimental evidence that $\mathrm{Cu}$ in natural quartz-hosted fluid and melt inclusions from deep high-temperature environments may be subject to selective post-entrapment diffusional exchange for outward-diffusing $\mathrm{H}^{+}$ions (Li et al., 2009b; Zajacz et al., 2009).

Inclusion evidence for direct separation of a Cu-rich hypersaline brine or salt melt from silicate melt has been recorded from several porphyry copper deposits (e.g., Harris et al., 2003). We interpret such brines as a local product of the shallow-level emplacement of volumetrically small porphyry stocks, rather than the more important source process in deeper magma chambers, generating a large quantity of low-salinity fluid that drives economic ore formation.

The physical process and the rate of fluid extraction from an upper-crustal magma reservoir is critical for fluid focusing and ore formation (Candela, 1991; Giggenbach, 1997; Candela and Piccoli, 2005). It may occur by dispersed bubble exsolution and ascent through large parts of the intrusions, driven by inward crystallization of the intrusions and progressive volatile enrichment in the melt as less-hydrous minerals crystallize ('second boiling'; Burnham and Ohmoto, 1980; Cline and Bodnar, 1991). Alternatively, fluid may exsolve and collect in cupolas at the highest point of the intrusion as a result of internal convection in the magma chamber (Shinohara et al., 1995; Cloos, 2001), prior to almost simultaneous emplacement of porphyry stocks, their fracturing and mineralization by near-explosive fluid expulsion towards the surface (Dilles, 1987; Cathles and Shannon, 2007). Reconciling highprecision geochronology with physical modeling of these alternative or possibly concurrent processes, within the thermal constraints on the rates of magma chamber evolution, porpyry emplacement and ore formation, is an important challenge for current research (cf., Driesner and Geiger, 2007; Ingebritsen et al., 2010; Von Quadt et al., 2011). 


\section{Fluid Cooling, Decompression and Phase Separation}

The subsolidus evolution of magmatic fluids can be discussed by reference to the $\mathrm{NaCl}-\mathrm{H}_{2} \mathrm{O}$ model system (Fig. 8; Henley and Mcnabb, 1978; Hedenquist and Lowenstern, 1994; Williams-Jones and Heinrich, 2005).

At low pressures (at most $\sim 400$ bar), essentially salt-free vapor coexists with solid halite (region bounded by heavy green lines in Fig. 8). Phase relations and density variations above the vapor + halite region are characterized by a variable miscibility gap (black net in Fig. 8), separating low-salinity vapor of variable density from saline liquid that may reach halite saturation at 25 to $>60 \% \mathrm{NaCl}$, depending mainly on temperature. The critical curve for binary liquid + vapor (i.e., the crest of the miscibility gap indicated by the red line in Fig. 8 ), extends from the critical point of water to higher pressures and temperatures. It also swings to more saline compositions, allowing vapor at elevated pressure and nearmagmatic temperatures to reach salinities up to $\sim 20 \%$ salt. The presence of minor $\mathrm{CO}_{2}$ and $\mathrm{H}_{2} \mathrm{~S}$ will shift the miscibility gap towards higher pressure but does not change the topology of the phase diagram.

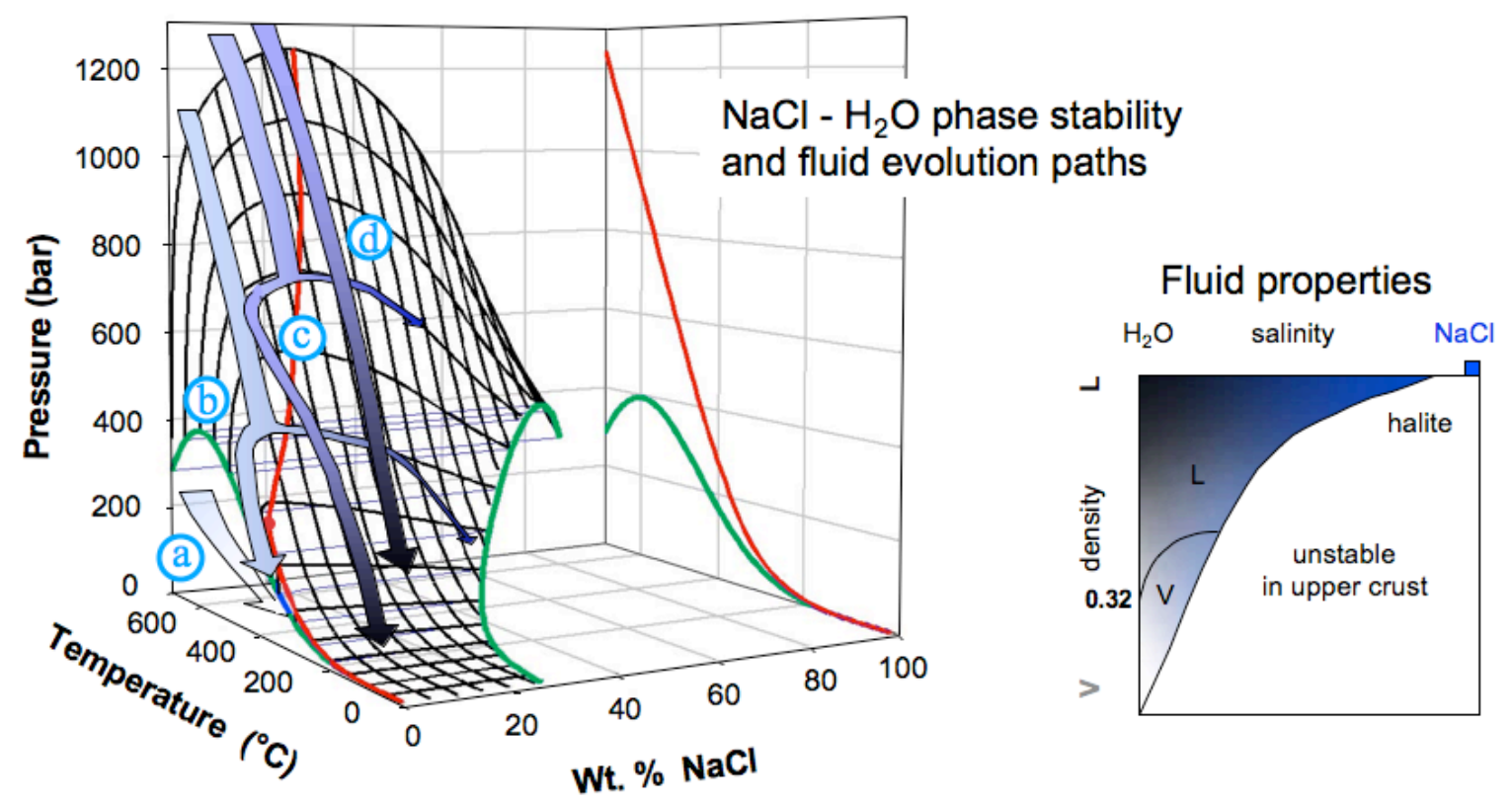

Fig 8. Phase diagram for NaCl- $\mathrm{H}_{2} \mathrm{O}-\mathrm{P}$-T from Driesner and Heinrich (2007), showing the limiting twophase liquid + vapor surface (black), the halite saturation surface (green) and the compositiondependent critical curve (red). Four possible fluid evolution paths of a cooling low-salinity magmatic fluid are indicated by arrows, emphasizing the effect of pressure upon phase state and density change. Degrees of darkness and blue color schematically indicate fluid density and salinity, respectively, varying from low-density vapor (white) to dense saline brine (dark blue) and low-salinity aqueous liquid (black; inset right; modified from Williams-Jones and Heinrich, 2005).

There is an intriguing difference between careful analyses of coexisting vapour and brine fluid inclusions from porphyry-type deposits, and well-controlled experiments carried out at magmatic conditions. Microanalysis of coexisting natural brine and vapor inclusions has shown that $\mathrm{K}, \mathrm{Fe}, \mathrm{Mn}, \mathrm{Zn}, \mathrm{Pb}$ and minor salt components fractionate with $\mathrm{NaCl}$ into the liquid phase, whereas $\mathrm{B}, \mathrm{S}, \mathrm{Cu}, \mathrm{As}, \mathrm{Sb}$ and $\mathrm{Au}$ are enriched to variable degrees in the coexisting vapor inclusions (Heinrich et al., 1999; Baker et al., 2004; Seo et al., 2009). Experiments at $800^{\circ} \mathrm{C}$ and pressures of $1-1.4 \mathrm{kbar}$, in the presence of melt, show that $\mathrm{Cu}$ and $\mathrm{Au}$ concentrate in the brine relative to the vapor, with relative partitioning into the vapor enhanced by the presence of reduced sulfur (Frank et al., 2011). Under sub-solidus 
conditions, Nagaseki and Hayashi (2008) and Pokrovski et al. (2008) show experimentally that copper can partition significantly to the vapour in the presence of sulfur, but the extreme copper enrichment found in natural vapor inclusions has not yet been reproduced by well-controlled experiments and may be a result of post-entrapment modification of fluid inclusions (Li et al., 2009b; Zajacz et al., 2009). Experiments at $1000^{\circ} \mathrm{C}$ and $1.5 \mathrm{kbar}$ (Zajacz et al., 2010) indicate that copper and gold solubility are a complex function of the concentration of chloride, sulfide as well as alkali concentrations in low density aqueous gases. There is little doubt however, that metals are effectively transported by vapor, and that their solubility in vapor increases with increasing vapor density (and therefore pressure), because hydration stabilizes metal species in the vapor phase (Williams-Jones and Heinrich, 2005).

\section{Fluid evolution paths at the porphyry to epithermal transition}

Distinct deposit types found in magmatic-hydrothermal systems, their fluid-inclusion characteristics and the temporal sequence of mineralization can be explained, to a first order, by different density - salinity paths of fluids moving through P-T space during ascent from their magmatic source towards the Earth's surface. Fluid chemistry and ore precipitation are controlled by cooling and decompression, as fluids are expelled from lithostatic conditions in the magma to hydrostatic conditions closer to the surface, where they can interact with meteoric water to variable degrees (Fournier, 1999). The depth of fluid exsolution from magma is likely to be the key to different evolution paths.

(a)
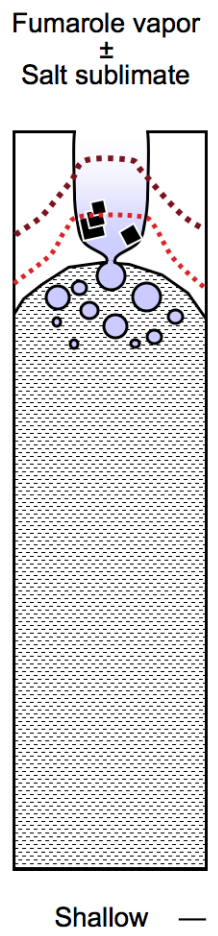

(b)

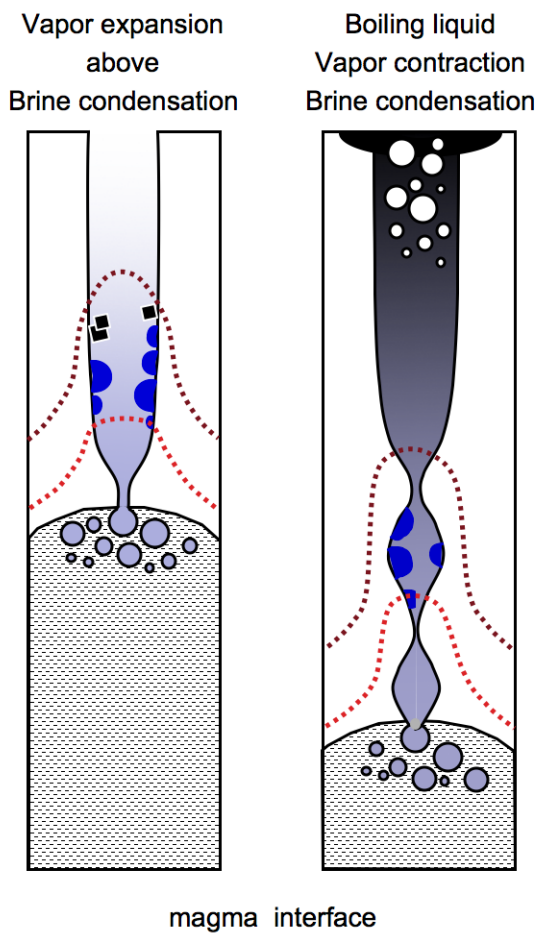

(d)

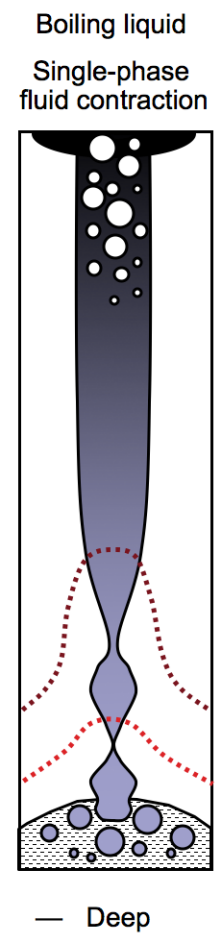

Fig. 9. Schematic representation of alternative physical evolutions of a lowsalinity magmatic fluid ascending from variable depths of its hydrous magma source, corresponding to the four P-T- $X_{\text {NaCl }}$ paths indicated in Figure 8 and using the same colour shading for density (darkness) and salinity (blue). Cooling between $\sim 650^{\circ} \mathrm{C}$ and $\sim 300^{\circ} \mathrm{C}$ is schematically indicated by the red and brown isotherms (dotted lines) to illustrate the alternatives of magmatic vapour

expansion in hot and shallow systems ( $A, B$, with or without brine condensation at depth), in contrast to vapor contraction when the low-salinity fluid cools at pressure in deep magmatic-hydrothermal systems $(C, D)$. Note that magmatic vapor that initially condensed out a brine at depth can subsequently contract to aqueous liquid that may eventually boil at shallow pressure (C; compare path c in Figure 8). Constrictions in the fluid columns indicate the transition from lithostatic fluid pressure in and above the magma chamber to hydrostatic pressure in veins extending to the surface. This transition occurs near the brittle-to-ductile transition of rocks, depending in turn on magma depth and heat advection by focussed fluid ascent. The distinct fluid evolutions may also succeed each other in time, as a magmatic system cools and the magma front retracts to greater depth. 
If hydrous magma is emplaced close to the Earth's surface, e.g., in the neck of a volcano, high-temperature fumarolic activity will be dominated by low-pressure vapor and salt sublimates, as indicated by path (a) in Figure 8 and shown as a schematic physical representation in Figure 9A. The vapor has such a low density that metal transport is minimal and only contains acid-generating volatiles including $\mathrm{SO}_{2}, \mathrm{H}_{2} \mathrm{~S}$ and $\mathrm{CO}_{2}$. If condensed or mixed with surface water, such fluids will cause barren acid alteration or, at slightly greater depth inside a volcano, may produce sulfide-free porphyry gold deposits by precipitating precious metal with magnetite (Vila and Sillitoe, 1991; Muntean and Einaudi, 2000).

Magmatic fluid exsolving from a magma chamber at a few kilometers depth will generally be a single-phase fluid of intermediate density and 2-13 (average 5) wt $\% \mathrm{NaCl}_{\text {eq }}$ salinity (Audétat et al., 2008). Depending on its P-T path during ascent, the fluid may intersect the two-phase surface and separate into hypersaline liquid (brine) and lower-salinity vapor. If the pressure drop is sufficient, the fluids may additionally saturate halite (solid $\mathrm{NaCl}$; reaching the green curves in Fig. 8), as indicated by enrichment of $\mathrm{KCl}$ in residual brine inclusions of shallow porphyry deposits (Cloke and Kesler, 1979). If the initial salinity of the single-phase fluid is less than $\sim 10 \%$, the two-phase curve is likely to be intersected on the vapor-side of the critical curve (path b in Fig. 8), so that a volumetrically small proportion of brine condenses from a predominant flux of vapor (Fig. 9B). Such an evolution towards vapor expansion is recorded by fluid inclusions in the central upflow zone of the zoned Bingham Canyon porphyry Cu-Au deposit (Landtwing et al., 2010). The steep P-T gradient resulting from vapor expansion is expected to force wholesale precipitation of $\mathrm{Cu}$ together with any dissolved $\mathrm{Au}$, due to the destabilization of hydrated metal complexes transported by the vapor. This process may explain why most Au-rich porphyry copper deposits were formed at shallow depths and low fluid pressure (Cox and Singer, 1988; Murakami et al., 2010).

Intersection of the two-phase curve at higher pressure (path c in Fig. 8) generates a denser vapor that, after physical separation from brine and cooling at elevated pressure, may again leave the two-phase surface and subsequently cross isochemically above the critical curve of the systems. Such a physical process, indicated in Figure 9C, can result during the later stages of cooling of a large magmatic-hydrothermal system (Driesner and Geiger, 2007) and may have important geochemical consequences. First, the vapor phase will be depleted in Fe, one of the dominant salt components fractionating into the residual brine. Second, the Fe-depleted but likely S-enriched vapor phase is ideally suited to transport high concentrations of S-complexed gold, in a fluid phase that becomes gradually denser and more liquid-like upon cooling (vapor to liquid contraction; Heinrich et al., 2004). Sulfur excess over chalcophile metals $(\mathrm{Cu}, \mathrm{Fe})$ will lead to selective deposition of $\mathrm{Cu}$-Fe-sulfides in gold-poor porphyry copper deposits at high temperature and greater depth, and is essential to permit effective transfer of sulfur-complexed gold in the vapor-derived aqueous liquid towards shallower environments of epithermal ore formation.

The magmatic fluid may also rise and cool entirely within the single-phase stability field, if fluid separation from the magma occurs at depth and if the fluid is cooled sufficiently at elevated pressure (Hedenquist et al., 1998), as indicated by path $d$ in Figure 8 and the sketch in Figure 9D. In this case, the compositional evolution will be dominated by mineral precipitation and alteration reactions. Such a path explains the dense fluids in deep porphyry deposits such as Butte (Rusk et al., 2008) and the characteristic liquid-dominated inclusion assemblages of Cordilleran-type ore systems and their typical camp-scale ore zonation from proximal $\mathrm{Cu}$ through $\mathrm{Pb}-\mathrm{Zn}$ to distal veins and replacement orebodies containing $\mathrm{Ag}, \mathrm{Au}$, As and/or Sb (Simmons et al., 2005; Bendezu and Fontbote, 2009; Catchpole et al., 2011). 


\section{Wall-Rock Alteration and Ore Mineral Precipitation}

Geochemical characteristics of wall rocks at the ore deposition site and the resulting alteration reactions the finally shape the diversity of ore deposit types and their metal endowment in porphyry - epithermal systems (Giggenbach, 1997; Reed, 1997; Sillitoe, 2010). With a given input fluid composition, iron-rich mafic to intermediate intrusions and volcanic host rocks, or their previously magnetite-altered counterparts, are particularly efficient at causing wholesale $\mathrm{Cu}-\mathrm{Fe}$-sulfide precipitation together with $\mathrm{Au}$ in porphyry-Cu$\mathrm{Au}$ deposits, due to reduction of $\mathrm{SO}_{2}$ to $\mathrm{H}_{2} \mathrm{~S}$ in the fluid and effective de-sulfidation of sulfidecomplexed metals (e.g., Arancibia and Clark, 1996; Ulrich and Heinrich, 2002). By contrast, Fe-poor quartzo-feldspathic and/or carbonate-rich sedimentary rocks at the deposition site are more conducive to precipitation of base metal sulfides, while Au stays in solution because acid-neutralization by felspar-to-muscovite alteration or carbonate dissolution tends to increase gold solubility (eq. 9; Fig. 6). Such gold remains transportable to low temperatures, until the fluid reaches a depositional trap, e.g. in sedimentary host sequences rich in organic reductant (e.g., Carlin trend; Muntean et al., 2011). Local saline fluids in equilibrium with such reduced host rock packages will be $\mathrm{Fe}^{2+}-$ rich, and their mixing with moderately oxidized, sulfur and gold-rich fluids from a deeper magmatic or possibly metamorphic source will lead to co-precipitation of $\mathrm{Au} \pm$ As with abundant pyrite (Kesler et al., 2005). Alternatively, focusing of similar fluids towards the surface can form classic lowsulfidation epithermal veins. These typically show vertically restricted bonanza-grade gold \pm silver zones, resulting from phase separation and partitioning of the gold-complexing sulfide ligand into the low-density vapor phase (Drummond and Ohmoto, 1985; Spycher and Reed, 1989; Henley and Berger, 2000; Simmons et al., 2005).

In summary, magmatic-hydrothermal systems are particularly effective engines for ore metal enrichment, because they comprise several steps of element separation among rocks, melts and multi-phase fluids, in an environment creating steep gradients in pressure, temperature and chemical conditions between hydrous magma and the Earth's surface. The broad range of deposit styles can be rationalized by a limited number of physical variables, which provide for 'chemical divides' leading to distinct metal enrichments.

\section{Ore Formation at the Earth's Surface}

In this final section, we introduce the processes forming important resources at the Earth's surface and at the ocean floor (Fig. 1c; Table 2), where atmosphere and hydrosphere interact directly with the uppermost part of the crust. As in hydrothermal ore deposits, the controlling factors are the structure and surface properties of minerals, element compatibility and fluid speciation controlling selective dissolution and precipitation. However, the processes grouped together here are more directly driven by climate, atmosphere composition, and the movement of open ocean and surface water as well as biological activity. Not surprisingly then, major ore deposit types in this group provide some of the most compelling evidence for significant variation in Earth's surface conditions, notably the increase of oxygen content in the atmosphere during the late Archean (Holland, 2005).

In the oceanic domain, major metal resources are formed from seawater without local hydrothermal contribution, even though the metals may originally have been leached by sub-seafloor hydrothermal activity. In modern oxic oceans, manganese released by black smokers does not precipitate as sulfide in VMS deposits, but is dispersed to distal chemical sediments by basin-scale ocean currents. Major manganese deposits mined today resulted from global events of changing ocean composition in combination with sea-level changes, affecting transgression and regression in restricted marginal-marine basins (Frakes and Bolton, 1992; Gutzmer et al., this volume). Ferromanganese nodules and crusts are precipitated directly from ambient seawater. They constitute an enormous untapped metal resource not only of $\mathrm{Mn}, \mathrm{Co}, \mathrm{Ni}$ and $\mathrm{Cu}$, but also of many technologically strategic elements 
including Mo, Li in nodules, and additionally $\mathrm{Ti}, \mathrm{Pt}, \mathrm{Zr}, \mathrm{Nb}, \mathrm{Te}, \mathrm{Bi}, \mathrm{W}$, Th and Rare Earth Elements (Lanthanides) in ferromanganese crusts (Grupe et al., 2001; Hein and Koschinsky, this volume). Marine phosphate deposits (phosphorites) form by biogenic carbonatefluorapatite precipitation at the sediment - water interface in marginal basins and shelf regions, where deep ocean water is upwelling over extended periods (Piper and Perkins, this volume). Lower oxygen levels in the Archean atmosphere kept ocean waters anoxic, such that $\mathrm{Fe}^{2+}$ from ocean-floor hydrothermal activity or continental sources remained soluble, up to the Paleoproterozoic when the partial pressure of oxygen in the atmosphere and in near-surface ocean waters rose with the onset of photosynthetic metabolism. Banded iron formations were deposited as chemical sediments, mostly in the period between 2.5 and $2 \mathrm{Ga}$ (Ramanaidou and Wells, this volume). They probably formed on shelf regions of proto-continents in stratified ocean basins with anoxic bottom water. These silica and Ferich chemical sediments provided the first step of large-scale iron accumulation, followed by secondary upgrading by meteoric water or low-temperature hydrothermal processes forming the most important iron ores mined today.

Evaporation of surface waters produces a range of salt deposits, depending on the starting composition and evaporation paths (Warren, this volume). Evaporite differentiation is one of the classic examples of 'chemical divides' explored by a pioneering study of multicomponent thermodynamic reaction modelling (Hardie and Eugster, 1970; Eugster and Hardie, 1975). Progressive evaporation of seawater, or of continental salt lakes dominated by marine aerosols, successively deposits gypsum, halite $(\mathrm{NaCl})$ and eventually potash (K) and magnesium salts. Continental surface waters with an initially small excess of bicarbonate compared with earth alkalis $(\mathrm{Ca}, \mathrm{Mn})$ will never saturate gypsum and may evolve towards precipitation sodium carbonate salts such as trona $\left(\mathrm{Na}_{3}\left(\mathrm{CO}_{3}\right)\left(\mathrm{HCO}_{3}\right) \cdot 2 \mathrm{H}_{2} \mathrm{O}\right.$; a strategic resource used for alumina beneficiation from bauxite). Lithium and borate salts are produced by evaporation of continental surface waters with a volcanic input.

On continental land surfaces, ore formation can be driven by weathering, again depending on the oxygen level of the atmosphere. Especially in humid (sub)tropical climates, weathering creates residual ore deposits in lateritic soils. Bauxite is our main aluminium ore and forms by complete hydrolysis of primarily Al-rich rocks such as anorthosites or extensively soluble clay-bearing carbonate rocks (Freyssinet et al., 2005 and this volume). Lateritic deposits of $\mathrm{Ni} \pm$ Co form by liberation of the metals from olivine in ultramafic rocks, contributing significantly to global $\mathrm{Ni}$ and Co supply besides sulfide deposits. At Phanerozoic $\mathrm{O}_{2}$ levels similar to todays, supergene enrichment of primary sulfide deposits has made the first ore deposits accessible to metal mining by prehistoric civilizations, because it can form native copper by oxidation of copper sulfide and removal of the soluble sulfate. Secondary upgrading is a major economic factor for many modern porphyry copper deposits. It occurs by in-situ vertical or small-scale lateral metal re-distribution, as a result of surface weathering (dissolution of primary $\mathrm{Cu}$ sulfides in the unsaturated zone) and reprecipitation of copper oxides, carbonates, silicates or secondary sulfides just below the water table (e.g. chalcocite $\mathrm{Cu}_{2} \mathrm{~S}$ precipitation at the contact to underlying less $\mathrm{Cu}$-rich sulfides such as chalcopyrite and pyrite). Biological mediation is essential to speed up the rate of selective metal transfer and secondary enrichment: sulfide oxidation in the unsaturated zone by Fe-oxidising bacteria, followed by reprecipitation assisted by sulfatereducing bacteria below the groundwater table (Ague and Brimhall, 1989; Sillitoe, 2005).

Mechanical redistribution of chemically resitive mineral grains by flowing surface water generates placer deposits of $\mathrm{Au}, \mathrm{Sn}$ (as cassiterite $\mathrm{SnO}_{2}$ ) and various gemstones including diamond (Groat et al., this volume). River and beach sands are the main source of Ti (rutile, ilmenite), $\mathrm{Zr}$ (zircon) and a significant source of Rare Earth Elements from monazite (Garnett and Bassett, 2005). In the anoxic surface environment of the Archean, pyrite and uraninite are interpreted to have been transported as refractory heavy minerals, forming 
giant placer accumulations that were later reworked and possibly upgraded by metamorphic fluid activity (Frimmel et al., 2005; Robb and Hayward, this volume).

\section{Back to the Future: Global Mineral Resources}

We tried to show in thie review that ore formation is an integral part of our planet's evolution and reflects varied combinations of large-scale tectonics with chemical interactions between the reduced hot interior of the Earth and its evolving atmosphere and hydrosphere. The largest and economically most significant ore deposits are extreme geochemical anomalies, not because of inherently anomalous or untypical processes, but because they require an optimized confluence, in space and time, of several geological processes that co-operate at multiple scales. The magnitude of mass transfer forming world-class ore deposits provides some of the most spectacular evidence that lithospherescale fluid flow through rocks is a characteristic of our planet. Ore deposits are therefore a research window to the physical and chemical evolution of the Earth, because the types of deposits change from the Archean to the Phanerozoic as a result of the chemical evolution and interactions of mantle, crust, ocean and atmosphere (Holland, 2005). So it would not be surprising if chemical reactions between sulfide surfaces and hydrothermal ore fluids held the keys to the origin of life on Earth (Russell et al., 2005).

Popular discussions about resources commonly ask, why we mine new ore deposits, rather than recycle all our metals? Extensive recent research has been devoted to assessing the stocks of metals in use today, to emphasize the ultimate aim of sustainable use of resources (e.g., Graedel et al., 2006). However, a great part of this stock is in long-term use (e.g., in building infrastructure) so that even complete recycling of easily separated metals like copper cannot meet the demand of industrialised countries today, let alone of future global society. Unless people in emerging economies are denied access to electricity and other infrastructure, comparable to that enjoyed by the industrialized countries today, finding and mining new copper resources is a necessity that cannot be avoided for many decades even assuming complete recycling of the waste becoming available. Similar arguments can be made for many other metals, including uranium.

So, will we run out of essential materials soon? Ores clearly are 'non-renewable' resources in the sense that their rate of geological accumulation does not keep pace with the rate of extraction and usage by human society. Estimates for gold show that we mine deposits about 17,000 times faster than they form and are preserved (Kesler and Wilkinson, 2009), and estimates for copper resources give a similar number. Nevertheless, known reserves have generally grown over time, despite the exhaustion of individual deposits, thanks to human innovation in extractive technology and in delineating previously unknown resources. In spite of recurrent warnings, the reserves of most important base and precious metals have been sufficient to supply at least a decade or two at current rates of mining, although finding new deposits has become more difficult and costly (Enders and Saunders, 2011), and their extraction will increasingly be limited by the use of land, water and energy. Both, economic and environmental costs are (to a first approximation) inversely related to the natural metal enrichment in an ore deposit. It will always be possible to extract metals from lower-grade resources, so 'running out' is not the real issue. Statistical modelling of average formation, burial and exposure rates (e.g., Kesler and Wilkinson, 2008) shows that undiscovered deposits exist in numbers, sizes and ore grades meeting demand for many centuries, even at relatively shallow depths of $1-3 \mathrm{~km}$ accessible by today's mining technology. Finding and mining these buried high-grade deposits - albeit scientifically and technically challenging and perhaps more costly - may become the more attractive option than using lower-grade ores at greater expense of energy and environmental resources. In any case, along with additional research to understand how the deposits form, we must do more far-field research to be able to detect deposits from geological and geochemical clues at greater distances from the deposits. We hope that this volume of Treatise on 
Geochemistry will bring a vital topic to the attention of the broad range of geoscientists, who are needed to meet this challenge.

Acknowledgements. This review builds on discussions over many years within both our groups at ETH Zurich and at the University of Maryland, including the interaction with graduate students in courses where we have presented this material in a similar structure. CAH would like to specially acknowledge (occasionally heated) discussions with Thomas Driesner, John Dilles, Vic Wall, Anthony Williams-Jones, John Walshe and his late mentor Mike Solomon; PAC would like to thank Phil Piccoli and Phil Blevin for their many discussions and critiques over the years, his many students and postdocs, and his mentor, Dick Holland - hastening to say that we will take all the blame for bias and shortcomings in this review. We also would like to thank Thomas Wagner and Tobias Schlegel for help with the construction of thermodynamic diagrams, and additionally Karin Siegel for part of the drafting. Excellent discussions with and reviews of the manuscript by Alex Brown, Steve Ingebritsen, Steve Kesler, Dave Leach, Steve Scott, Alan Thompson and Bruce Yardley are gratefully acknowledged.

\section{References}

Ague, J. J. and Brimhall, G. H. (1989). Geochemical modeling of steady-state fluid-flow and chemical reaction during supergene enrichment of porphyry copper- deposits. Economic Geology, 84, 506-528.

Ague, J. J. (2003). Fluid flow in the deep crust. Treatise on Geochemistry. 3, 195-228: Elsevier.

Akinfiev, N. N. and Zotov, A. V. (2001). Thermodynamic description of chloride, hydrosulfide, and hydroxo complexes of $\mathrm{Ag}(\mathrm{I}), \mathrm{Cu}(\mathrm{I})$, and $\mathrm{Au}(\mathrm{I})$ at temperatures of 25-500 degrees $\mathrm{C}$ and pressures of 1-2000 bar. Geochemistry International, 39, 990-1006.

Akinfiev, N. N. and Zotov, A. V. (2010). Thermodynamic description of aqueous species in the system $\mathrm{Cu}-\mathrm{Ag}-\mathrm{Au}-\mathrm{S}-\mathrm{O}-\mathrm{H}$ at temperatures of $0-600 \mathrm{~A}$ degrees $\mathrm{C}$ and pressures of 1-3000 bar. Geochemistry International, 48, 714-720.

Anderson, G. M. (2008). The mixing hypothesis amd the origin of Mississippi Valley-Type ore deposits. Economic Geology, 103, 1683-1690.

Arancibia, O. N. and Clark, A. H. (1996). Early magnetite-amphibole-plagioclase alteration mineralization in the Island Copper porphyry copper-gold-molybdenum deposit, British Columbia. Economic Geology, 91, 402-439.

Arndt, N. T., Lesher, C. M. and Czamanske, G. K. (2005). Mantle-derived magmas and magmatic Ni-Cu(PGE) deposits. In: Hedenquist, J. W., Thompson, J. F. H., Goldfarb, R. J. \& Richards, J. P. (eds.) Economic Geology 100th Anniversary Volume. 5-23: Society of Economic Geologists, Littleton CO.

Audétat, A., Pettke, T., Heinrich, C. A. and Bodnar, R. J. (2008). The composition of magmatichydrothermal fluids in barren and mineralized intrusions. Economic Geology, 103, 877-908.

Baker, T., Van Achterberg, E., Ryan, C. G. and Lang, J. R. (2004). Composition and evolution of ore fluids in a magmatic-hydrothermal skarn deposit. Geology, 32, 117-120.

Barnes, H. L. (1997). Geochemistry of Hydrothermal Ore Deposits, New York, Wiley, 972 pp.

Barnes, S.-J. and Lightfoot, P. C. (2005). Formation of magmatic nickel sulfide deposits and processes affecting their copper and platinum group element contents. In: Hedenquist, J. W., Thompson, J. F. H., Goldfarb, R. J. \& Richards, J. P. (eds.) Economic Geology 100th Anniversary Volume. 179-213: Society of Economic Geologists, Littleton CO.

Barton, P. B. and Toulmin, P. (1961). Some mechanisms for cooling hydrothermal fluids. U. S. Geol. Surv. Prof. Pap., 424-D, 348-352.

Bendezu, R. and Fontbote, L. (2009). Cordilleran epithermal $\mathrm{Cu}-\mathrm{Zn}-\mathrm{Pb}-(\mathrm{Au}-\mathrm{Ag})$ mineralization in the Colquijirca District, Central Peru: Deposit-scale mineralogical patterns. Economic Geology, 104, 905-944.

Bethke, C. M. (1986). Hydrologic constraints on the genesis of the Upper Mississippi Valley mineral district from Illinois Basin brines. Economic Geology, 81, 233-249.

Bierlein, F. P., Groves, D. I., Goldfarb, R. J. and Dube, B. (2006). Lithospheric controls on the formation of provinces hosting giant orogenic gold deposits. Mineralium Deposita, 40, 874-886. 
Boiron, M. C., Cathelineau, M. and Richard, A. (2010). Fluid flows and metal deposition near basement/cover unconformity: lessons and analogies from Pb-Zn-F-Ba systems for the understanding of Proterozoic U deposits. Geofluids, 10, 270-292.

Brimhall, G. H. and Crerar, D. A. (1987). Ore fluids: magmatic to supergene. In: Carmichael, I. S. E. \& Eugster, H. P. (eds.) Thermodynamic modeling of geological materials: Minerals, fluids and melt. 17, 235-321: Reviews in Mineralogy.

Burnham, C. W. and Ohmoto, H. (1980). Late-stage processes of felsic magmatism. Mining Geology Special Issue, 1-11.

Candela, P. A. and Holland, H. D. (1984). The partitioning of copper and molybdenum between silicate melts and aqueous fluids. Geochimica et Cosmochimica Acta, 48, 373-380.

Candela, P. A. (1991). Physics of aqueous phase evolution in plutonic environments. American Mineralogist, 76, 1081-1091.

Candela, P. A. (2003). Ores in the Earth's crust. Treatise on Geochemistry, 3, 411-431.

Candela, P. A. and Piccoli, P. M. (2005). Magmatic processes in the development of porphyry-type ore systems. In: Hedenquist, J. W., Thompson, J. F. H., Goldfarb, R. J. \& Richards, J. P. (eds.) Economic Geology 100th Anniversary Volume. 25-37: Society of Economic Geologists, Littleton CO.

Carroll, M. R. and Rutherford, M. J. (1985). Sulfide and Sulfate Saturation in Hydrous Silicate Melts. Journal of Geophysical Research, 90, C601-C612.

Carroll, M. R. and Webster, J. D. (1994). Solubilities of sulfur, noble gases, nitrogen, chlorine, and fluorine in magmas. In: Carroll, M. R. \& Holloway, J. R. (eds.) Volatiles in Magmas. 30, 251279: Reviews in Mineralogy.

Catchpole, H., Kouzmanov, K., Fontbote, L., Guillong, M. and Heinrich, C. A. (2011). Fluid evolution in zoned Cordilleran polymetallic veins - Insights from microthermometry and LA-ICP-MS of fluid inclusions. Chemical Geology, 281, 293-304.

Cathles, L. M. (1981). Fluid flow and genesis of hydrothermal ore deposits. Economic Geology 75th Anniversary Volume. 424-457: Society of Economic Geologists, Littleton CO.

Cathles, L. M. (1997). Thermal aspects of ore formation. In: Barnes, H. L. (ed.) Geochemistry of Hydrothermal Ore Deposits. 3rd ed., 191-227: Wiley, J.

Cathles, L. M. and Shannon, R. (2007). How potassium silicate alteration suggests the formation of porphyry ore deposits begins with the nearly explosive but barren expulsion of large volumes of magmatic water. Earth and Planetary Science Letters, 262, 92-108.

Cathles, L. M. I. and Adams, J. J. (2005). Fluid flow and petroleum and mineral resources in the upper $(<20-\mathrm{km})$ continental crust. In: Hedenquist, J. W., Thompson, J. F. H., Goldfarb, R. J. \& Richards, J. P. (eds.) Economic Geology 100th Anniversary Volume. 77-110: Society of Economic Geologists, Littleton CO.

Cawthorn, R. G., Barnes, S. J., Ballhaus, C. and Malitch, K. N. (2005). Platinum group element, chromium, and vanadium deposits in mafic and ultramafic rocks. In: Hedenquist, J. W., Thompson, J. F. H., Goldfarb, R. J. \& Richards, J. P. (eds.) Economic Geology 100th Anniversary Volume. 215-249: Society of Economic Geologists, Littleton CO.

Černý, P., Blevin, P. L., Cuney, M. and London, D. (2005). Granite-related ore deposits. In: Hedenquist, J. W., Thompson, J. F. H., Goldfarb, R. J. \& Richards, J. P. (eds.) Economic Geology 100th Anniversary Volume. 337-370: Society of Economic Geologists, Littleton C0.

Cline, J. S. and Bodnar, R. J. (1991). Can economic porphyry copper mineralization be generated by a typical calc-alkaline melt? Journal of Geophysical Research, 96, 8113-8126.

Cline, J. S., Hofstra, A. H., Muntean, J. L., Tosdal, R. M. and Hickey, K. A. (2005). Carlin-type gold deposits in Nevada; critical geologic characteristics and viable models. In: Hedenquist, J. W., Thompson, J. F. H., Goldfarb, R. J. \& Richards, J. P. (eds.) Economic Geology 100th Anniversary Volume. 451-484: Society of Economic Geologists, Littleton CO.

Cloke, P. L. and Kesler, S. E. (1979). Halite Trend in Hydrothermal Solutions. Economic Geology, 74, 1823-1831.

Cloos, M. (2001). Bubbling magma chambers, cupolas, and porphyry copper deposits. International Geology Review, 43, 285-311.

Connors, K. A., Noble, D. C., Bussey, S. D. and Weiss, S. I. (1993). Initial gold contents of silicic volcanic rocks: Bearing on the behavior of gold in magmatic systems. Geology, 21, 937-940.

Coumou, D., Driesner, T. and Heinrich, C. A. (2008). The structure and dynamics of mid-ocean ridge hydrothermal systems. Science, 321, 1825-1828.

Courtillot, V. and Olson, P. (2007). Mantle plumes link magnetic superchrons to phanerozoic mass depletion events. Earth and Planetary Science Letters, 260, 495-504. 
Cox, D. P. and Singer, D. A. (1988). Distribution of gold in porphyry copper deposits. US Geological Survey, Open-File Reports, 88-46.

Cox, S. F. (2005). Coupling between deformation, fluid pressures, and fluid flow in ore-producing hydrothermal systems at depth in the crust. In: Hedenquist, J. W., Thompson, J. F. H., Goldfarb, R. J. \& Richards, J. P. (eds.) Economic Geology 100th Anniversary Volume. 39-75: Society of Economic Geologists, Littleton CO.

Cox, S. F. (2010). The application of failure mode diagrams for exploring the roles of fluid pressure and stress states in controlling styles of fracture-controlled permeability enhancement in faults and shear zones. Geofluids, 10, 217-233.

Cuney, M. (2010). Evolution of uranium fractionation processes through time: driving the secular variation of uranium deposit types. Economic Geology, 105, 553-569.

De Ronde, C. E. J., Hannington, M. D., Stoffers, P., Wright, I. C., Ditchburn, R. G., Reyes, A. G., Baker, E. T., Massoth, G. J., Lupton, J. E., Walker, S. L., Greene, R. R., Soong, C. W. R., Ishibashi, J., Lebon, G. T., Bray, C. J. and Resing, J. A. (2005). Evolution of a submarine magmatic-hydrothermal system: Brothers volcano, southern Kermadec arc, New Zealand. Economic Geology, 100, 1097-1133.

Deming, D. (1992). Catastrophic Release of Heat and Fluid-Flow in the Continental-Crust. Geology, 20, 83-86.

Dilles, J. H. (1987). The petrology of the Yerington Batholith, Nevada: evidence for the evolution of porphyry copper ore fluids. Economic Geology, 82, 1750-1789.

Dilles, J. H. and Einaudi, M. T. (1992). Wall-rock alteration and hydrothermal flow paths about the Ann-Mason porphyry copper deposit, Nevada - A 6km vertical reconstruction. Economic Geology, 87, 1963-2001.

Dolejs, D. and Wagner, T. (2008). Thermodynamic modeling of non-ideal mineral-fluid equilibria in the system Si-Al-Fe-Mg-Ca-Na-K-H-O-Cl at elevated temperatures and pressures: Implications for hydrothermal mass transfer in granitic rocks. Geochimica et Cosmochimica Acta, 72, 526-553.

Driesner, T. and Geiger, S. (2007). Numerical simulation of multiphase fluid flow in hydrothermal systems. In: Liebscher, A. \& Heinrich, C. A. (eds.) Fluid-Fluid Interactions. 65, 187-212: Reviews in Mineralogy.

Driesner, T. and Heinrich, C. A. (2007). The system H2O-NaCl. Part I: Correlation formulae for phase relations in temperature-pressure-composition space from 0 to 1000 degrees $C, 0$ to 5000 bar, and 0 to $1 \mathrm{X}-\mathrm{NaCl}$. Geochimica et Cosmochimica Acta, 71, 4880-4901.

Drummond, S. E. and Ohmoto, H. (1985). Chemical evolution and mineral deposition in boiling hydrothermal systems. Economic Geology, 87, 1963-2001.

Eastoe, C. J. (1982). Physics and chemistry of the hydrothermal system at the Panguna porphyry copper deposit, Bougainville, Papua New Guinea. Economic Geology, 77, 127-153.

Emsbo, P., Groves, D. I., Hofstra, A. H. and Bierlein, F. P. (2006). The giant Carlin gold province: a protracted interplay of orogenic, basinal, and hydrothermal processes above a lithospheric boundary. Mineralium Deposita, 41, 517-525.

Enders, M. S. and Saunders, C. (2011). Discovery, innovation, and learning in the mining business new ways forward for an old industry. SEG Newsletter, Society of Economic Geologists, 86, 122.

England, P. C. and Thompson, A. B. (1984). Pressure Temperature Time Paths of Regional Metamorphism .1. Heat-Transfer during the Evolution of Regions of Thickened ContinentalCrust. Journal of Petrology, 25, 894-928.

Eugster, H. P. and Hardie, L. A. (1975). Sedimentation in an ancient playa-lake complex - Wilkins Peak Member of the Green River Formation of Wyoming. Geological Society of America Bulletin, 86, 319-334.

Evans, K. F., Moriya, H., Niitsuma, H., Jones, R. H., Phillips, W. S., Genter, A., Sausse, J., Jung, R. and Baria, R. (2005). Microseismicity and permeability enhancement of hydrogeologic structures during massive fluid injections into granite at $3 \mathrm{~km}$ depth at the Soultz HDR site. Geophysical Journal International, 160, 388-412.

Fallick, A. E., Ashton, J. H., Boyce, A. J., Ellam, B. M. and Russell, M. J. (2001). Bacteria were responsible for the magnitude of the world-class hydrothermal base metal sulfide orebody at Navan Ireland. Economic Geology, 96, 885-890.

Fisher, A. T. (2005). Marine hydrogeology: recent accomplishments and future opportunities. Hydrogeology Journal, 13, 69-97. 
Fitch, W. I. (1997). Uranium, its impact on the national and global energy mix. USGS Report, Reston, 24 p.

Fournier, RO 1999, Hydrothermal processes related to movement of fluid from plastic into brittle rock in the magmatic-epithermal environment: Economic Geology, 94, 1193-1211.

Frakes, L. and Bolton, B. (1992). Effects of ocean chemistry, sea-level, and climate on the formation of primary sedimentary manganese ore-deposits. Economic Geology, 87, 1207-1217.

Frank, M. R., Candela, P. A., Piccoli, P. M. and Glascock, M. D. (2002). Gold solubility, speciation, and partitioning as a function of $\mathrm{HCl}$ in the brine-silicate melt-metallic gold system at 800 degrees C and 100 MPa. Geochimica et Cosmochimica Acta, 66, 3719-3732.

Frank, M. R., Simon, A. C., Pettke, T., Candela, P. A. and Piccoli, P. M. (2011). Gold and copper partitioning in magmatic-hydrothermal systems at 800 degrees $\mathrm{C}$ and $100 \mathrm{MPa}$. Geochimica et Cosmochimica Acta, 75, 2470-2482.

Franklin, J. M., Gibson, H. L., Jonasson, I. R. and Galley, A. G. (2005). Volcanogenic massive sulfide deposits. In: Hedenquist, J. W., Thompson, J. F. H., Goldfarb, R. J. \& Richards, J. P. (eds.) Economic Geology 100th Anniversary Volume. 523-560: Society of Economic Geologists, Littleton CO.

Freyssinet, P., Butt, C. R. M., Morris, R. C. and Piantone, P. (2005). Ore-forming processes related to lateritic weathering. In: Hedenquist, J. W., Thompson, J. F. H., Goldfarb, R. J. \& Richards, J. P. (eds.) Economic Geology 100th Anniversary Volume. 681-722: Society of Economic Geologists, Littleton CO.

Frimmel, H. E., Groves, D. I., Kirk, J., Ruiz, J., Chesley, J. and Minter, W. E. L. (2005). The formation and preservation of the Witwatersrand gold fields, the world's largest gold province. In: Hedenquist, J. W., Thompson, J. F. H., Goldfarb, R. J. \& Richards, J. P. (eds.) Economic Geology 100th Anniversary Volume. 769-797: Society of Economic Geologists, Littleton CO.

Frimmel, H. E. (2008). Earth's continental crustal gold endowment. Earth and Planetary Science Letters, 267, 45-55.

Fyfe, W. S., Price, N. J. and A.B., T. (1978). Fluids in the Earth's Crust: Their Significance in Metamorphic, Tectonic and Chemical Transport, Elsevier, 383 pp.

Gammons, C. H. and Williams-Jones, A. E. (1997). Chemical mobility of gold in the porphyryepithermal environment. Economic Geology, 92, 45-59.

Garnett, R. H. T. and Bassett, N. C. (2005). Placer deposits. In: Hedenquist, J. W., Thompson, J. F. H., Goldfarb, R. J. \& Richards, J. P. (eds.) Economic Geology 100th Anniversary Volume. 813-843: Society of Economic Geologists, Littleton CO.

Garven, G., Ge, S., Person, M. A. and Sverjensky, D. A. (1993). Genesis of stratabound ore deposits in the midcontinent basins of North America. 1. The role of regional groundwater flow. American Journal of Science, 293, 497-568.

German, C. R. and Von Damm, K. L. (2003). Hydrothermal systems. Treatise on Geochemistry: The Oceans. 6, 181-222: Elsevier.

Giggenbach, W. F. (1992). Magma degassing and mineral deposition in hydrothermal systems along convergent plate boundaries. Economic Geology, 87, 1927-1944.

Giggenbach, W. F. (1997). The origin and evolution of fluids in magmatic-hydrothermal systems. In: Barnes, H. L. (ed.) Geochemistry of Hydrothermal Ore Deposits. 3rd ed., 737-796: Wiley, J.

Goldfarb, R. J., Baker, T., Dubé, B., Groves, D. I., Hart, C. J. R. and Gosselin, P. (2005). Distribution, character, and genesis of gold deposits in metamorphic terranes. In: Hedenquist, J. W., Thompson, J. F. H., Goldfarb, R. J. \& Richards, J. P. (eds.) Economic Geology 100th Anniversary Volume. 407-450: Society of Economic Geologists, Littleton CO.

Graedel, T. E., Gordon, R. B. and Bertram, M. (2006). Metal stocks and sustainability. Proceedings of the National Academy of Sciences of the United States of America, 103, 1209-1214.

Groves, D. I. and Vielreicher, N. M. (2001). The Phalabowra (Palabora) carbonatite-hosted magnetitecopper sulfide deposit, South Africa: an end member of the iron-oxide copper-gold-rare earth element deposit group? Mineralium Deposita, 36, 189-194.

Groves, D. I., Condie, K. C., Goldfarb, R. J., Hronsky, J. M. A. and Vielreicher, R. M. (2005). Secular changes in global tectonic processes and their influence on the temporal distribution of goldbearing mineral deposits. Economic Geology, 100th Anniversary Special Paper, 100, 203-224.

Grupe, B., Becker, H. J. and Oebius, H. U. (2001). Geotechnical and sedimentological investigations of deep-sea sediments from a manganese nodule field of the Peru Basin. Deep-Sea Research Part II -Topical Studies in Oceanography, 48, 3593-3608. 
Gustafson, L. B. and Williams, N. (1981). Sediment-hosted stratiform deposits of copper, lead, and zinc. Economic Geology 75th Anniversary Volume. 139-178: Society of Economic Geologists, Littleton CO.

Halter, W. E., Williams-Jones, A. E. and Kontak, D. J. (1996). The role of greisenization in cassiterite precipitation at the East Kemptville tin deposit, Nova Scotia. Economic Geology, 91, 368-385.

Halter, W. E., Heinrich, C. A. and Pettke, T. (2005). Magma evolution and the formation of porphyry $\mathrm{Cu}-\mathrm{Au}$ ore fluids: evidence from silicate and sulfide melt inclusions. Mineralium Deposita, 39, 845-863.

Hannington, M. D., De Ronde, C. E. J. and Petersen, S. (2005). Sea floor tectonics and submarine hydrothermal systems. In: Hedenquist, J. W., Thompson, J. F. H., Goldfarb, R. J. \& Richards, J. P. (eds.) Economic Geology 100th Anniversary Volume. 111-141: Society of Economic Geologists, Littleton CO.

Hardie, L. A. and Eugster, H. P. (1970). The evolution of closed basin brins. Mineralogial Society of America Special Publication, 3, 273-290.

Harris, A. C., Kamenetsky, V. S., White, N. C., Van Achterbergh, E. and Ryan, C. G. (2003). Melt inclusions in veins: Linking magmas and porphyry $\mathrm{Cu}$ deposits. Science, 302, 2109-2111.

Hattori, K. H. and Keith, J. D. (2001). Contribution of mafic melt to porphyry copper mineralization: evidence from Mount Pinatubo, Philippines, and Bingham Canyon, Utah, USA. Mineralium Deposita, 36, 799-806.

Hayba, D. O. and Ingebritsen, S. E. (1997). Multiphase groundwater flow near cooling plutons. Journal of Geophysical Research, 102, 12235-12252.

Hecht, L. and Cuney, M. (2000). Hydrothermal alteration of monazite in the Precambrian crystalline basement of the Athabasca Basin (Saskatchewan, Canada): implications for the formation of unconformity-related uranium deposits. Mineralium Deposita, 35, 791-795.

Hedenquist, J. W. and Lowenstern, J. B. (1994). The role of magmas in the formation of hydrothermal ore deposits. Nature, 370, 519-527.

Hedenquist, J. W., Arribas, A. and Reynolds, T. J. (1998). Evolution of an intrusion-centered hydrothermal system: Far Southeast-Lepanto porphyry and epithermal $\mathrm{Cu}-\mathrm{Au}$ deposits, Philippines. Economic Geology, 93, 373-404.

Heinrich, C. A. (1990). The chemistry of hydrothermal tin-tungsten ore deposition. Economic Geology, 90, 705-729.

Heinrich, C. A., Bain, J. H. C., Mernagh, T. P., Wyborn, L. a. I., Andrew, A. S. and Waring, C. L. (1995). Fluid and mass transfer during metabasalt alteration and copper mineralization at Mount Isa, Australia. Economic Geology, 90, 705-730.

Heinrich, C. A., Günther, D., Audétat, A., Ulrich, T. and Frischknecht, R. (1999). Metal fractionation between magmatic brine and vapor, determined by microanalysis of fluid inclusions. Geology, 27, 755-758.

Heinrich, C. A., Driesner, T., Stefánsson, A. and Seward, T. M. (2004). Magmatic vapor contraction and the transport of gold from the porphyry environment to epithermal ore deposits. Geology, 32, 761-764.

Heinrich, C. A. (2006). From fluid inclusion microanalysis to large-scale hydrothermal mass transfer in the Earth's interior. Journal of Mineralogical and Petrological Sciences, 101, 110-117.

Hemley, J. J., Cygan, G. L., Fein, J. B., Robinson, G. R. and D'Angelo, W. M. (1992). Hydrothermal oreforming processes in the light of studies in rock-buffered systems: I. Iron-copper-zinc-lead sulfide solubility relations. Economic Geology, 87, 1-22.

Henley, R. W. and Mcnabb, A. (1978). Magmatic vapor plumes and ground-water interaction in porphyry copper emplacement. Economic Geology, 73, 1-20.

Henley, R. W. and Berger, B. R. (2000). Self-ordering and complexity in epizonal mineral deposits. Annual Review of Earth and Planetary Sciences, 28, 669-719.

Hennings, S. K., Wagner, T., Heinrich, C. A. and Ulmer, P. (2012). Fluid evolution of the Monte Mattoni mafic complex, Adamello batholith, northern Italy: constraints from LA-ICPMS analysis of fluid inclusions and thermodynamic modeling. Journal of Petrology, in review.

Henry, A. L., Anderson, G. M. and Heroux, Y. (1992). Alteration of organic matter in the Viburnum Trend lead-zinc district of Southeastern Missouri. Economic Geology, 87, 288-309.

Hill, D. P., Pollitz, F. and Newhall, C. (2002). Earthquake-volcano interactions. Physics Today, 55, 4147.

Hitzman, M., Kirkham, R., Broughton, D., Thorson, J. and Selley, D. (2005). The sediment-hosted stratiform copper ore system. In: Hedenquist, J. W., Thompson, J. F. H., Goldfarb, R. J. \& 
Richards, J. P. (eds.) Economic Geology 100th Anniversary Volume. 609-642: Society of Economic Geologists, Littleton CO.

Holland, H. D. (2005). 100th Anniversary Special Paper: Sedimentary mineral deposits and the evolution of earth's near-surface environments. Economic Geology, 100, 1489-1509.

Holland, T. J. B. and Powell, R. (1998). An internally consistent thermodynamic data set for phases of petrological interest. Journal of Metamorphic Geology, 16, 309-343.

Huenges, E., Erzinger, J., Kuck, J., Engeser, B. and Kessels, W. (1997). The permeable crust: Geohydraulic properties down to $9101 \mathrm{~m}$ depth. Journal of Geophysical Research-Solid Earth, 102, 18255-18265.

Ingebritsen, S. E., Sanford, S. and Neuzil, C. (2006). Groundwater in Geologic Processes, 2. ed., Cambridge University Press, 536 pp.

Ingebritsen, S. E., Geiger, S., Hurwitz, S. and Driesner, T. (2010). Numerical Simulation of Magmatic Hydrothermal Systems. Reviews of Geophysics, 48, 1-33.

Ingebritsen, S. E. and Manning, C. E. (2010). Permeability of the continental crust: dynamic variations inferred from seismicity and metamorphism. Geofluids, 10, 193-205.

Ingebritsen, S. E. and Appold, M. S. (2011). The physical hydrology of ore deposits. Economic Geology, in review.

Irvine, T. N. (1977). Origin of chromitite layers in Muskox intrusion and other stratiform intrusions new interpretation. Geology, 5, 273-277.

Jones, H. D. and Kesler, S. E. (1992). Fluid Inclusion Gas Chemistry in East Tennessee Mississippi Valley-Type Districts - Evidence for Immiscibility and Implications for Depositional Mechanisms. Geochimica et Cosmochimica Acta, 56, 137-154.

Jugo, P. J., Candela, P. A. and Piccoli, P. M. (1999). Magmatic sulfides and Au : Cu ratios in porphyry deposits: an experimental study of copper and gold partitioning at 850 degrees $\mathrm{C}, 100 \mathrm{MPa}$ in a haplogranitic melt - pyrrhotite - intermediate solid solution - gold metal assemblage, at gas saturation. Lithos, 46, 573-589.

Kay, S. M. and Mpodozis, C. (2002). Magmatism as a probe to the Neogene shallowing of the Nazca plate beneath the modern Chilean flat-slab. Journal of South American Earth Sciences, 15, 3957.

Kelley, K. A. and Cottrell, E. (2009). Water and the oxidation state of subduction zone magmas. Science, 325, 605-607.

Kesler, S. E. (1994). Mineral Resources, Economics and the Environment, New York, McMillan, 391 pp.

Kesler, S. E., Riciputi, L. C. and Ye, Z. J. (2005). Evidence for a magmatic origin for Carlin-type gold deposits: isotopic composition of sulfur in the Betze-Post-Screamer deposit, Nevada, USA. Mineralium Deposita, 40, 127-136.

Kesler, S. E. and Wilkinson, B. H. (2008). Earth's copper resources estimated from tectonic diffusion of porphyry copper deposits. Geology, 36, 255-258.

Kesler, S. E. and Wilkinson, B. H. (2009). Resources of gold in Phanerozoic epithermal deposits. Economic Geology, 104, 623-633.

Kharaka, Y. K., Maest, A. S., Carothers, W. M., Law, L. M., Lamothe, P. J., and Fries, T. L., 1987. Geochemistry of metal-rich brines from central Mississippi Salt Dome basin, U.S.A. Appl. Geochem. 2, 543-561.

Knight, C. L. (1957). Ore genesis; the source bed concept. Economic Geology, 52, 808-817.

Koděra, P., Lexa, J., Heinrich, C. A., Waelle, M., and Fallick, A. E., 2011, Au mineralisation at Biely Vrch deposit (W Carpathians, Slovakia): example of a very shallow porphyry system: 11th Biennial SGA Meeting, Antofagasta, Extended Abstract, p. 100-103.

Kostova, B., Pettke, T., Driesner, T., Petrov, P. and Heinrich, C. A. (2004). LA ICP-MS study of fluid inclusions in quartz from the Yuzhna Petrovitsa deposit, Madan ore field, Bulgaria. Schweizerische Mineralogische und Petrographische Mitteilungen, 84, 25-36.

Koziy, L., Bull, S., Large, R. and Selley, D. (2009). Salt as a fluid driver, and basement as a metal source, for stratiform sediment-hosted copper deposits. Geology, 37, 1107-1110.

Krahulec, K. A. (2010). Production history of the Bingham mining district, Salt Lake county, Utah. In: Krahulec, K. A. \& Schroeder, K. (eds.) Tops and bottoms of porphyry copper deposits: The Bingham and southwest Tintic districts, Utah. 41, 25-33: Guidebook Series of the Society of Economic Geologists.

Landtwing, M. R., Furrer, C., Redmond, P. B., Pettke, T., Guillong, M. and Heinrich, C. A. (2010). The Bingham Canyon porphyry $\mathrm{Cu}-\mathrm{Mo}-\mathrm{Au}$ deposit. III. Zoned copper - gold ore deposition by magmatic vapor expansion. Economic Geology, 105, 91-118. 
Large, R. R. (1992). Australian volcanic-hosted massive sulfide deposits: features, styles, and genetic models. Economic Geology, 87, 471-510.

Lasky, S., G. (1950). How tonnage and grade relations help predict ore reserves. Engineering and Mining Journal 151, 81-85.

Law, J. D. M. and Phillips, G. N. (2005). Hydrothermal replacement model for Witwatersrand gold. In: Hedenquist, J. W., Thompson, J. F. H., Goldfarb, R. J. \& Richards, J. P. (eds.) Economic Geology 100th Anniversary Volume. 799-811: Society of Economic Geologists, Littleton CO.

Leach, D. L., Sangster, D. F., Kelley, K. D., Large, R. R., Garven, G., Allen, C. R., Gutzmer, J. and Walters, S. (2005a). Sediment-hosted lead-zinc deposits; a global perspective. In: Hedenquist, J. W., Thompson, J. F. H., Goldfarb, R. J. \& Richards, J. P. (eds.) Economic Geology 100th Anniversary Volume. 561-607: Society of Economic Geologists, Littleton CO.

Leach, D. L., Sangster, D. F., Kelley, K. D., Large, R. R., Garven, G., Allen, C. R., Gutzmer, J. and Walters, S. (2005b). Sediment-hosted lead-zinc deposits; a global perspective. Economic Geology 100th Anniversary Volume, 561-607.

Lehmann, B., Ishihara, S., Michel, H., Miller, J., Rapela, C., Sanchez, A., Tistl, M. and Winkelmann, L. (1990). The Bolivian tin province and regional tin distribution in the Central Andes - a reassessment. Economic Geology, 85, 1044-1058.

Lesher, C. M., Lee, R. F., Groves, D. I., Bickle, M. J. and Donaldson, M. J. (1981). Geochemistry of komatiites from Kambalda, Western Australia. 1. Chalcophile element depletion - a consequence of sulfide liquid separation from komatiitic magmas. Economic Geology, 76, 1714-1728.

Li, C. S., Ripley, E. M. and Naldrett, A. J. (2009a). A new genetic model for the giant Ni-Cu-PGE sulfide deposits associated with the Siberian flood basalts. Economic Geology, 104, 291-301.

Li, Y., Audétat, A., Lerchbaumer, L. and Xiong, X. L. (2009b). Rapid Na, Cu exchange between synthetic fluid inclusions and external aqueous solutions: evidence from LA-ICP-MS analysis. Geofluids, 9, 321-329.

Liebscher, A. and Heinrich, C. A. (2007). Fluid-fluid interactions in the earth's lithosphere. Reviews in Mineralogy and Geochemistry. 65, 1-13.

Lowenstern, J. B. (2001). Carbon dioxide in magmas and implications for hydrothermal systems. Mineralium Deposita, 36, 490-502.

Mahara, Y., Habermehl, M. A., Hasegawa, T., Nakata, K., Ransley, T. R., Hatano, T., Mizuochi, Y., Kobayashi, H., Ninomiya, A., Senior, B. R., Yasuda, H. and Ohta, T. (2009). Groundwater dating by estimation of groundwater flow velocity and dissolved He-4 accumulation rate calibrated by Cl-36 in the Great Artesian Basin, Australia. Earth and Planetary Science Letters, 287, 4356.

Maier, W. D. and Groves, D. I. (2011). Temporal and spatial controls on the formation of magmatic PGE and Ni-Cu deposits. Mineralium Deposita, 46, 841-857.

Montoya, J. W. and Hemley, J. J. (1975). Activity relations and stabilities in alkali feldspar and mica alteration reactions. Economic Geology, 70, 577-583.

Mungall, J. E. (2002). Roasting the mantle: Slab melting and the genesis of major Au and Au-rich Cu deposits. Geology, 30, 915-918.

Muntean, J. L. and Einaudi, M. T. (2000). Porphyry gold deposits of the Refugio district, Maricunga belt, northern Chile. Economic Geology, 95, 1445-1472.

Muntean, J. L., Cline, J. S., Simon, A. C. and Longo, A. A. (2011). Magmatic-hydrothermal origin of Nevada's Carlin-type gold deposits. Nature Geoscience, 4, 122-127.

Murakami, H., Seo, J. H. and Heinrich, C. A. (2010). The relation between Cu/Au ratio and formation depth of porphyry-style $\mathrm{Cu}-\mathrm{Au}$ +/- Mo deposits. Mineralium Deposita, 45, 11-21.

Mustard, R., Ulrich, T., Kamenetsky, V. S. and Mernagh, T. (2006). Gold and metal enrichment in natural granitic melts during fractional crystallization. Geology, 34, 85-88.

Nagaseki, H. and Hayashi, K. I. (2008). Experimental study of the behavior of copper and zinc in a boiling hydrothermal system. Geology, 36, 27-30.

Naldrett, A. J. (2010). Secular variation of magmatic sulfide deposits and their source magmas. Economic Geology, 105, 669-688.

Ohmoto, H. (1986). Stable isotope geochemistry of ore deposits. In: Valley, J. W., Taylor, H. P., Jr. \& O, N. J. R. (eds.) Stable isotopes in high temperature geological processes. Reviews in Mineralogy. 16, 491-559.

Pettke, T., Oberli, F. and Heinrich, C. A. (2010). The magma and metal source of giant porphyry-type ore deposits, based on lead isotope microanalysis of individual fluid inclusions. Earth and Planetary Science Letters, 296, 267-277. 
Phillips, G. N. and Groves, D. I. (1983). The nature of Archean gold-bearing fluids as deduced from gold deposits of Western Australia. Journal of the Geological Society of Australia, 30, 25-39.

Plumlee, G. S., Leach, D. L., Hofstra, A. H., Landis, G. P., Rowan, E. L. and Viets, J. G. (1994). Chemical reaction path modeling of ore deposition in Mississippi Valley-type $\mathrm{Pb}-\mathrm{Zn}$ deposits of the Ozark Region, United-States Midcontinent. Economic Geology, 89, 1361-1383.

Pohl, W. L. (2011). Economic Geology, Principles and Practice, Wiley, 680 pp.

Pokrovski, G. S., Borisova, A. Y. and Harrichoury, J. C. (2008). The effect of sulfur on vapor-liquid fractionation of metals in hydrothermal systems. Earth and Planetary Science Letters, 266, 345-362.

Reed, M. H. (1997). Hydrothermal alteration and its relationship to ore fluid composition. In: Barnes, H. L. (ed.) Geochemistry of Hydrothermal Ore Deposits. 3rd ed., 303-365: Wiley, J.

Reilly, M. J. and Flemings, P. B. (2010). Deep pore pressures and seafloor venting in the Auger Basin, Gulf of Mexico. Basin Research, 22, 380-397.

Richards, J. P. (2003). Tectono-magmatic precursors for porphyry $\mathrm{Cu}-(\mathrm{Mo}-\mathrm{Au})$ deposit formation. Economic Geology, 98, 1515-1533.

Richards, J. P. (2011a). Magmatic to hydrothermal metal fluxes in convergent and collided margins. Ore Geology Reviews, 40, 1-26.

Richards, J. P. (2011b). High Sr/Y Arc Magmas and Porphyry Cu +/- Mo +/- Au Deposits: Just Add Water. Economic Geology, 106, 1075-1081.

Ridley, J. (1993). The Relations between mean rock stress and fluid-flow in the crust - with reference to vein-style and lode-style gold deposits. Ore Geology Reviews, 8, 23-37.

Ridley, J., Mikucki, E. J. and Groves, D. I. (1996). Archean lode-gold deposits: Fluid flow and chemical evolution in vertically extensive hydrothermal systems. Ore Geology Reviews, 10, 279-293.

Ridley, J. and Mengler, F. (2000). Lithological and structural controls on the form and setting of vein stockwork orebodies at the Mount Charlotte gold deposit, Kalgoorlie. Economic Geology, 95, 85-98.

Rimstidt, J. D. (1997). Gangue mineral transport and deposition. In: Barnes, H. L. (ed.) Geochemistry of Hydrothermal Ore Deposits. 3rd ed., 487-515: Wiley, J.

Robb, L. (2004). Introduction to Ore-Forming Processes, Wiley-VCH, 384 pp.

Rohrlach, B. D. and Loucks, R. R. (2005). Multi-million-year cyclic ramp-up of volatiles in a lowercrustal magma reservoir trapped below the Tampakan copper - gold deposit by Mio-Pliocene crustal compression in the southern Philippines. In: Porter, T. M. (ed.) Super porphyry copper and gold deposits: A global perspective. 2, 1-43: PGC Publishing (Adelaide).

Rojstaczer, S. A., Ingebritsen, S. E. and Hayba, D. O. (2008). Permeability of continental crust influenced by internal and external forcing. Geofluids, 8, 128-139.

Rowan, E. L., Goldhaber, M. B. and Hatch, J. R. (2002). Regional fluid flow as a factor in the thermal history of the Illinois basin: Constraints from fluid inclusions and the maturity of Pennsylvanian coals. AAPG Bulletin, 86, 257-277.

Rudnick, R. L. and Gao, S. (2003). Composition of the Continental Crust. Treatise on Geochemistry. 3, 1-64: Elsevier.

Rusk, B. G., Reed, M. H. and Dilles, J. H. (2008). Fluid inclusion evidence for magmatic-hydrothermal fluid evolution in the porphyry copper-molybdenum deposit at Butte, Montana. Economic Geology, 103, 307-334.

Russell, M. J., Solomon, M. and Walshe, J. L. (1981). The genesis of sediment-hosted, exhalative zinc + lead deposits. Mineralium Deposita, 16, 113-127.

Russell, M. J., Hall, A. J., Boyce, A. J. and Fallick, A. E. (2005). 100th Anniversary Special Paper: On hydrothermal convection systems and the emergence of life. Economic Geology, 100, 419438.

Scott, S. D. (1997). Submarine hydrothermal systems and deposits. In: Barnes, H. L. (ed.) Geochemistry of Hydrothermal Ore Deposits. 3rd ed., 797-875: Wiley, J.

Seo, J. H., Guillong, M. and Heinrich, C. A. (2009). The role of sulfur in the formation of magmatichydrothermal copper-gold deposits. Earth and Planetary Science Letters, 282, 323-328.

Seward, T. M. (1984). The formation of lead(II) chloride complexes to $300^{\circ} \mathrm{C}$ - a spectrophotometric study. Geochimica et Cosmochimica Acta, 48, 121-134.

Seward, T. M. and Barnes, H. L. (1997). Metal transport by hydrothermal ore fluids. In: Barnes, H. L. (ed.) Geochemistry of Hydrothermal Ore Deposits. 3rd ed., 435-486: Wiley, J.

Shen, W. and Zhao, P. D. (2002). Theoretical study of statistical fractal model with applications to mineral resource prediction. Computers \& Geosciences, 28, 369-376. 
Shinohara, H., Kazahaya, K. and Lowenstern, J. B. (1995). Volatile transport in a convecting magma column - implications for porphyry Mo mineralization. Geology, 23, 1091-1094.

Sibson, R. H. (1992). Implications of fault-valve behavior for rupture nucleation and recurrence. Tectonophysics, 211, 283-293.

Sillitoe, R. H. (2005). Supergene oxidized and enriched porphyry copper and related deposits. In: Hedenquist, J. W., Thompson, J. F. H., Goldfarb, R. J. \& Richards, J. P. (eds.) Economic Geology 100th Anniversary Volume. 723-768: Society of Economic Geologists, Littleton CO.

Sillitoe, R. H. (2010). Porphyry copper systems. Economic Geology (Invited Special Paper), 105, 3-41.

Simmons, S. F., White, N. C. and John, D. A. (2005). Geological characteristics of epithermal precious and base metal deposits. In: Hedenquist, J. W., Thompson, J. F. H., Goldfarb, R. J. \& Richards, J. P. (eds.) Economic Geology 100th Anniversary Volume. 455-522: Society of Economic Geologists, Littleton CO.

Simmons, S. F. and Brown, K. L. (2007). The flux of gold and related metals through a volcanic arc, Taupo Volcanic Zone, New Zealand. Geology, 35, 1099-1102.

Simon, G., Kesler, S. E. and Chryssoulis, S. (1999). Geochemistry and textures of gold-bearing arsenian pyrite, Twin Creeks, Nevada: Implications for deposition of gold in Carlin- type deposits. Economic Geology, 94, 405-421.

Simon, G., Kesler, S. E., Essene, E. J. and Chryssoulis, S. L. (2000). Gold in porphyry copper deposits: Experimental determination of the distribution of gold in the $\mathrm{Cu}-\mathrm{Fe}-\mathrm{S}$ system at $400^{\circ}$ to $700^{\circ}$ C. Economic Geology, 95, 259-270.

Singer, D. A. (1995). World-Class Base and Precious-Metal Deposits - a Quantitative-Analysis. Economic Geology, 90, 88-104.

Singer, D. A., Berger, V. I., Menzie, W. D. and Berger, B. R. (2005). Porphyry copper deposit density. Economic Geology, 100, 491-514.

Singer, D. A. (2010). Progress in integrated quantitative mineral resource assessments. Ore Geology Reviews, 38, 242-250.

Skinner, B. J. (1997). Hydrothermal metal deposits: What we do and don't know. In: Barnes, H. L. (ed.) Geochemistry of Hydrothermal Ore Deposits. 3rd ed., 1-29: Wiley, J.

Solomon, M. and Walshe, J. L. (1979). Formation of massive sulfide deposits on the sea-floor. Economic Geology, 74, 797-813.

Solomon, M. and Quesada, C. (2003). Zn-Pb-Cu massive sulfide deposits: Brine-pool types occur in collisional orogens, black smoker types occur in backarc and/or arc basins. Geology, 31, 1029-1032.

Spycher, N. F. and Reed, M. H. (1989). Evolution of a Broadlands-type epithermal ore fluid along alternative P-T paths - implications for the transport and deposition of base, precious, and volatile metals. Economic Geology, 84, 328-359.

Stanton, R. L. (1955). Lower Paleozoic mineralisation near Bathurst, New South Wales. Economic Geology, 50, 681-714.

Stefánsson, A. and Seward, T. M. (2004). Gold(I) complexing in aqueous sulphide solutions to $500^{\circ} \mathrm{C}$ at 500 bar. Geochimica et Cosmochimica Acta, 68, 4121-4143.

Stoffell, B., Appold, M. S., Wilkinson, J. J., Mcclean, N. A. and Jeffries, T. E. (2008). Geochemistry and evolution of Mississippi Valley-type mineralizing brines from the Tri-State and Northern Arkansas districts determined by LA-ICP-MS microanalysis of fluid inclusions. Economic Geology, 103, 1411-1435.

Stowe, C. W. (1994). Composition and tectonic settings of chromite deposits through time. Economic Geology and the Bulletin of the Society of Economic Geologists, 89, 528-546.

Sun, W. D., Arculus, R. J., Kamenetsky, V. S. and Binns, R. A. (2004). Release of gold-bearing fluids in convergent margin magmas prompted by magnetite crystallization. Nature, 431, 975-978.

Sverjensky, D. A. (1986). Genesis of Mississippi Vallye Type lead - zinc deposits. Annual Review of Earth and Planetary Sciences, 14, 177-199.

Sverjensky, D. A., Shock, E. L. and Helgeson, H. C. (1997). Prediction of the thermodynamic properties of aqueous metal complexes to 1000 degrees C and $5 \mathrm{~kb}$. Geochimica Et Cosmochimica Acta, 61, 1359-1412.

Taylor, S. R. and Mclennan, S. M. (1995). The geochemical evolution of the continental-crust. Reviews of Geophysics, 33, 241-265.

Thom, J. and Anderson, G. M. (2008). The role of thermochemical sulfate reduction in the origin of Mississippi Valley-type deposits. I. Experimental results. Geofluids, 8, 16-26.

Tilton, J. E. and Lagos, G. (2007). Assessing the long-run availability of copper. Resources Policy, 32, 19-23. 
Tornos, F. and Heinrich, C. A. (2008). Shale basins, sulfur-deficient ore brines and the formation of exhalative base metal deposits. Chemical Geology, 247, 195-207.

Townend, J. and Zoback, M. D. (2000). How faulting keeps the crust strong. Geology, 28, 399-402.

Ulrich, T., Günther, D. and Heinrich, C. A. (1999). Gold concentrations of magmatic brines and the metal budget of porphyry copper deposits. Nature, 399, 676-679.

Ulrich, T. and Heinrich, C. A. (2002). Geology and alteration geochemistry of the porphyry $\mathrm{Cu}-\mathrm{Au}$ deposit at Bajo de la Alumbrera, Argentina. Economic Geology, 97, 1863-1888.

Vila, T. and Sillitoe, R. H. (1991). Gold-rich porphyry systems in the Maricunga belt, Northern Chile. Economic Geology, 86, 1238-1260.

Von Damm, K. L. (2005). Evolution of the hydrothermal system at the East Pacific Rise $9^{\circ} 50^{\prime} \mathrm{N}$ : Geochemical evidence for changes in the upper oceanic crust. In: German, C. R., Lin, J. \& Parson, L. M. (eds.) Mid-ocean Ridges: Hydrothermal Interactions between the Lithosphere and Oceans. 148, 285-304: Geophysical Monograph.

Von Quadt, A., Erni, M., Martinek, K., Moll, M., Peytcheva, I. and Heinrich, C. A. (2011). Zircon crystallization and the lifetimes of ore-forming magmatic-hydrothermal systems. Geology, 39, 731-734.

Wall, V. J., Graupner, T., Yantsen, V., Seltmann, R. and Hall, A. J. (2004). Muruntau, Uzbekistan: a giant thermal aureole gold (TAG) system. Extended Abstract, SEG Conference "Predictive Mineral Discovery under Cover", Perth.

Watson, E. B. and Baxter, E. F. (2007). Diffusion in solid-Earth systems. Earth and Planetary Science Letters, 253, 307-327.

Wilde, A. R. and Wall, V. J. (1987). Geology of the Nabarlek Uranium Deposit, Northern-Territory, Australia. Economic Geology, 82, 1152-1168.

Wilkinson, B. H. and Kesler, S. E. (2009). Quantitative identification of metallogenic epochs and provinces: application to Phanerozoic porphyry copper deposits. Economic Geology, 104, 607-622.

Wilkinson, J. J., Everett, C. E., Boyce, A. J., Gleeson, S. A. and Rye, D. M. (2005). Intracratonic crustal seawater circulation and the genesis of subseafloor zinc-lead mineralization in the Irish orefield. Geology, 33, 805-808.

Wilkinson, J. J., Stoffell, B., Wilkinson, C. C., Jeffries, T. E. and Appold, M. S. (2009). Anomalously metalrich fluids form hydrothermal ore deposits. Science, 323, 764-767.

Williams, A. E. and Mckibben, M. A. (1989). A brine interface in the Salton Sea geothermal system, California - fluid geochemical and isotopic characteristics. Geochimica Et Cosmochimica Acta, 53, 1905-1920.

Williams, P. J., Barton, M. D., Johnson, D. A., Fontbote, L., De Haller, A., Mark, G., Oliver, N. H. S. and Marschik, R. (2005). Iron oxide copper-gold deposits; geology, space-time distribution, and possible modes of origin. In: Hedenquist, J. W., Thompson, J. F. H., Goldfarb, R. J. \& Richards, J. P. (eds.) Economic Geology 100th Anniversary Volume. 371-405: Society of Economic Geologists, Littleton CO.

Williams-Jones, A. E. and Heinrich, C. A. (2005). 100th Anniversary Special Paper: Vapor transport of metals and the formation of magmatic-hydrothermal ore deposits. Economic Geology, 100, 1287-1312.

Yang, K. H. and Scott, S. D. (1996). Possible contribution of a metal-rich magmatic fluid to a sea-floor hydrothermal system. Nature, 383, 420-423.

Yardley, B. W. D. (2005). 100th Anniversary Special Paper: Metal concentrations in crustal fluids and their relationship to ore formation. Economic Geology, 100, 613-632.

Zajacz, Z. and Halter, W. (2009). Copper transport by high temperature, sulfur-rich magmatic vapor: Evidence from silicate melt and vapor inclusions in a basaltic andesite from the Villarrica volcano (Chile). Earth and Planetary Science Letters, 282, 115-121.

Zajacz, Z., Hanley, J. J., Heinrich, C. A., Halter, W. E. and Guillong, M. (2009). Diffusive reequilibration of quartz-hosted silicate melt and fluid inclusions: Are all metal concentrations unmodified? Geochimica et Cosmochimica Acta, 73, 3013-3027.

Zajacz, Z., Seo, J. H., Candela, P. A., Piccoli, P. M., Heinrich, C. A. and Guillong, M. (2010). Alkali metals control the release of gold from volatile-rich magmas. Earth and Planetary Science Letters, 297, 50-56. 